\title{
From Thorium to Plutonium: Trends in Actinide (IV) Chloride Structural Chemistry
}

Jennifer N. Wacker, ${ }^{\dagger}$ Sae Young Han,,$^{\dagger}$ Aphra V. Murray, ${ }^{\dagger}$ Nicole A. Vanagas ${ }^{\dagger}$ Jeffery A. Bertke, ${ }^{\dagger}$ Joseph M. Sperling, ${ }^{*}$ Robert G. Surbella III, ${ }^{\S}$ Karah E. Knope ${ }^{\dagger, *}$

$\uparrow$ Department of Chemistry, Georgetown University, $37^{\text {th }}$ and O Streets NW, Washington, D.C. 20057, USA; \$ Department of Chemistry and Biochemistry, Florida State University, Tallahassee, Florida 32306, USA; § Pacific Northwest National Laboratory, 902 Battelle Boulevard, Richland, Washington 99354, USA

\section{ELECTRONIC SUPPLEMENTAL INFORMATION}

\section{TABLE OF CONTENTS}

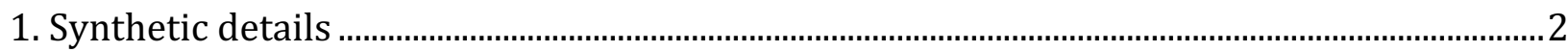

2. Crystallographic refinement details ........................................................................................... 7

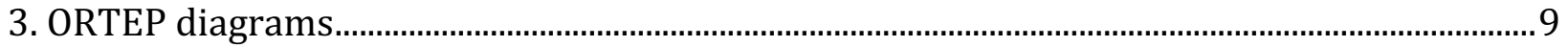

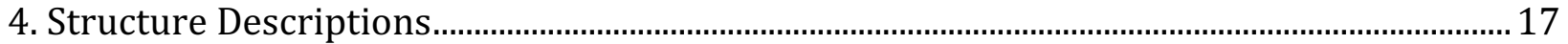

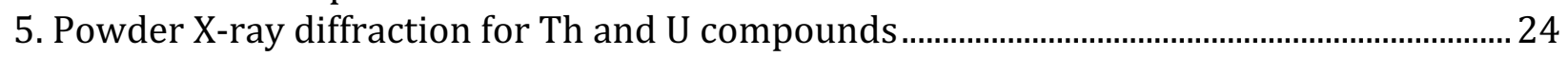

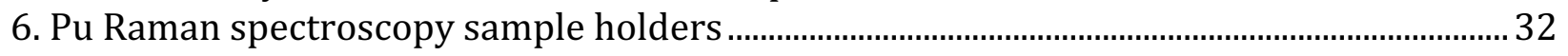

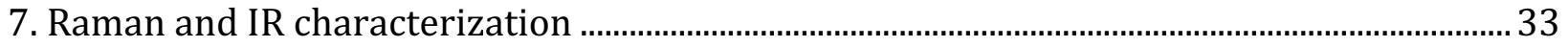

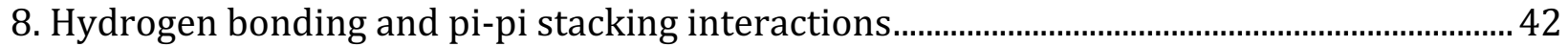

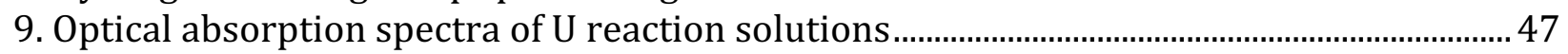

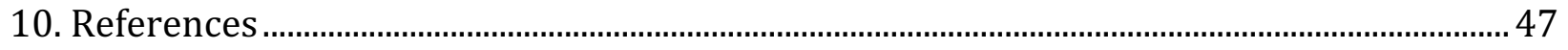




\section{Synthetic details}

Caution! ${ }^{232} \mathrm{Th}\left(t_{1 / 2}=1.41 \times 10^{10} \mathrm{yrs}\right),{ }^{238} \mathrm{U}\left(t_{1 / 2}=4.47 \times 10^{9} \mathrm{yrs}\right)$, and ${ }^{239} \mathrm{Pu}\left(t_{1 / 2}=2.41 \times 10^{4} \mathrm{yrs}\right)$ pose health risks due to their toxicity and radiological properties. As such, experiments were performed in facilities designed for the handling of radionuclides. ${ }^{232} \mathrm{Th}$ and ${ }^{238} \mathrm{U}$ experiments were conducted in accordance with institutional radiological safety procedures. All evaporations were carried out under a nitrogen atmosphere in a radiological area to prevent oxidation of $U(I V) ; T h(I V)$ reactions also were performed under a nitrogen atmosphere for consistency with $U$ experiments. ${ }^{239} \mathrm{Pu}$ experiments followed stricter guidelines due to increased risks when dealing with transuranic radionuclides. Preparation of the ${ }^{239} \mathrm{Pu}(\mathrm{IV}) / \mathrm{HCl}$ stock solution, experimental reactions, and evaporation of the reaction solutions were all carried out in a negative-pressure radiological glovebox equipped with HEPA filters. Sample for structure determination and spectroscopic studies were prepared in radiological fume hoods utilizing Krytox grease to coat the crystals in order to limit dispersal of the transuranic materials.

\section{Th compounds}

$\left[\mathrm{Th}\left(\mathrm{H}_{2} \mathrm{O}\right)_{6} \mathrm{Cl}_{3}\right] \mathrm{Cl} \cdot(3-\mathrm{ClPyH} \cdot \mathrm{Cl})(\boldsymbol{T h}-\mathbf{1})$. An aqueous solution of Th(IV) in $\mathrm{HCl}$ was prepared in a $3 \mathrm{~mL}$ glass shell vial by dissolving $\mathrm{ThCl}_{4}(0.049 \mathrm{~g}, 0.132 \mathrm{mmol})$ into $3 \mathrm{M} \mathrm{HCl}(0.5 \mathrm{~mL}) .3$ chloropyridine $(12.6 \mu \mathrm{L}, 0.132 \mathrm{mmol})$ was added and the solution was left to evaporate under a nitrogen atmosphere. After approximately 7 days, large colorless crystals formed. IR $\left(\mathrm{cm}^{-1}\right): 431$ (w), $461(\mathrm{w}), 469(\mathrm{~m}), 620(\mathrm{w}), 669(\mathrm{~s}), 670(\mathrm{~s}), 728(\mathrm{~s}), 748(\mathrm{w}), 792(\mathrm{~s}), 878(\mathrm{w}), 942(\mathrm{w}), 987$ (w), $1012(\mathrm{w}), 1029(\mathrm{w}), 1042(\mathrm{w}), 1070(\mathrm{w}), 1106(\mathrm{~m}), 1122(\mathrm{~m}), 1181(\mathrm{~m}), 1255(\mathrm{~m}), 1283(\mathrm{w}$, b), $1310(\mathrm{w}), 1331$ (m), 1353 (w), 1456 (s), 1520 (s, sh), 1525 (s, sh), 1532 (s), 1602 (s, b), 1621 (m), $1627(\mathrm{~m}), 1635(\mathrm{~m}), 1638(\mathrm{w}), 2856(\mathrm{~m}), 2894(\mathrm{~m}), 2919(\mathrm{~m}), 3035(\mathrm{~m}, \mathrm{sh}), 3049(\mathrm{~s}), 3067$ (m, b), 3106 (m), 3113 (m, sh), 3153 (s, b), 3207 (s, b), 3256 (s, b). Raman (cm $\left.{ }^{-1}\right): 119(\mathrm{~s}), 210$ (m, sh), $227(\mathrm{~s}), 300(\mathrm{w}), 400(\mathrm{w}), 428(\mathrm{w}), 620(\mathrm{w}), 729(\mathrm{~m}), 791(\mathrm{w}), 940(\mathrm{w}), 1010(\mathrm{w}), 1029$ (s), 1040 (vs), 1070 (w, b), 1106 (m), 1119 (m), 1176 (m), 1253 (m), 1573 (w), 1602 (m, b), $1621(\mathrm{~m}), 3105(\mathrm{~m}), 3444$ (w, b).

$\left[\mathrm{Th}\left(\mathrm{H}_{2} \mathrm{O}\right)_{5} \mathrm{Cl}_{4}\right] \cdot\left(\mathrm{H}_{2}\right.$ bipy $\left.\cdot 2 \mathrm{Cl}\right) \cdot \mathrm{H}_{2} \mathrm{O}$ (Th-2). An aqueous solution of $\mathrm{Th}(\mathrm{IV})$ in $\mathrm{HCl}$ was prepared in a $3 \mathrm{~mL}$ glass shell vial by dissolving $\mathrm{ThCl}_{4}(0.049 \mathrm{~g}, 0.132 \mathrm{mmol})$ into $3 \mathrm{M} \mathrm{HCl}(0.5 \mathrm{~mL})$. 4,4bipyridine $(0.022 \mathrm{~g}, 0.140 \mathrm{mmol})$ was added and the solution was left to evaporate under a nitrogen atmosphere. After approximately 3 days, large colorless crystals were present. IR and Raman details: refer to Table S2.

$\left[\mathrm{Th}\left(\mathrm{H}_{2} \mathrm{O}\right)_{4} \mathrm{Cl}_{4}\right] \cdot 2(4-\mathrm{OHPyH} \cdot \mathrm{Cl})(\mathbf{T h}-3)$. An aqueous solution of Th(IV) in $\mathrm{HCl}$ was prepared in a $3 \mathrm{~mL}$ glass shell vial by dissolving $\mathrm{ThCl}_{4}(0.049 \mathrm{~g}, 0.132 \mathrm{mmol})$ into $3 \mathrm{M} \mathrm{HCl}(0.5 \mathrm{~mL})$. 4hydroxypyridine $(0.013 \mathrm{~g}, 0.141 \mathrm{mmol})$ was added and the solution was left to evaporate under a nitrogen atmosphere. After approximately 7 days, colorless prismatic crystals formed. IR $\left(\mathrm{cm}^{-1}\right)$ : 443 (w), 458 (w), 510 (vs), 577 (w, b), 639 (w, b), 724 (w, sh), 745 (m, b), 792 (m, b), 825 (w, sh), 850 (s), 877 (m), 976 (w), 1007 (s), 1028 (w), 1046 (w), 1084 (s), 1194 (vs), 1224 (m), 1247 (m), 1267 (m), 1334 (vs), 1358 (m), 1382 (w, sh), 1394 (w, sh), 1505 (vs), 1512 (vs), 1539 (m), 1554 (m), 1558 (s), 1597 (vs), 1605 (vs), 1616 (m), 1623 (s), 1627 (vs), 1632 (s, sh), 1635 (vs), 
1638 (s), 1640 (s, sh), 3072 (s), 3084 9s), 3100 (s), 3178 (s, b), 3238 (s, b). Raman (cm $\left.{ }^{-1}\right): 151$ (m), 181 (s), 224 (m, sh), 234 (s), 264 (s), 515 (m), 529 (w), 646 (w), 852 (vs), 980 (w, b), 1008 (vs), 1046 (m), 1090 (w), 1188 (w), 1330 (m), 1623 (w, sh) 1635 (m, b), 3099 (m).

$\left[\mathrm{Th}\left(\mathrm{H}_{2} \mathrm{O}\right)_{7} \mathrm{Cl}_{2}\right] \mathrm{Cl}_{2} \cdot 2 \mathrm{H}_{2} \mathrm{O}(\mathrm{HPhthal} \cdot \mathrm{Cl})$ (Th-4). An aqueous solution of $\mathrm{Th}(\mathrm{IV})$ in $\mathrm{HCl}$ was prepared in a $3 \mathrm{~mL}$ glass shell vial by dissolving $\mathrm{ThCl}_{4}(0.049 \mathrm{~g}, 0.132 \mathrm{mmol})$ into $3 \mathrm{M} \mathrm{HCl}(0.5$ $\mathrm{mL})$. Phthalazine $(0.017,0.127 \mathrm{mmol})$ was added and the solution was left to evaporate under a nitrogen atmosphere. After approximately 4 days, colorless needle-like crystals formed. IR ( $\mathrm{cm}^{-}$ $\left.{ }^{1}\right)$ : 438 (m), 469 (vs), 472 (vs, sh), 513 (s, sh), 519 (s), 637 (s), 641 (s, sh), 645 (m), 668 (m), 760 (m), $776(\mathrm{~m}), 794(\mathrm{~m}), 812(\mathrm{~m}), 821(\mathrm{~m}), 854(\mathrm{~m}), 890(\mathrm{w}), 952(\mathrm{~m}), 960(\mathrm{~m}), 1021(\mathrm{w}), 1140$ (w), $1172(\mathrm{w}), 1226(\mathrm{~m}), 1240(\mathrm{w}), 1625(\mathrm{~m}), 1287(\mathrm{~m}), 1327(\mathrm{w}), 1342(\mathrm{w}), 1387(\mathrm{~s}), 1424(\mathrm{~m})$, 1451 (m), 1466 (w), 1489 (m), 1537 (w, b), 1550 (w), 1584 (s, sh), 1593 9s, sh), 1607 (s, b), 1624 (s, sh), 2948 (s, b), 3020 (s, b), 3046 (s, b) 3093 (s, b), 3153 (s, b), 3218 (s, b), 3299 (s, b). Raman (cm $\left.{ }^{-1}\right)$ : $194(\mathrm{w}), 452(\mathrm{w}), 515(\mathrm{~s}), 523(\mathrm{w}, \mathrm{sh}), 796(\mathrm{~s}), 1020(\mathrm{~s}), 1137$ (w), $1226(\mathrm{~m})$, 1379 (m, sh), 1387 (s), 1428 (m), 1454 (m), 1490 (m0, 1620 (w), 3049 (m, sh), 3060 (s), 3075 (m, sh), 3243 (w, b).

$\left[\mathrm{Th}\left(\mathrm{H}_{2} \mathrm{O}\right)_{4} \mathrm{Cl}_{4}\right] \cdot 2(3-\mathrm{MePy} \cdot \mathrm{Cl})(\boldsymbol{T h}-5)$. An aqueous solution of $\mathrm{Th}(\mathrm{IV})$ in $\mathrm{HCl}$ was prepared in a 3 $\mathrm{mL}$ glass shell vial by dissolving $\mathrm{ThCl}_{4}(0.049 \mathrm{~g}, 0.132 \mathrm{mmol})$ into $3 \mathrm{M} \mathrm{HCl}(0.5 \mathrm{~mL})$. 3methylpyridine $(12.8 \mu \mathrm{L}, 0.132 \mathrm{mmol})$ was added and the solution was left to evaporate under a nitrogen atmosphere. After approximately 8 days, colorless crystals formed. IR $\left(\mathrm{cm}^{-1}\right): 419(\mathrm{~m})$, 433 (m), 459 (vs), 630 (s), 674 (vs), 686 (s), 747 (m, sh), 776 (s), 805 (m), 874 (w), 903 (w), 918 (w), 953 (w), $981(\mathrm{w}), 991(\mathrm{w}), 1031$ (m), $1046(\mathrm{~m}), 1116$ (s), 1180 (m), 1254 (s), 1386 (m), 1468 (m), 1549 (s), 1612 (s, b), 1620 (s, sh), 1629 (m, sh), 2880 (m), 2934 (m), 3049 (s), 3070 (s), 3086 (s), 3127 (s), 3173 (s), 3219 (s), 3241 (s). Raman (cm $\left.{ }^{-1}\right): 234$ (m), 259 (m), 536 (s), $560(\mathrm{w}, \mathrm{b}), 629$ (w), 805 (vs), 1020 (w, sh), 1031 (vs), 1046 (vs), $1115(\mathrm{w}), 1179(\mathrm{w}), 1187(\mathrm{w})$, 1235 (m), 1253 (w, sh), 1261 (w), 1387 (w, b), 1607 (w), 1631 (w), 2867 (s, b), 2931 (vs), 3045 (m), 3067 (m, b), 3105 (m), 3220 (w, b), 3445(w, b).

\section{$\underline{\mathrm{U} \text { compounds }}$}

$(3-\mathrm{ClPyH})_{2} \mathrm{UCl}_{6}(\boldsymbol{U}-\mathbf{6})$. An aqueous solution of $\mathrm{U}(\mathrm{IV})$ in $\mathrm{HCl}$ was prepared in a $3 \mathrm{~mL}$ glass shell vial by dissolving $\mathrm{UCl}_{4}(0.050 \mathrm{~g}, 0.132 \mathrm{mmol})$ into $3 \mathrm{M} \mathrm{HCl}(0.5 \mathrm{~mL})$. 3-chloropyridine (12.6 $\mu \mathrm{L}, 0.132 \mathrm{mmol}$ ) was added and the solution was left to completely evaporate under a nitrogen atmosphere. After approximately 7 days, green prismatic crystals formed. Elemental Analysis: Found: C, 17.69; H, 1.53; N, 4.08. Calc. for $\mathrm{C}_{10} \mathrm{H}_{10} \mathrm{~N}_{2} \mathrm{Cl}_{8} \mathrm{U}$ : C, 17.67; H, 1.48; N, 4.12\%. Approximate yield based on uranium: $0.088 \mathrm{~g}, 65.47 \%$. IR $\left(\mathrm{cm}^{-1}\right): 419$ (m), 430 (m), 467 (vs), 620 (m), 668 (vs), 730 (vs), 795 (vs), $878(\mathrm{~m}), 917(\mathrm{w}), 938(\mathrm{w}), 988(\mathrm{w}), 1011(\mathrm{w}), 1027(\mathrm{~m})$, 1037 (m), 1069 (w), 1105 (s), 1123 (s), 1182 (w), 1198 (w), 1249 (s), 1271 (w), 1307 (m), 1326 (m), 1350 (w, b), 1407 (w), 1453 (s), 1477 (w), 1528 (s), 1594 (m), 1619 (m), 2850 (m), 2889 (m), 2913 (m), 3034 (s), 3050 (s), 3081 (s), 3095 (s), 3108 (s), 3143 (s), 3203 (s). Raman (cm $\left.{ }^{-1}\right)$ : $116(\mathrm{~m}), 125(\mathrm{~m}), 178(\mathrm{w}), 204(\mathrm{w}), 264(\mathrm{w}), 295(\mathrm{w}, \mathrm{sh}), 301(\mathrm{~s}), 314(\mathrm{w}), 356(\mathrm{w}), 395(\mathrm{w})$, 404 (w), 431 (m), 575 (w), 623 (s), 731 (vs), 1013 (w, sh), 1028 (vs), 1040 (vs), 1056 (w), 1064 (w), $1106(\mathrm{w}), 1112(\mathrm{w}), 1122$ (m), 1173 (w), $1183(\mathrm{~m}), 1236(\mathrm{w}), 1253(\mathrm{~m}), 1313(\mathrm{w}), 1460$ (w), 1598 (w), 1607 (w, sh), 1620 (s), 2911 (w), 3033 (m), 3050 (m, sh), 3063 (m, sh), 3080 (s, sh), 3092 (s), 3205 (w, b), 3238 (w, b), 3333 (w), $3350(w)$. 
$\left[\mathrm{U}\left(\mathrm{H}_{2} \mathrm{O}\right)_{5} \mathrm{Cl}_{4}\right] \cdot\left(\mathrm{H}_{2}\right.$ bipy $\left.\cdot 2 \mathrm{Cl}\right) \cdot \mathrm{H}_{2} \mathrm{O}(\boldsymbol{U}-2)$ and $\left(\mathrm{H}_{2}\right.$ bipy $) \mathrm{UCl}_{6}(\boldsymbol{U}-7)$. An aqueous solution of $\mathrm{U}(\mathrm{IV})$ in $\mathrm{HCl}$ was prepared in a $3 \mathrm{~mL}$ glass shell vial by dissolving $\mathrm{UCl}_{4}(0.050 \mathrm{~g}, 0.132 \mathrm{mmol})$ into $3 \mathrm{M}$ $\mathrm{HCl}(0.5 \mathrm{~mL}) .4,4$ '-bipyridine $(0.0206 \mathrm{~g}, 0.132 \mathrm{mmol})$ was added and the solution was left to evaporate under a nitrogen atmosphere. After approximately 6 days, green triangular crystals and in some cases, green prisms formed. The reaction was repeated several times, yielding $\mathbf{U}-\mathbf{2}$ and U-7 in varying yields; $\mathbf{U}-2$ is the dominant phase. Whereas $\mathbf{U}-7$ is quite stable, the U-aquo-Cl phase is quite unstable and readily degrades once exposed to air. U-2. IR ( $\left.\mathrm{cm}^{-1}\right): 433(\mathrm{w}), 710$ (w), $794(\mathrm{~s}), 841(\mathrm{~m}), 949(\mathrm{w}), 1007(\mathrm{w}), 1039(\mathrm{w}), 1055(\mathrm{w}), 1098(\mathrm{w}), 1120(\mathrm{w}), 1193(\mathrm{~m})$, 1225 (m), 1431 (m, sh), 1458 (s), 1481 (s), 1584 (vs), 1592 (s), 1614 (s, sh), 1621 (vs), 1645 (m), 2854 (m), 2925 (m), 3016 (vs), 3062 (vs), 3090 (vs), 3176 (s), 3227 (s), 3307 (s, b). Raman (cm $\left.{ }^{1}\right): 108(\mathrm{w}), 133(\mathrm{w}, \mathrm{sh}), 150(\mathrm{w}), 161(\mathrm{w}), 185(\mathrm{w}), 198(\mathrm{w}), 217(\mathrm{w}), 258(\mathrm{w}), 339(\mathrm{w}), 561(\mathrm{w})$, $711(\mathrm{w}), 761$ (w), 844 (w), 943 (w), 1013 (s), 1024 (s), 1074 (m), 1193 (w, b), 1224 (w), 1247 (w, b), 1376 (m, sh), 1288 (vs), 1400 (w), 1501 (w, sh), 1524 (s), 1561 (w), 1621 (w, b, sh), 1643 (vs), 1654 (w, sh), 2570 (w), 2808 (w), 2923 (w), 3049 (w), 3065 (w), $3083(\mathrm{w}), 3091(\mathrm{w}), 3114$ (w), $3281(\mathrm{w}), 3326(\mathrm{w}), 3717$ (b), 3885 (b). U-7. IR ( $\left.\mathrm{cm}^{-1}\right)$ : $436(\mathrm{w}), 478(\mathrm{w}), 559(\mathrm{w}), 613(\mathrm{w})$, 637 (w), 656 (m), 669 (w), 709 (s), 741 (m, sh), 769 (vs), 796 (m, sh), 842 (w), $914(\mathrm{w}), 953$ (w, b), $996(\mathrm{~m}), 1007$ (w), $1023(\mathrm{w}), 1041(\mathrm{w}), 1058(\mathrm{~m}), 1066(\mathrm{w}), 1095$ (w, sh), 1105 (m), 1127 (m), 1202 (s), 1226 (s), 1252 (w), 1289 (m), 1315 (w), 1358 (s), 1372 (w), 1403 (w), 1474 (s), 1489 (s), 1576 (w, sh), 1581 (m, sh), 1594 (s), 1617 (w, sh), 1624 (m, sh), 1628 (s), 1638 (m), $1654(\mathrm{w}), 3045(\mathrm{w}), 3085(\mathrm{w}), 3104(\mathrm{w}), 3131(\mathrm{w}), 3172(\mathrm{~m}), 3215(\mathrm{~s})$. Raman $\left(\mathrm{cm}^{-1}\right)$ : $120(\mathrm{~m}$, sh), 130 (m), 243 (w), 300 (m), $334(\mathrm{~m}), 560$ (w), $636(\mathrm{~m}), 719(\mathrm{w}), 761(\mathrm{w}), 817(\mathrm{w}), 1018$ (vs), 1075 (m), 1228 (m), 1265 (m, sh), 1273 (m, sh), 1285 (vs), 1314 (w), 1344 (w), 1515 (m, sh), 1526 (s), 1602 (w), 1621 (m, sh), 1644 (vs), 1657 (s, sh), 1779 (w), 2885 (b), 3083 (m), 3112 m), $3171(\mathrm{~m}), 3196(\mathrm{w}), 32179 \mathrm{~m} 0,3287(\mathrm{w})$.

$\left[\mathrm{U}\left(\mathrm{H}_{2} \mathrm{O}\right)_{7} \mathrm{Cl}_{2}\right] \mathrm{Cl}_{2} \cdot 2 \mathrm{H}_{2} \mathrm{O}(\boldsymbol{U}-\boldsymbol{8}),\left[\mathrm{U}\left(\mathrm{H}_{2} \mathrm{O}\right)_{4} \mathrm{Cl}_{4}\right] \cdot 2(4-\mathrm{OHPyH} \cdot \mathrm{Cl})(\boldsymbol{U}-3)$, and $(4-\mathrm{OHPyH})_{2} \mathrm{UCl}_{6}(\boldsymbol{U}-$ 9). An aqueous solution of $\mathrm{U}(\mathrm{IV})$ in $\mathrm{HCl}$ was prepared in a $3 \mathrm{~mL}$ glass shell vial by dissolving $\mathrm{UCl}_{4}(0.050 \mathrm{~g}, 0.132 \mathrm{mmol})$ into $3 \mathrm{M} \mathrm{HCl}(0.5 \mathrm{~mL})$. 4-hydroxypyridine $(0.0125 \mathrm{~g}, 0.132 \mathrm{mmol})$ was added and the solution was left to evaporate under a nitrogen atmosphere. After approximately 4 days, green prismatic crystals formed along with darker green blocks. It should be noted that this reaction yields many products. (4-OHPyH) $)_{2} \mathrm{UCl}_{6}$ (U-9) crystals are lighter green prismatic crystals that are stable in air and are generally the largest crystals that precipitate. $\left[\mathrm{U}\left(\mathrm{H}_{2} \mathrm{O}\right)_{7} \mathrm{Cl}_{2}\right] \mathrm{Cl}_{2} \cdot 2 \mathrm{H}_{2} \mathrm{O}(\mathbf{U}-8)$ and $\left[\mathrm{U}\left(\mathrm{H}_{2} \mathrm{O}\right)_{4} \mathrm{Cl}_{4}\right] \cdot 2(4-\mathrm{OHPyH} \cdot \mathrm{Cl})(\mathbf{U}-3)$ look similar visually; they are darker green small blocks. Each phase has been observed given the provided experimental synthesis and the details of how to isolate one phase over the other is the focus of future work. Both U-aquo-chloro phases are quite unstable and readily degrade once taken out of a $\mathrm{N}_{2}$ environment. Vibrational spectroscopy could not be collected for $\mathbf{U - 8}$ due to the extreme air sensitivity of these crystals. U-3. IR ( $\mathrm{cm}^{-1}$ ): 450 (vs), 510 (vs), 528 (m), 583 (vs), 640 (w), 718 (m), 753 (vs), 815 (s), 837 (m), 850 (m), 870 (s), 922 (w), 970 (w), 1003 (vs), 1041 (m), 1079 (s), 1181 (vs), 1124 (w), 1259 (w, sh), 1290 (w, sh), 1327 (vs), 1383 (m), 1496 (vs), 1505 (vs), 1585 (s), 1605 (m, sh), 1622 (m, sh), 1634 (s), 1652 (w), 2665 (m), 2950 (m), 3099 (s), 3158 (s), 3283 (s), 3450 (b). Raman (cm $\left.{ }^{-1}\right): 112$ (m, sh), 135 (m), $194(\mathrm{~m}), 210$ (m), 220 (m), 242 (m), 260 (m), 277 (m, sh), 282 (m), 503 (w), 535 (w), 541 (w), 730 (vs), 818 (w), 842 (vs), 1016 (w), 1036 (vs), 1108 (m), 1134 (s), 1226 (w, sh), 1238 (m, sh), 1236 (m), 1264 (w), 1290 (m), 1397 (m), 1440 (m, b), 1546 (w), 1615 (w), 1623 (m), 2756 (w, b), 2870 (m, sh), 2993 (m), 2929 (vs), 2967 (m, sh), 2995 (m), 3029 (m), 3041 (m), 3068 (m), 3074 (m, sh), 3739 (w, b). U-9. IR (cm 
1): 451 (s), $511(\mathrm{vs}), 528(\mathrm{w}), 538(\mathrm{~s}), 640(\mathrm{w}), 719(\mathrm{~m}), 753(\mathrm{~s}), 815(\mathrm{w}), 838(\mathrm{w}), 850(\mathrm{~m}), 870$ (s), 922 (w), 964 (w), 971 (w), 1004 (s), 1040 (s), 1079 (s), 1181 (s), 1194 (w, sh), 1225 (w), 1247 (w), 1264 (w), 1290 (w, sh), 1325 (vs), 1373 (w), $1384(\mathrm{w}), 1496(\mathrm{vs}), 1536$ 9w), 1552 9w), 1576 (w, sh), 1585 (s), 1595 (m), 1605 (m), 1616 (m), 1623 (s), 1627 (m), 1635 (m), 1637 (m), 2663 (w), 2879 (w), $2946(\mathrm{~m}), 3070$ (m), 3086 (m), 3100 (s), 3157 (s), 3282 (s). Raman $\left(\mathrm{cm}^{-1}\right)$ : 112 (vs, sh), 126 (vs), 233 (w), 250 (w), 303 (vs), 413 (w), 431 (w), 519 (w), 539 (m), 646 (m), 720 (w), 794 (w) 818 (w, sh), 827 (w, sh), 848 (vs), 879 (w), 983 (w), 997 (w), 1005 (vs), 1044 (s), 1088 (w), 1180 (w), 1191 (s), 1259 (m), 1327 (m), 1340 (w), $1384(\mathrm{~m}), 1545$ (m), 1604 (w), 1634 (s, sh), 1638 (s), 2850 (b), 3079 (s), 3089 (vs), 3105 (s), 3170 (m, b), 3240 (m, b).

(HPhthal) ${ }_{2} \mathrm{UCl}_{6}(\boldsymbol{U}-10)$. An aqueous solution of $\mathrm{U}(\mathrm{IV})$ in $\mathrm{HCl}$ was prepared in a $3 \mathrm{~mL}$ glass shell vial by dissolving $\mathrm{UCl}_{4}(0.050 \mathrm{~g}, 0.132 \mathrm{mmol})$ into $3 \mathrm{M} \mathrm{HCl}(0.5 \mathrm{~mL})$. Phthalazine $(0.0172 \mathrm{~g}$, $0.132 \mathrm{mmol}$ ) was added and the solution was left to evaporate under a nitrogen atmosphere. After approximately 8 days, green rod crystals formed. Elemental Analysis: Found: C, 27.38; H, 1.88; N, 7.92. Calc. for $\mathrm{C}_{16} \mathrm{H}_{14} \mathrm{~N}_{4} \mathrm{Cl}_{6} \mathrm{U}: \mathrm{C}, 26.95 ; \mathrm{H}, 1.98 ; \mathrm{N}, 7.86 \%$. Approximate yield based on uranium: $0.076 \mathrm{~g}, 81.6 \%$. IR ( $\left.\mathrm{cm}^{-1}\right)$ : 429 (w), 475 (vs), 511 (w), 522 (vs), 639 (s), 643 (s, sh), 767 (s, sh), $774(\mathrm{~s}), 792(\mathrm{~m}), 816(\mathrm{~s}), 836$ (w, sh), $870(\mathrm{~s}), 895(\mathrm{~m}), 915(\mathrm{w}), 954(\mathrm{~s}), 963$ (w), $987(\mathrm{~m}), 1002(\mathrm{w}), 1020(\mathrm{w}), 1138(\mathrm{w}), 1165(\mathrm{w}), 1214(\mathrm{~m}), 1235(\mathrm{~m}), 1248(\mathrm{~m}), 1261(\mathrm{~m})$, 1281 (m), 1318 (w, sh), 1333 (m), 1348 (w), 1375 (m, sh), 1385 (m), 1406 (s), 1417 (m), 1449 (m), 1602 (m), $1616(\mathrm{~m}), 3013$ (s), 3039 (s), 3075 (s), 3115 (s), 3127 (s), 3152 (s). Raman (cm $\left.{ }^{-1}\right)$ : 124 (s), 132 (s), $195(\mathrm{w}), 208(\mathrm{w}), 300(\mathrm{~m}), 364(\mathrm{w}), 391(\mathrm{w}), 451(\mathrm{w}), 479(\mathrm{w}), 517$ (m, sh), 521 (vs), $638(\mathrm{w}), 645(\mathrm{w}), 787(\mathrm{w}, \mathrm{sh}), 794(\mathrm{~s}), 810(\mathrm{w}), 984(\mathrm{w}), 1020(\mathrm{~s}), 1137(\mathrm{w}), 1220(\mathrm{~m})$, 1384 (m), 1441 (m, sh), 1447 (s), 1470 (m), 1475 (m, sh), 1487 (s), 1517 (m), 1829 (m), 2855 (m), $3076(\mathrm{~m}), 3167(\mathrm{~m}), 3461(\mathrm{~m})$.

(3- $\mathrm{MePyH})_{2} \mathrm{UCl}_{6}(\boldsymbol{U}-11)$. An aqueous solution of $\mathrm{U}(\mathrm{IV})$ in $\mathrm{HCl}$ was prepared in a $3 \mathrm{~mL}$ glass shell vial by dissolving $\mathrm{UCl}_{4}(0.050 \mathrm{~g}, 0.132 \mathrm{mmol})$ into $3 \mathrm{M} \mathrm{HCl}(0.5 \mathrm{~mL})$. 3-methylpyridine $(12.84 \mu \mathrm{L}, 0.132 \mathrm{mmol})$ was added and the solution was left to evaporate under a nitrogen atmosphere. After approximately 8 days, large emerald green prisms formed. Elemental Analysis: Found: C, 21.95; $\mathrm{H}, 2.47$; N, 4.28. Calc. for $\mathrm{C}_{12} \mathrm{H}_{16} \mathrm{~N}_{2} \mathrm{Cl}_{6} \mathrm{U}$ : C, 22.56; $\mathrm{H}, 2.52 ; \mathrm{N}$, 4.38\%. Yield based on uranium: $0.062 \mathrm{~g}, 74.7 \%$. IR ( $\left.\mathrm{cm}^{-1}\right)$ : $456(\mathrm{vs}), 505(\mathrm{w}), 559(\mathrm{w}), 629(\mathrm{w})$, 676 (vs), 774 (vs), 793 (w, sh), 805 (w), 872 (m), 921 (m), 984 (w), 1012 (m), 1031 (w), 1047 (m), $1075(\mathrm{w}), 1116(\mathrm{~s}), 1138(\mathrm{w}), 1181(\mathrm{w}), 1258(\mathrm{~m}), 1304(\mathrm{w}), 1339(\mathrm{w}), 1345(\mathrm{w}), 1388(\mathrm{w})$, 1466 (m, sh), 1475 (m), 1550 (vs), 1608 (s), 1630 (s), 2889 (w), 2936 (w), 3041 (m), 3081 (s), 3091 (m, sh), 3129 (s), 3174 (s), 3188 (s), 3221 (s), 3243 (s). Raman (cm-1): 121 (s), 238 (w), 302 (vs), 347 (w), 401 (w), 532 (m), 630 (w), 792 (m), $799(\mathrm{~m}), 806(\mathrm{~m}), 842$ (w), $1020(\mathrm{w})$, 1031 (vs), 1046 (vs), 1116 (w), 1181 (m), $1231(\mathrm{~m}), 1260(\mathrm{~m}), 1341(\mathrm{w}), 1388(\mathrm{w}), 1606(\mathrm{~m})$, 1630 (m), 2934 (s), 2968 (w, sh), 3039 (s), 3054 (m), 3083 (s), 3101 (m, sh), 3172 (w), 3224 (w, b), $3251(w, b)$.

\section{Pu compounds}

Preparation of ${ }^{239} \mathrm{Pu}(\mathrm{IV}) / \mathrm{HCl}$ stock solution: An aliquot of a (dark green, almost black) legacy solution of $\mathrm{Pu}$ in nitric acid was taken and the volume was reduced. The acid concentration was adjusted to $8 \mathrm{M}$. This dark green solution was in turn loaded onto a Dowex 1-X8 column - it formed an emerald green band - and was rinsed with 6 column volumes of $8 \mathrm{M} \mathrm{HNO}_{3}$. The $\mathrm{Pu}$ 
was then eluted using $1 \mathrm{M} \mathrm{HCl}$ as a yellow/orange solution. The volume was reduced to near dryness using a vapor capture system, i.e. a round bottom flask and condenser and rehydrated with concentrated $\mathrm{HCl}$; the color become an orange/red. This solution was heated until dryness and in turn rehydrated with concentrated $\mathrm{HCl}$ - this was done 3 times. After the fourth addition of $\mathrm{HCl}$, the solution was cooled and $30 \% \mathrm{H}_{2} \mathrm{O}_{2}$ was added to reduce all $\mathrm{Pu}$ to the +3 oxidation state (the solution was a Robin's egg blue color). After $\sim 24$ hours the solution was gently taken to dryness to drive off the excess $\mathrm{H}_{2} \mathrm{O}_{2}$. The remaining solids were dissolved in $10 \mathrm{M} \mathrm{HCl}$ and the volume adjusted to $6 \mathrm{~mL}$. This 'stock' was orange/crimson red in color and gamma spectroscopy and UV-Vis absorption spectroscopy were used to characterize the solution to be $17.5 \mathrm{mg} / \mathrm{mL}$ of ${ }^{239} \mathrm{Pu}(\mathrm{IV})$. This stock solution was used in the synthesis of Pu-9 and Pu-11. A similar procedure was performed to yield a separate stock solution used in the synthesis of Pu-6, $\mathbf{P u}-7$, and $\mathbf{P u - 1 0}$. The final concentration of this $\mathrm{Pu}(\mathrm{IV}) / \mathrm{HCl}$ stock solution was determined to be $105 \mathrm{mg}{ }^{239} \mathrm{Pu}(\mathrm{IV}) / 6 \mathrm{~mL} 10 \mathrm{M} \mathrm{HCl}$ by gamma spectroscopy. UV-Vis spectroscopy confirmed the oxidation state of the $\mathrm{Pu}$ to be +4 .

General Sample Preparation of ${ }^{239} \mathrm{Pu}$-Cl compounds: In a $10 \mathrm{~mL}$ screw cap vial, $0.05 \mathrm{M} \mathrm{HCl}$ and the appropriate $\mathrm{N}$-containing heterocycle were mixed outside of the radiological glovebox under ambient conditions. Once inside the glovebox, the ${ }^{239} \mathrm{Pu}(\mathrm{IV}) / \mathrm{HCl}$ stock solution was added to the vial so that the final concentration of $\mathrm{HCl}$ was approximately $3 \mathrm{M}$. The solution was gently mixed by hand and placed in a conical vial or plastic box lined with desiccant for slow evaporation (Photo S1). Enclosure of the reaction solutions within these conical vials limited corrosion of the stainless steel glovebox from evaporation of $\mathrm{HCl}$.

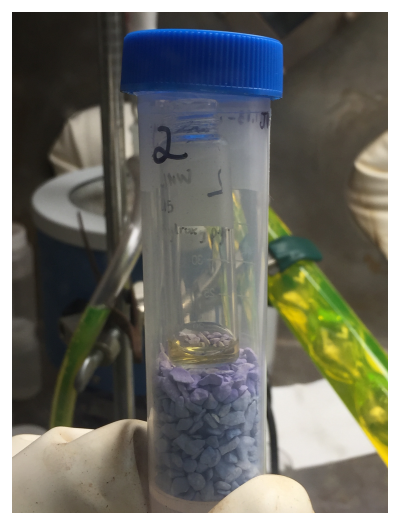

Photo S1. Experimental Pu reaction solution contained within a conical vial lined with desiccant to limit $\mathrm{HCl}$ corrosion of the stainless steel glovebox.

(3-ClPyH) ${ }_{2} \mathrm{PuCl}_{6}(\mathbf{P u}-\mathbf{6}) .0 .05 \mathrm{M} \mathrm{HCl}(349 \mu \mathrm{L})$ and 3-chloropyridine (1.04 $\left.\mu \mathrm{L}, 0.011 \mathrm{mmol}\right)$ were added to a $10 \mathrm{~mL}$ screw cap glass vial. The ${ }^{239} \mathrm{Pu}(\mathrm{IV}) / \mathrm{HCl}$ stock solution $(150 \mu \mathrm{L}, 0.011$ mmol) was then added to the vial to yield a final volume of $500 \mu \mathrm{L}$ and a final $\mathrm{HCl}$ concentration of $3 \mathrm{M}$. The yellow/orange solution was gently mixed by hand and left to slowly evaporate under ambient conditions. After approximately 10 days, light orange crystals formed.

( $\mathrm{H}_{2}$ bipy) $\mathrm{PuCl}_{6}$ (Pu-7). $0.05 \mathrm{M} \mathrm{HCl}(350 \mu \mathrm{L})$ and 4,4'bipyridine (1.6 $\left.\mathrm{mg}, 0.010 \mathrm{mmol}\right)$ were added to a $10 \mathrm{~mL}$ screw cap glass vial. The ${ }^{239} \mathrm{Pu}(\mathrm{IV}) / \mathrm{HCl}$ stock solution $(150 \mu \mathrm{L}, 0.011 \mathrm{mmol})$ was then added to the vial to yield a final volume of $500 \mu \mathrm{L}$ and a final $\mathrm{HCl}$ concentration of 3 M. The yellow/orange solution was gently mixed by hand and left to slowly evaporate under 
ambient conditions. After approximately 7 days, orange crystals formed. Raman $\left(\mathrm{cm}^{-1}\right): 304(\mathrm{~m})$, 336 (w), 564 (w), 642 (w), 759(w), 1011 (s, sh) 1018 (vs), 1078 (w), 1231 (w, b), 1284 (vs), 1295 (s, sh), 1524 (m), 1644 (s).

(4-OHPyH) ${ }_{2} \mathrm{PuCl}_{6}(\mathbf{P u}-9) .0 .05 \mathrm{M} \mathrm{HCl}(700 \mu \mathrm{L})$ and 4-hydroxypyridine (4.1 $\left.\mathrm{mg}, 0.010 \mathrm{mmol}\right)$ were added to a $10 \mathrm{~mL}$ screw cap glass vial. The ${ }^{239} \mathrm{Pu}(\mathrm{IV}) / \mathrm{HCl}$ stock solution $(300 \mu \mathrm{L}, 0.011$ mmol) was then added to the vial to yield a final volume of $1000 \mu \mathrm{L}$ and a final $\mathrm{HCl}$ concentration of $3 \mathrm{M}$. The yellow/orange solution was gently mixed by hand and left to slowly evaporate under ambient conditions. After approximately 7 days, orange crystals formed.

(HPhthal) ${ }_{2} \mathrm{PuCl} 6(\boldsymbol{P u}-10) .0 .05 \mathrm{M} \mathrm{HCl}(350 \mu \mathrm{L})$ and phthalazine $(2.2 \mathrm{mg}, 0.017 \mathrm{mmol})$ were added to a $10 \mathrm{~mL}$ screw cap glass vial. The ${ }^{239} \mathrm{Pu}(\mathrm{IV}) / \mathrm{HCl}$ stock solution $(150 \mu \mathrm{L}, 0.011 \mathrm{mmol})$ was then added to the vial to yield a final volume of $500 \mu \mathrm{L}$ and a final $\mathrm{HCl}$ concentration of 3 M. The yellow/orange solution was gently mixed by hand and left to slowly evaporate under ambient conditions. After approximately 7 days, a large orange crystal formed. Raman $\left(\mathrm{cm}^{-1}\right)$ : 303 (vs), 524 (vs), 784 (w, sh), 794 (m), 1021 (s), 1025 (s, sh), 1032 (m, sh), 1136 (w), 1221 (m), 1227 (m, sh), 1377 (m, sh), 1384 (m), 1409 (m, sh), 1415 (m), 1433 (m), 1447 (s), 1450 (m, sh), $1470(\mathrm{w}), 1485$ (s, b), $1518(\mathrm{~m}), 1613(\mathrm{~m})$.

(3- $\mathrm{MePyH})_{2} \mathrm{PuCl}_{6}(\boldsymbol{P u}-11) .0 .5 \mathrm{M} \mathrm{HCl}(700 \mu \mathrm{L})$ and the ${ }^{239} \mathrm{Pu}(\mathrm{IV}) / \mathrm{HCl}$ stock solution $(300 \mu \mathrm{L}$, $0.011 \mathrm{mmol}$ ) were added to a vial to yield a final volume of $1000 \mu \mathrm{L}$ and a final $\mathrm{HCl}$ concentration of $3 \mathrm{M} .1 / 3$ of this solution was combined with $1 \mathrm{uL}$ of 4-methylpyridine and left to evaporate under ambient conditions. After approximately 7 days, orange crystals formed.

\section{Crystallographic refinement details}

Note: All of the crystallographic details can be found in the experimental refinement section of the crystallographic information files $(C I F$ s). Details are also provided below.

Generally, all non-hydrogen atoms were located within the Fourier difference maps and refined anisotropically. If present, hydrogens bound to hydrogen-bonding donor atoms (i.e. $\mathrm{N}$ and $\mathrm{O}$ ) were found within the Fourier difference map unless stated otherwise. If the X-H distance $(\mathrm{X}=\mathrm{N}, \mathrm{O})$ was not within reasonable limits, the distance was fixed; for water molecules, $\mathrm{O}-\mathrm{H}$ distances were fixed at $0.88(0.02) \AA$ and for protonated nitrogen atoms contained within the heterocycles, N-H distances were fixed at 0.86(0.02) $\AA$. Protonated nitrogen and water $\mathrm{H}$ atom $\mathrm{U}_{\text {eq }}$ values were assigned as 1.5 times their carrier atom. Remaining $\mathrm{H}$ atoms bound to carbons of the $\mathrm{N}$-containing heterocycles were placed in calculated positions and were allowed to ride on their parent atom $\left(1.2\right.$ times $\left.\mathrm{U}_{\mathrm{eq}}\right)$.

Th compounds.

Th-1: This structure was refined as a two-component twin.

Th-2: No further details.

Th-3: The lattice chloride anion is disordered over two positions. Similar displacement amplitudes (esd 0.01) were imposed on disordered sites overlapping by less than the sum of van der Waals radii. Additionally, one of the 4-hydroxypyridinium cations is disordered across a symmetry site. The disordered ring is constrained to be a perfect hexagon. Hydroxyl $\mathrm{H}$ atom 
positions, R-OH, were optimized by rotation about R-O bonds with idealized $\mathrm{O}-\mathrm{H}$ and $\mathrm{R}-\mathrm{H}$ distances.

Th-4: An extinction coefficient was applied.

Th-5: One of the 3-MePyH cations is disordered over two positions. The methyl group of this ring was restrained to behave isotropically. Rigid bond restraints were applied to the entire structure.

U compounds.

U-6: No further details.

U-2: The $H$ atoms of water molecules bound to $U$ could not be located in the difference map and therefore were left out of the structural model. An extinction coefficient was applied. The $\left(\begin{array}{lll}0 & 0 & 6\end{array}\right)$ and $\left(\begin{array}{lll}0 & 0 & 2\end{array}\right)$ reflections were omitted from the final refinement because they were partially obscured by the shadow of the beam stop.

U-7: No further details.

U-8: An extinction coefficient was applied. ( $\left(\begin{array}{lll}2 & 0 & 0\end{array}\right),\left(\begin{array}{lll}0 & 0 & 6\end{array}\right),\left(\begin{array}{lll}0 & 2 & 0\end{array}\right)$, and $\left(\begin{array}{lll}0 & 0 & 2\end{array}\right)$ reflections were omitted from the final refinement because they were partially obscured by the shadow of the beam stop.

U-3: One of the 4-OHPyH cations was disordered across a symmetry site using a negative PART command. The rings of the disordered molecule were constrained to be perfect hexagons. SADI, ISOR, and RIGU restraints were used. EADP constraints were used for $\mathrm{C} 1 / \mathrm{C} 1 \mathrm{~B}$ and $\mathrm{C} 5 / \mathrm{C} 5 \mathrm{~B}$. N$\mathrm{H}$ or $\mathrm{O}-\mathrm{H}$ hydrogens could not be found in the difference map, so they were placed in calculated positions. Due to symmetry, the hydrogens on O5 are in negative PARTs.

U-9: No further details.

U-10: An extinction coefficient was applied. The (-2 $\left.10 \begin{array}{ll}-2 & 0\end{array}\right)$ and ( $\left.\begin{array}{lll}4 & -2 & 1\end{array}\right)$ reflections were omitted due to partial obstruction from the beam stop.

U-11: No further details.

Pu compounds.

Pu-6: The (-2 0 4) reflection was omitted from the final refinement because it was partially obscured by the shadow of the beam stop.

Pu-7: The (2 $\left.\begin{array}{ll}2 & 0\end{array}\right),\left(\begin{array}{lll}0 & 0 & 1\end{array}\right),\left(\begin{array}{lll}1 & 3 & 1\end{array}\right),\left(\begin{array}{lll}-2 & 0 & 2\end{array}\right)$, and (4 $\left.\begin{array}{lll}0 & 0\end{array}\right)$ reflections were omitted from the final refinement because they were partially obscured by the shadow of the beam stop.

Pu-9: The hydroxyl $\mathrm{H}$ atom could not be located in the difference map and therefore was placed in a calculated position. The $\left(\begin{array}{lll}1 & 0 & 0\end{array}\right),\left(\begin{array}{lll}-2 & 2 & 2\end{array}\right)$, and $\left(\begin{array}{lll}1 & 1 & 3\end{array}\right)$ reflections were omitted from the final refinement because they were partially obscured by the shadow of the beam stop.

Pu-10: The ( $\left.\begin{array}{lll}2 & -1 & 1\end{array}\right),\left(\begin{array}{lll}4 & -2 & 1\end{array}\right)$, and ( $\left.\begin{array}{lll}1 & 0 & 1\end{array}\right)$ reflections were omitted from the final refinement because they were partially obscured by the shadow of the beam stop.

Pu-11: The (lllll $\left.\begin{array}{lll}0 & 1 & 1\end{array}\right)$ and $\left(\begin{array}{lll}0 & 2 & 0\end{array}\right)$ reflections were omitted from the final refinement because they were partially obscured by the shadow of the beam stop. 


\section{ORTEP diagrams}

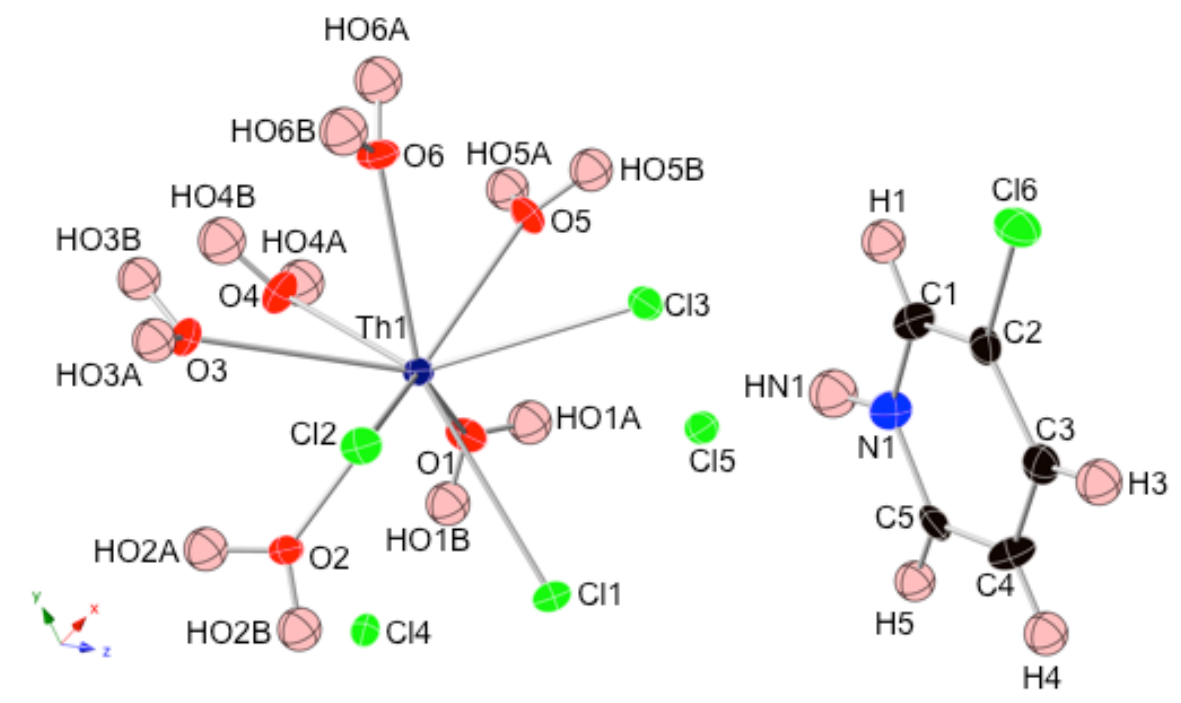

Figure S1. Thermal ellipsoid plot (50\% probability level) of $\left[\mathbf{T h}\left(\mathbf{H}_{2} \mathbf{O}\right)_{6} \mathbf{C l} \mathbf{l}_{3}\right] \mathbf{C l} \cdot(\mathbf{3}-\mathbf{C I P y H} \cdot \mathbf{C l})$ at $100 \mathrm{~K}$.

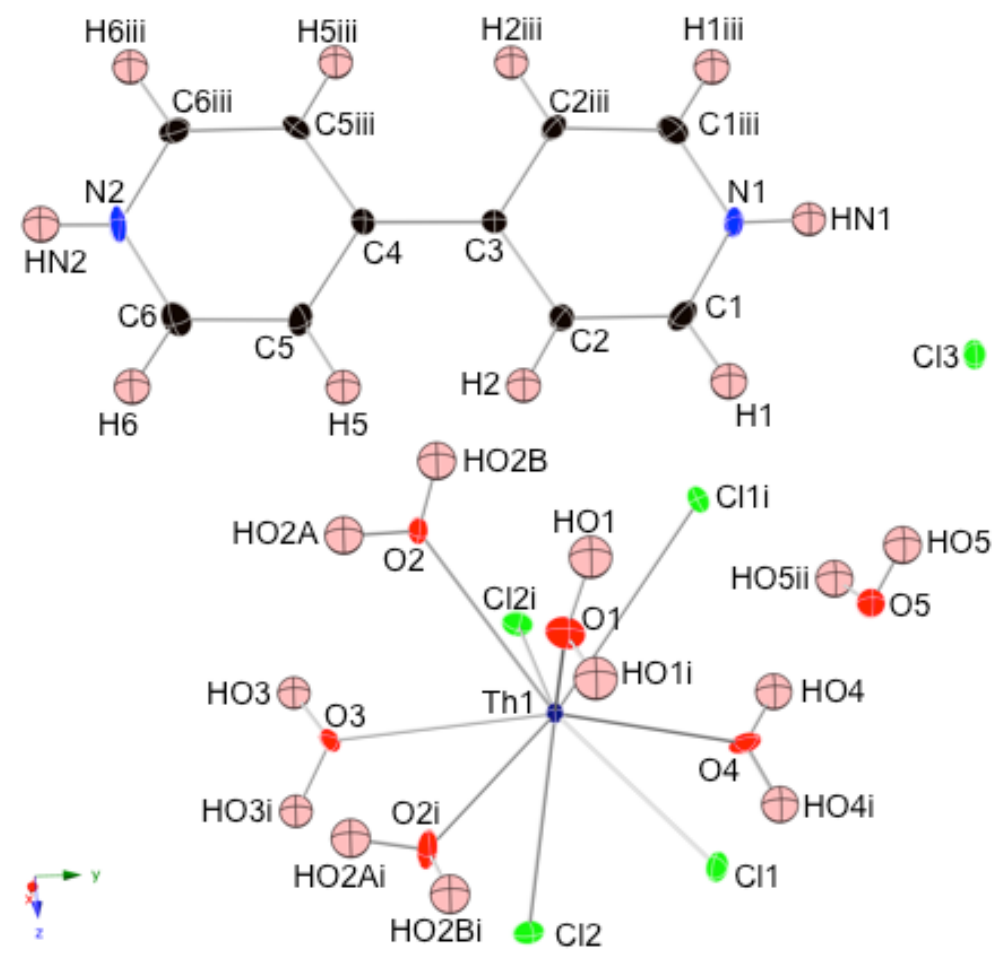

Figure S2. Thermal ellipsoid plot (50\% probability level) of $\left[\mathbf{T h}\left(\mathbf{H}_{2} \mathbf{O}\right)_{5} \mathbf{C l}_{4}\right] \cdot\left(\mathbf{H}_{2} \mathbf{b i p y} \cdot \mathbf{2} \mathbf{C l}\right) \cdot \mathbf{H}_{2} \mathbf{O}$ at $100 \mathrm{~K}$. Symmetry equivalent atoms were generated through their respective symmetry elements $(\mathrm{i}=\mathrm{x}, \mathrm{y},-\mathrm{z}+1, \mathrm{ii}=-\mathrm{x}+1,-\mathrm{y}+1, \mathrm{z}, \mathrm{iii}=\mathrm{x}, \mathrm{y},-\mathrm{z})$. 


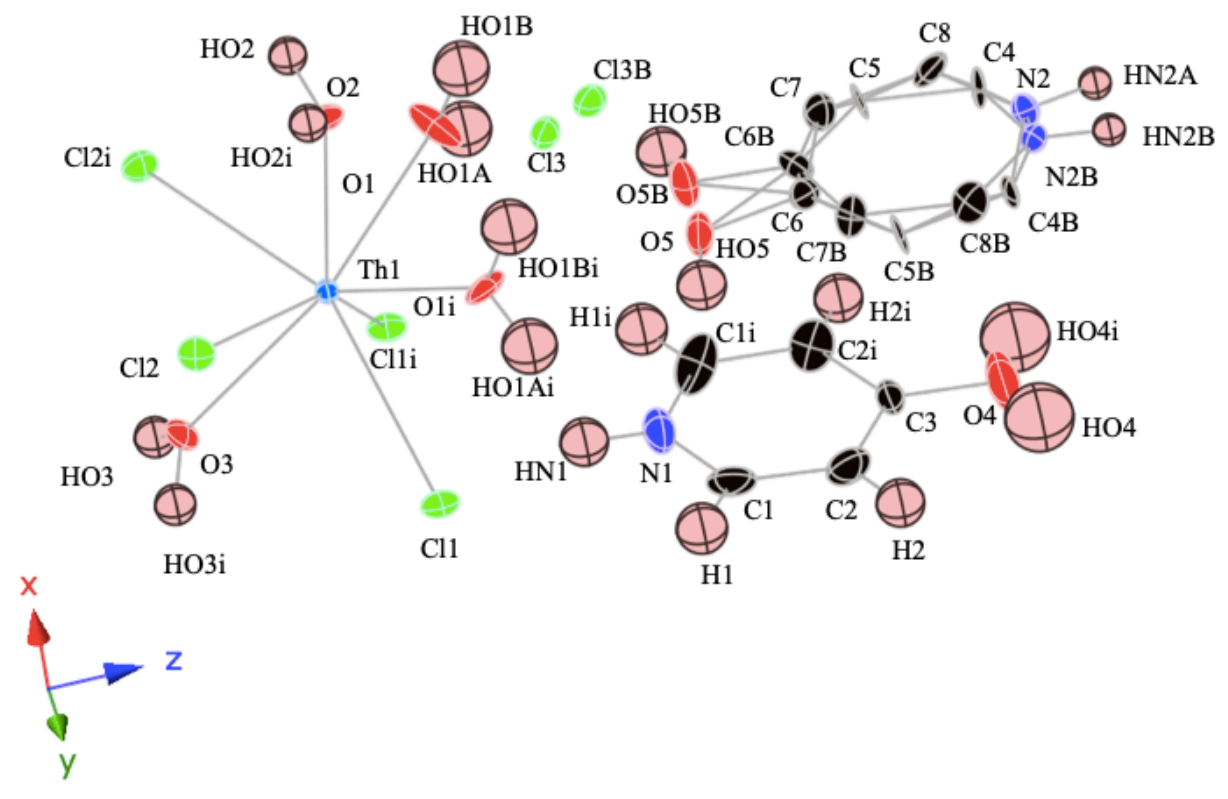

Figure S3. Thermal ellipsoid plot (50\% probability level) of $\left[\mathbf{T h}\left(\mathbf{H}_{2} \mathbf{O}\right)_{4} \mathbf{C l}_{4}\right] \cdot \mathbf{2}(4-\mathbf{O H P y H} \cdot \mathbf{C l})$ at $100 \mathrm{~K}$. Symmetry equivalent atoms were generated through their respective symmetry elements $(\mathrm{i}=\mathrm{x},-\mathrm{y}+1 / 2, \mathrm{z})$

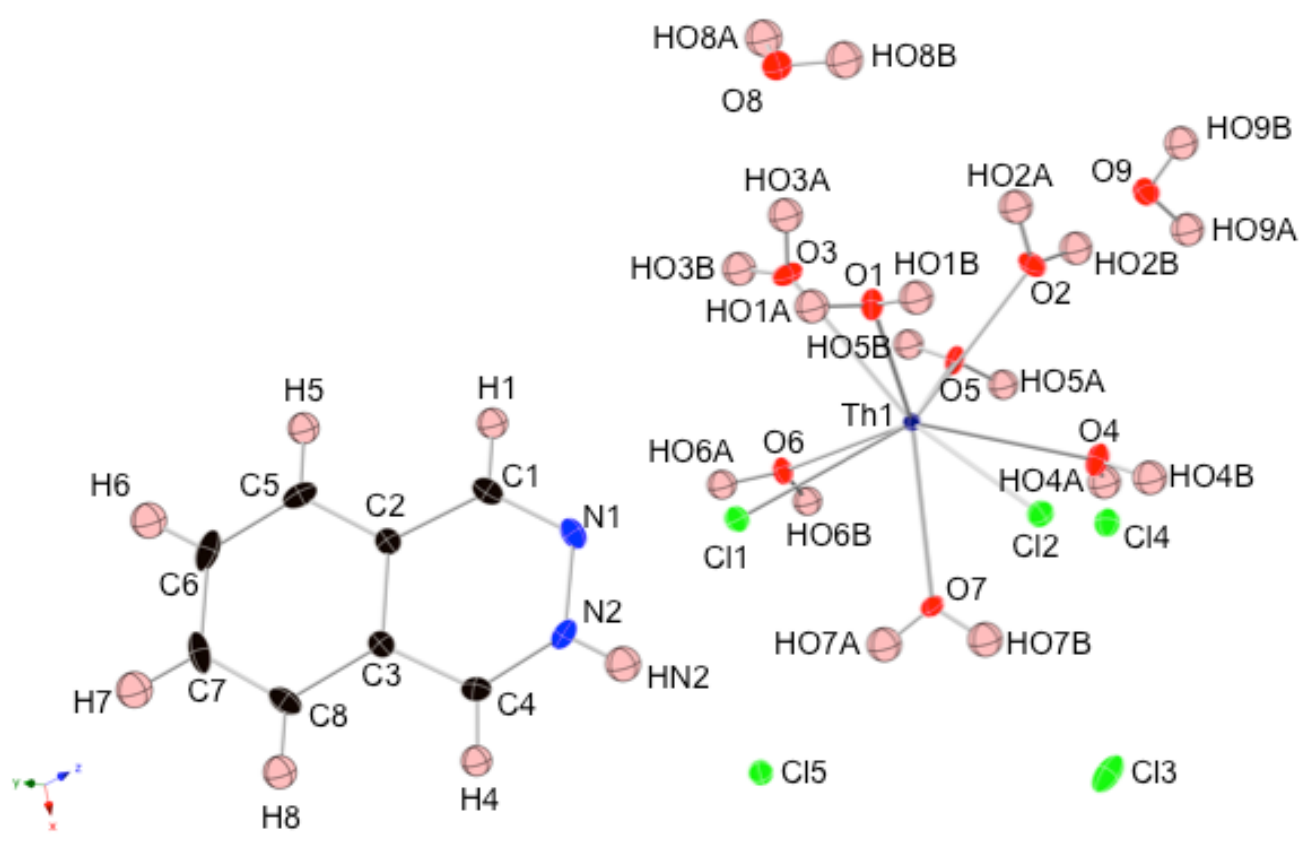

Figure S4. Thermal ellipsoid plot $(50 \%$ probability level $)$ of $\left[\mathbf{T h}\left(\mathrm{H}_{2} \mathbf{O}\right)_{7} \mathrm{Cl}_{2}\right] \mathbf{C l}_{2} \cdot \mathbf{2} \mathrm{H}_{2} \mathbf{O} \cdot(\mathrm{HPhthal} \cdot \mathbf{C l})$ at $100 \mathrm{~K}$. 


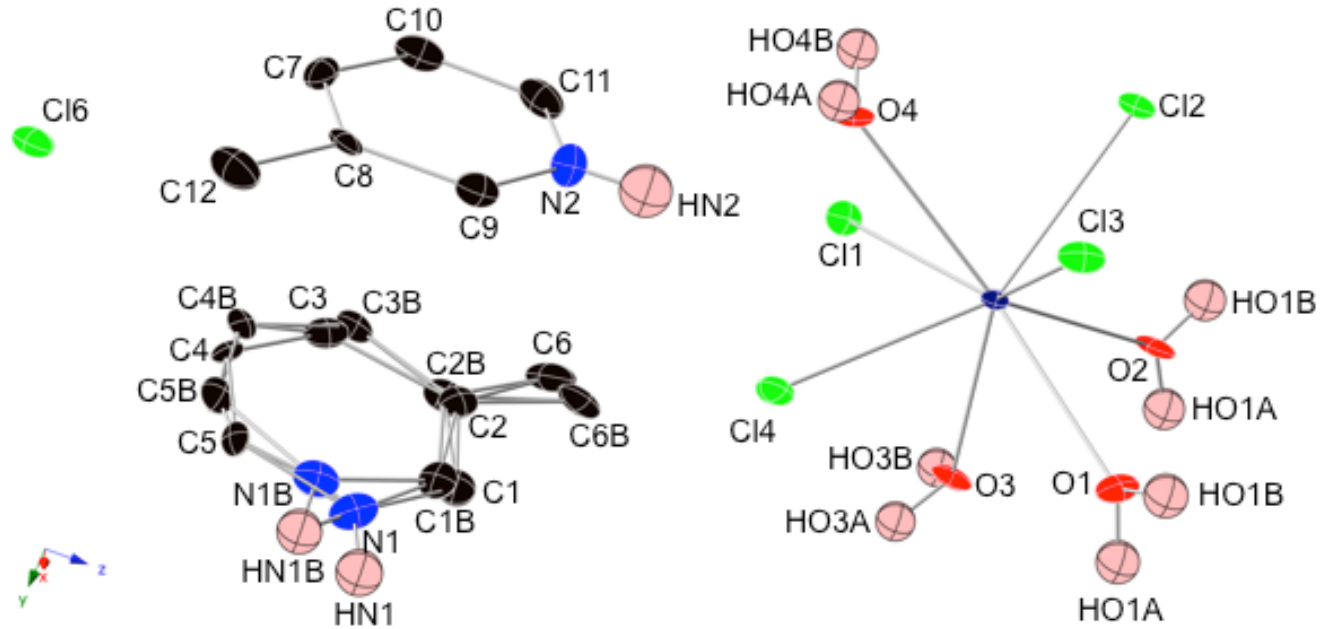

Figure S5. Thermal ellipsoid plot $(50 \%$ probability level $)$ of $\left[\mathbf{T h}\left(\mathrm{H}_{2} \mathbf{O}\right)_{4} \mathbf{C l}_{4}\right] \cdot 2(3-\mathrm{MePy} \cdot \mathbf{C l})$ at $100 \mathrm{~K}$. Hydrogen atoms of the 3-MePyH cations have been omitted for clarity with the exception of those $\mathrm{H}$ atoms bound to nitrogens.
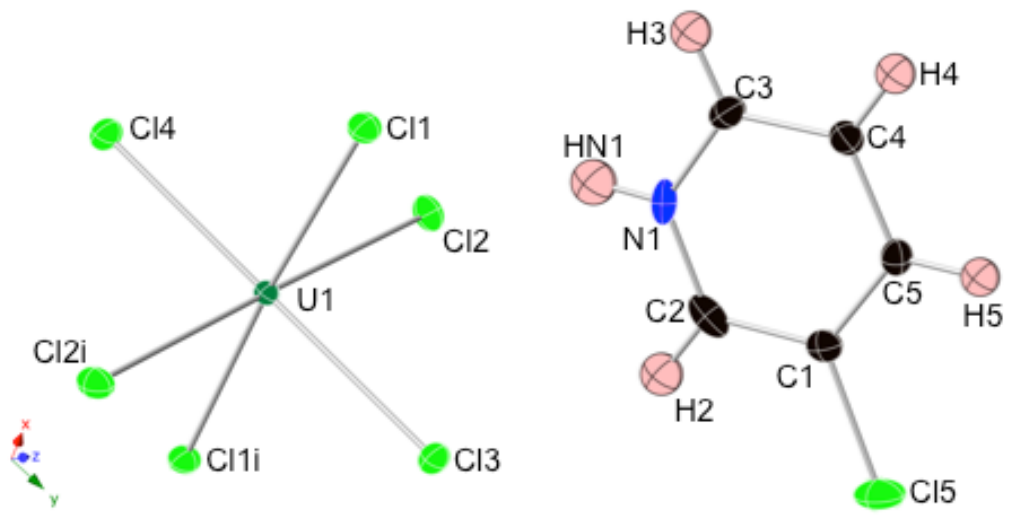

Figure S6. Thermal ellipsoid plot (50\% probability level) of (3-CIPyH) $\mathbf{U}_{\mathbf{2}} \mathbf{U C l}_{\mathbf{6}}$ at $100 \mathrm{~K}$. Symmetry equivalent atoms were generated through their respective symmetry elements $(i=-x+1, y,-z+1 / 2)$. 


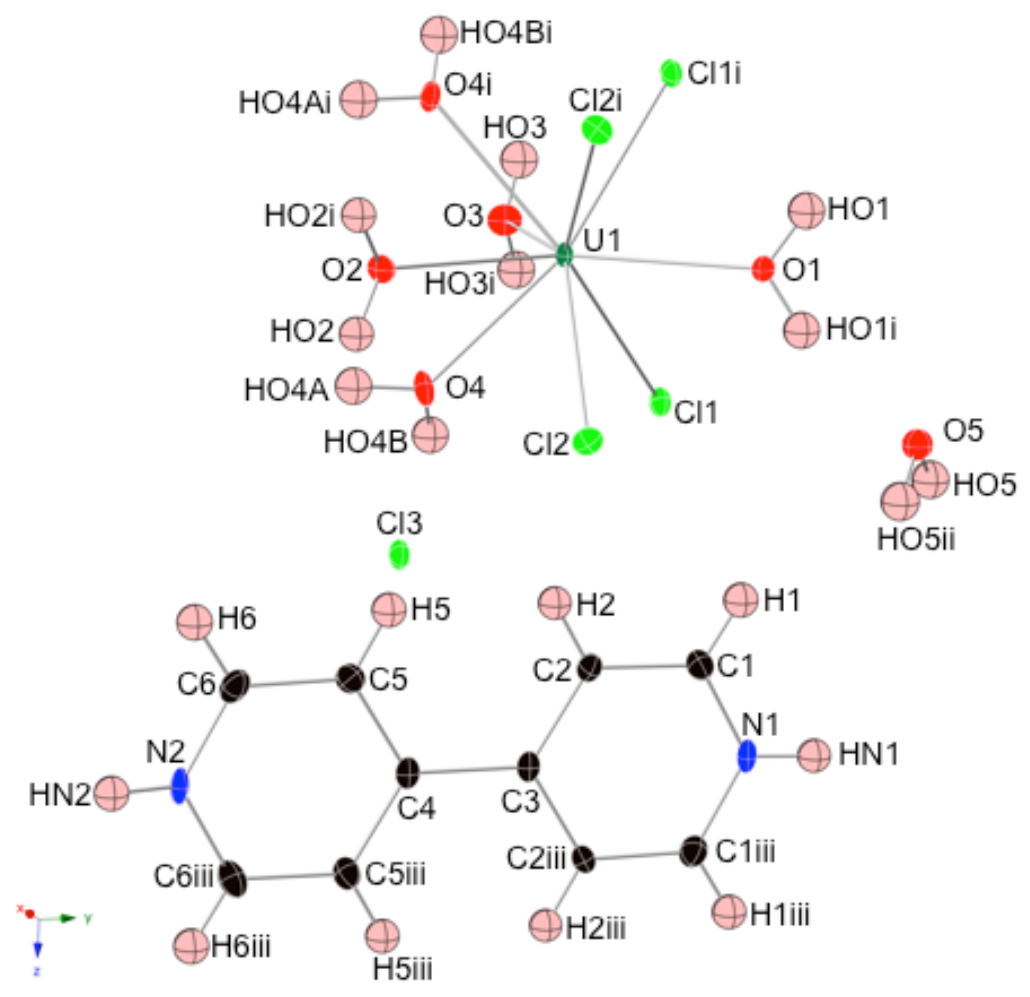

Figure S7. Thermal ellipsoid plot (50\% probability level) of $\left[\mathbf{U}\left(\mathbf{H}_{2} \mathbf{O}\right)_{5} \mathbf{C l}_{4}\right] \cdot\left(\mathbf{H}_{2} \mathbf{b i p y} \cdot \mathbf{2} \mathbf{C l}\right) \cdot \mathbf{H}_{2} \mathbf{O}$ at $293 \mathrm{~K}$. Symmetry equivalent atoms were generated through their respective symmetry elements (i=x, y, $-\mathrm{z}, \mathrm{ii}=-\mathrm{x},-\mathrm{y}+1, \mathrm{z}, \mathrm{iii}=\mathrm{x}, \mathrm{y},-\mathrm{z}+1)$.

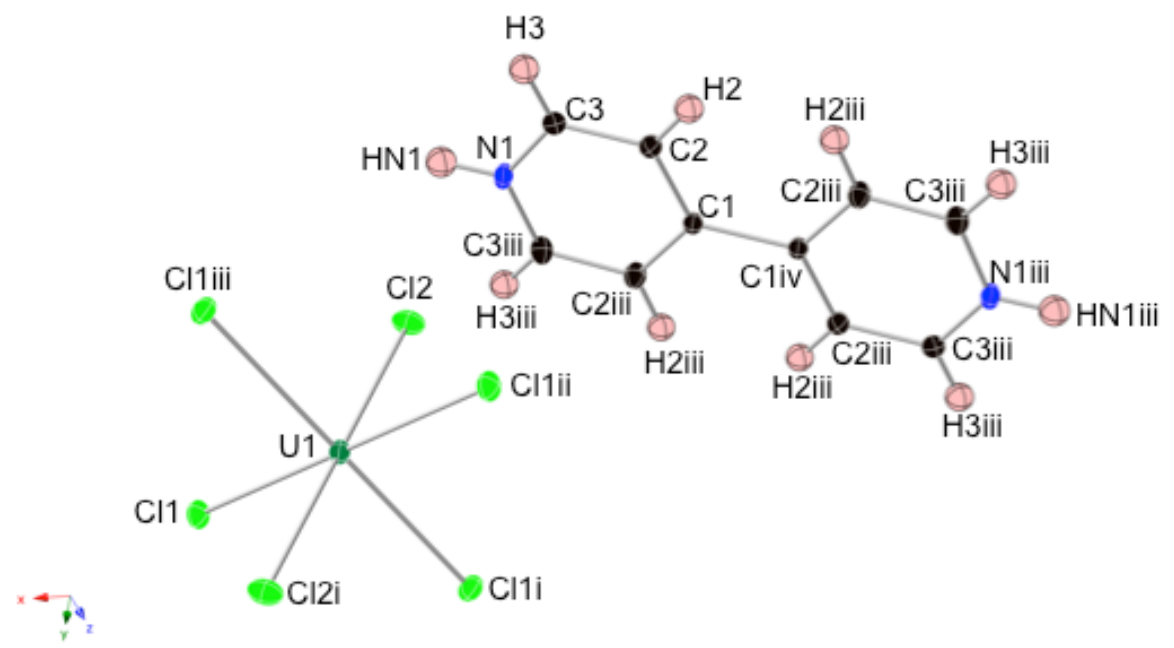

Figure S8. Thermal ellipsoid plot (50\% probability level) of (4-OHPyH) $)_{2} \mathbf{U C l}_{6}$ at $100 \mathrm{~K}$. Symmetry equivalent atoms were generated through their respective symmetry elements $(\mathrm{i}=$ $\mathrm{x}+1,-\mathrm{y}+1,-\mathrm{z}+2, \mathrm{ii}=-\mathrm{x}+1, \mathrm{y},-\mathrm{z}+2, \mathrm{iii}=\mathrm{x},-\mathrm{y}+1, \mathrm{z}, \mathrm{iv}=-\mathrm{x},-\mathrm{y}+1,-\mathrm{z}+1)$. 


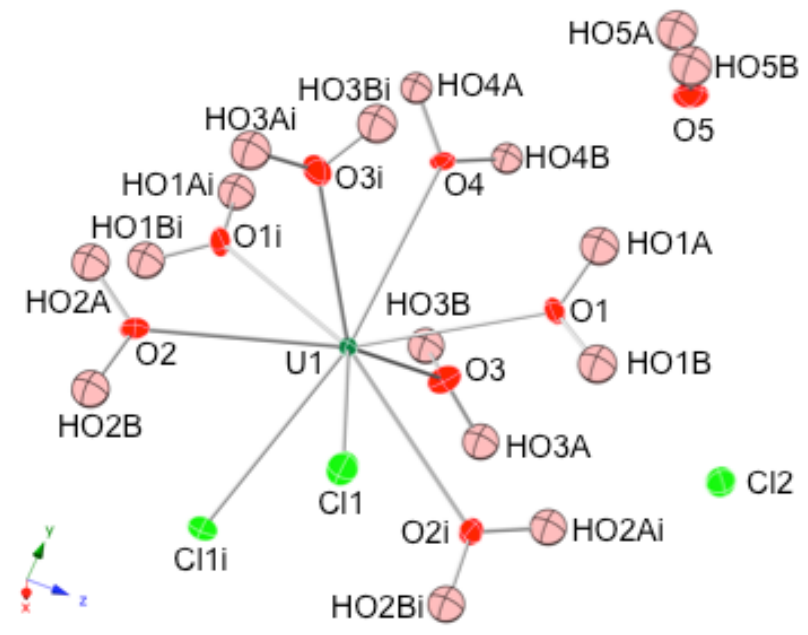

Figure S9. Thermal ellipsoid plot (50\% probability level) of $\left[\mathbf{U}\left(\mathbf{H}_{2} \mathbf{O}\right)_{7} \mathbf{C l}_{2}\right] \mathbf{C l}_{2} \cdot \mathbf{2} \mathbf{H}_{2} \mathbf{O}$ at $100 \mathrm{~K}$. Symmetry equivalent atoms were generated through their respective symmetry elements $(\mathrm{i}=-\mathrm{x}+1$, $\mathrm{y},-\mathrm{z}+1 / 2)$.

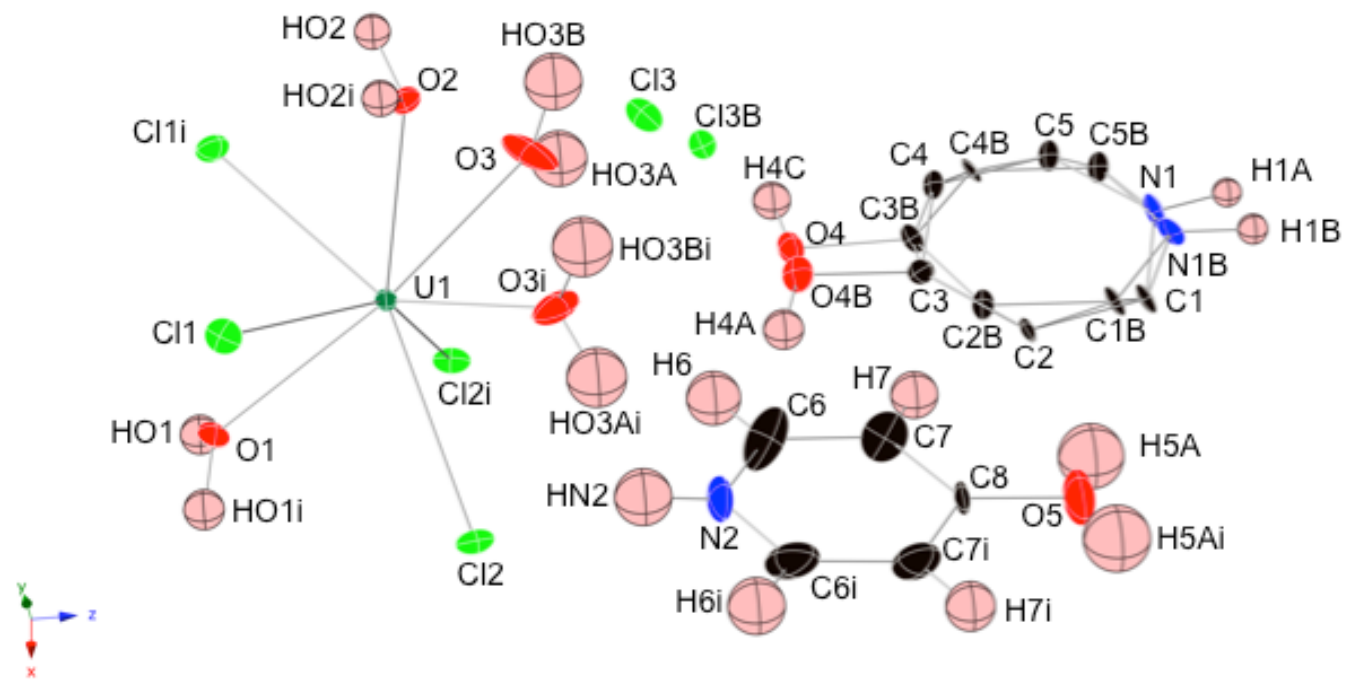

Figure S10. Thermal ellipsoid plot (50\% probability level) of $\left[\mathbf{U}\left(\mathbf{H}_{2} \mathbf{O}\right)_{4} \mathbf{C l}_{4}\right] \cdot 2(4-\mathbf{O H P y H} \cdot \mathbf{C l})$ at $100 \mathrm{~K}$. Symmetry equivalent atoms were generated through their respective symmetry elements $(\mathrm{i}=-\mathrm{x},-\mathrm{y}+1 / 2, \mathrm{z})$. 


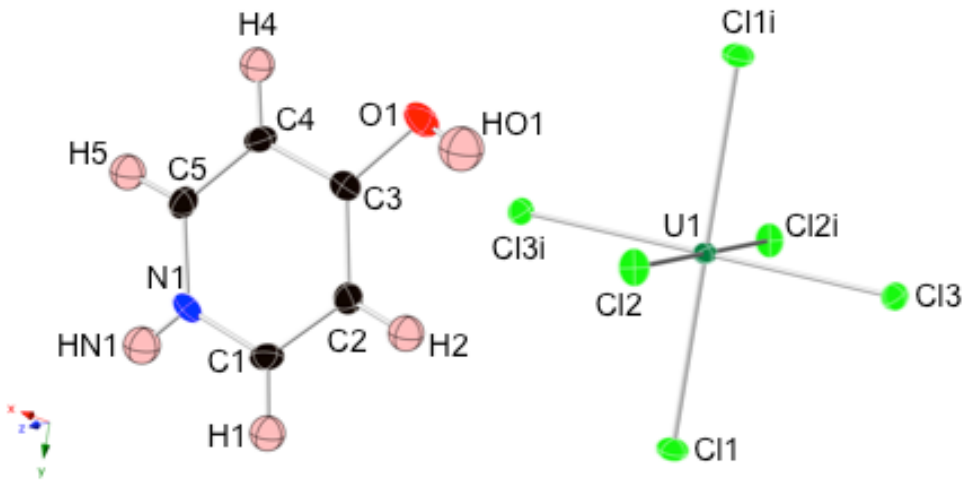

Figure S11. Thermal ellipsoid plot (50\% probability level) of (4-OHPyH) $\mathbf{U C C l}_{\mathbf{6}}$ at $100 \mathrm{~K}$. Symmetry equivalent atoms were generated through their respective symmetry elements $(\mathrm{i}=-\mathrm{x}+1$, $-\mathrm{y}+1,-\mathrm{z}+1)$.

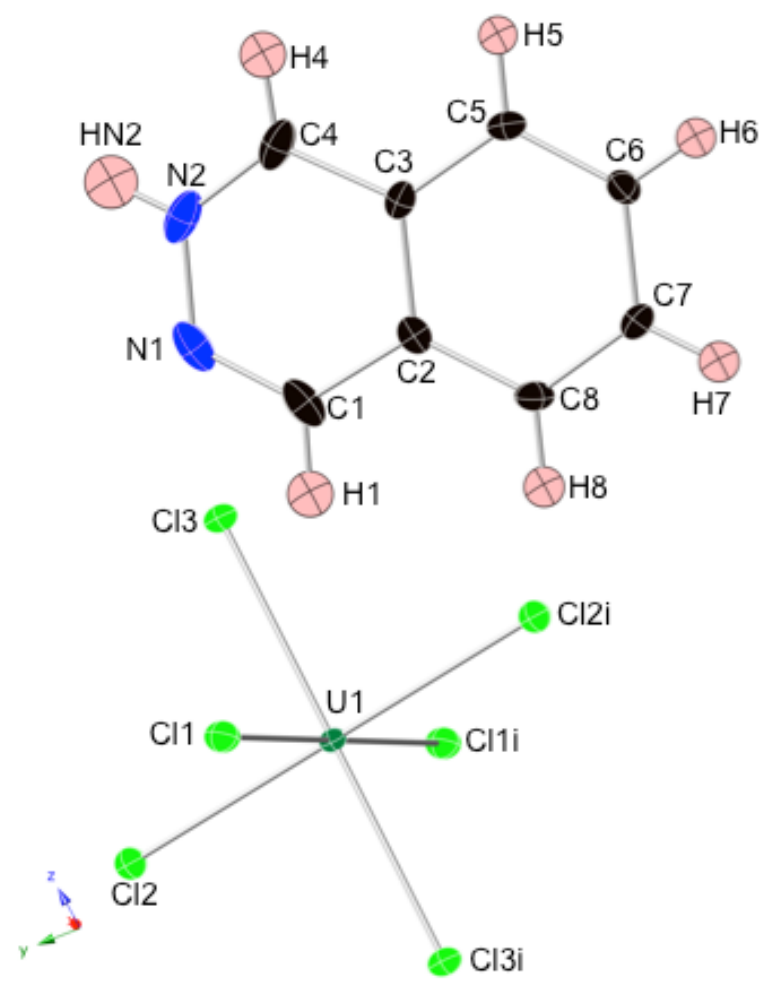

Figure S12. Thermal ellipsoid plot (50\% probability level) of (HPhthal) $)_{2} \mathbf{U C l}_{6}$ at $100 \mathrm{~K}$. Symmetry equivalent atoms were generated through their respective symmetry elements $(\mathrm{i}=-\mathrm{x}+1$, $-\mathrm{y}+1,-\mathrm{z})$. 


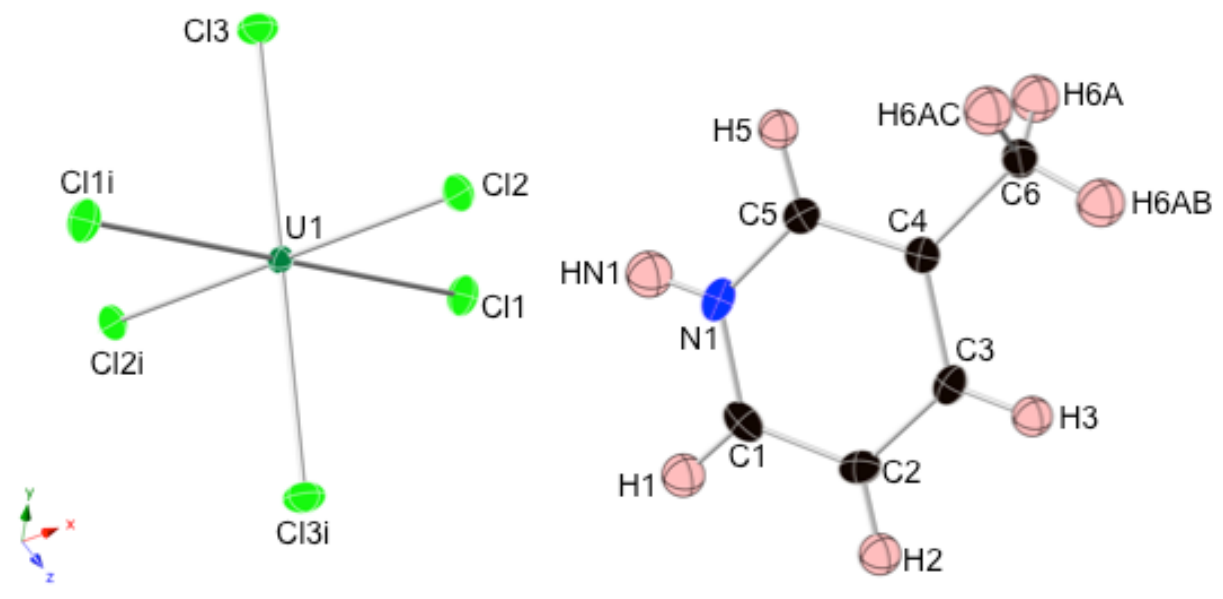

Figure S13. Thermal ellipsoid plot $\left(50 \%\right.$ probability level) of $(\mathbf{3}-\mathbf{M e P y H})_{2} \mathbf{U C l}_{\mathbf{6}}$ at $100 \mathrm{~K}$. Symmetry equivalent atoms were generated through their respective symmetry elements $(\mathrm{i}=-\mathrm{x},-$ $\mathrm{y}+1,-\mathrm{z}+1 / 2)$.
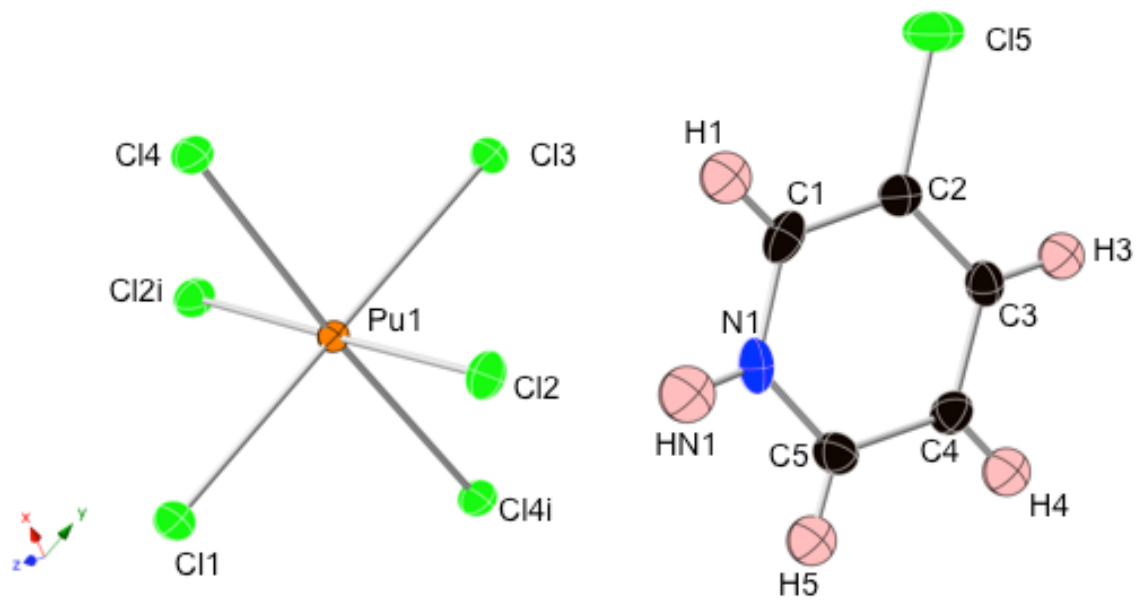

Figure S14. Thermal ellipsoid plot (50\% probability level) of (3-CIPyH) ${ }_{2} \mathbf{P u C l}_{6}$ at $100 \mathrm{~K}$. Symmetry equivalent atoms were generated through their respective symmetry elements $(i=-x+1, y,-z+3 / 2)$. 

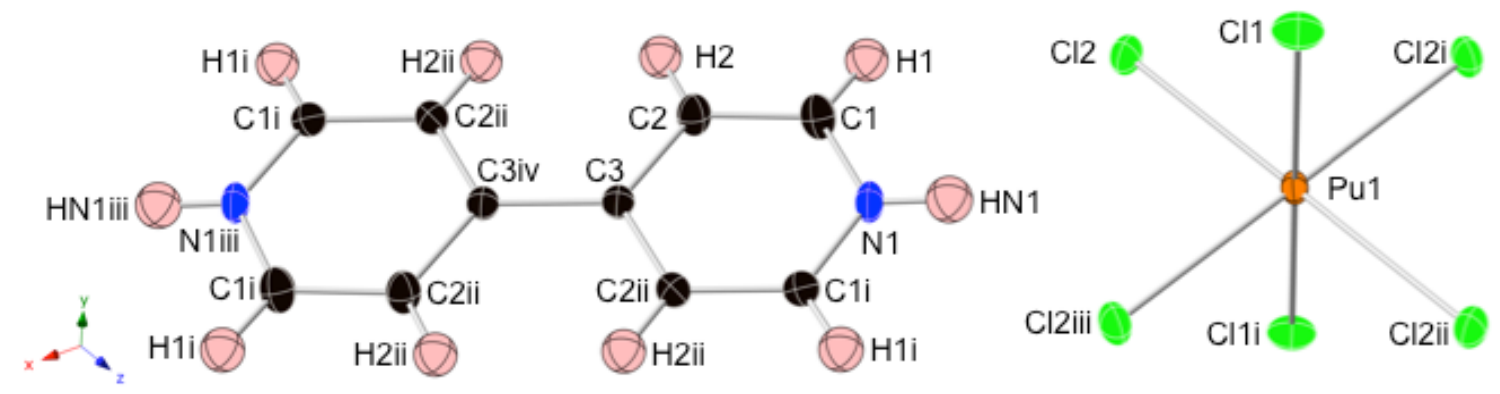

Figure S15. Thermal ellipsoid plot (50\% probability level) of $\left(\mathbf{H}_{2} \mathbf{b i p y}\right) \mathbf{P u C l} \mathbf{C l}_{6}$ at $100 \mathrm{~K}$. Symmetry equivalent atoms were generated through their respective symmetry elements $(\mathrm{i}=-\mathrm{x}+1,-\mathrm{y}+1,-\mathrm{z}+1, \mathrm{ii}=-\mathrm{x}+1, \mathrm{y},-\mathrm{z}+1, \mathrm{iii}=\mathrm{x},-\mathrm{y}+1, \mathrm{z}, \mathrm{iv}=-\mathrm{x}+2,-\mathrm{y}+1,-\mathrm{z})$.

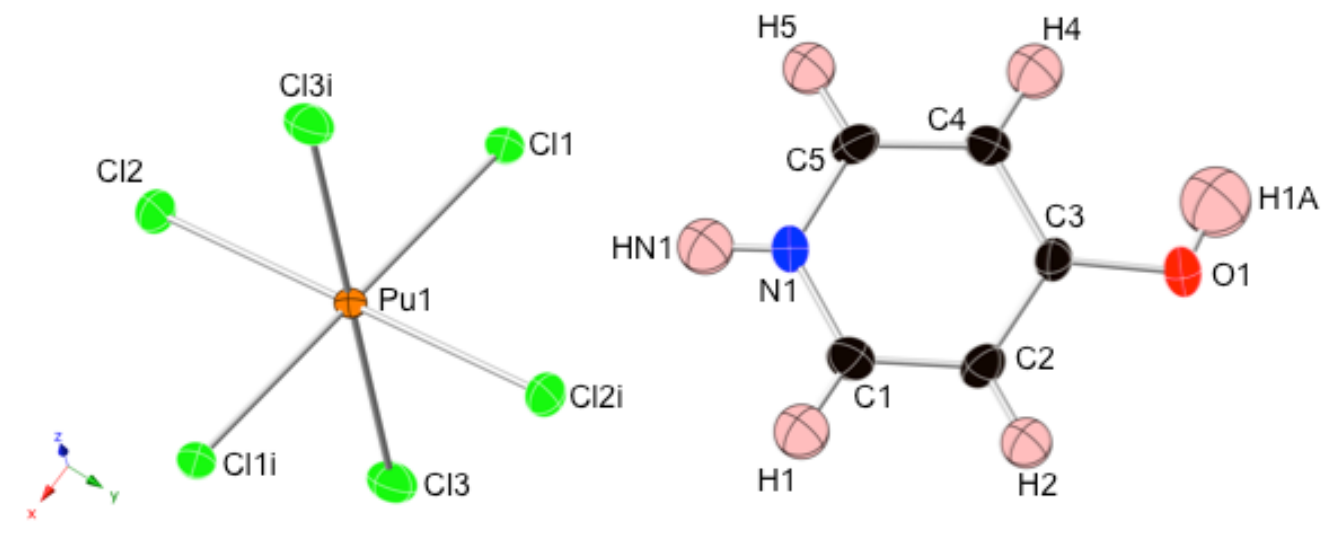

Figure S16. Thermal ellipsoid plot (50\% probability level) of (4-OHPyH) ${ }_{2} \mathbf{P u C l}_{\mathbf{6}}$ at $100 \mathrm{~K}$. Symmetry equivalent atoms were generated through their respective symmetry elements $(\mathrm{i}=-\mathrm{x}+2,-\mathrm{y}+1,-\mathrm{z}+1)$. 


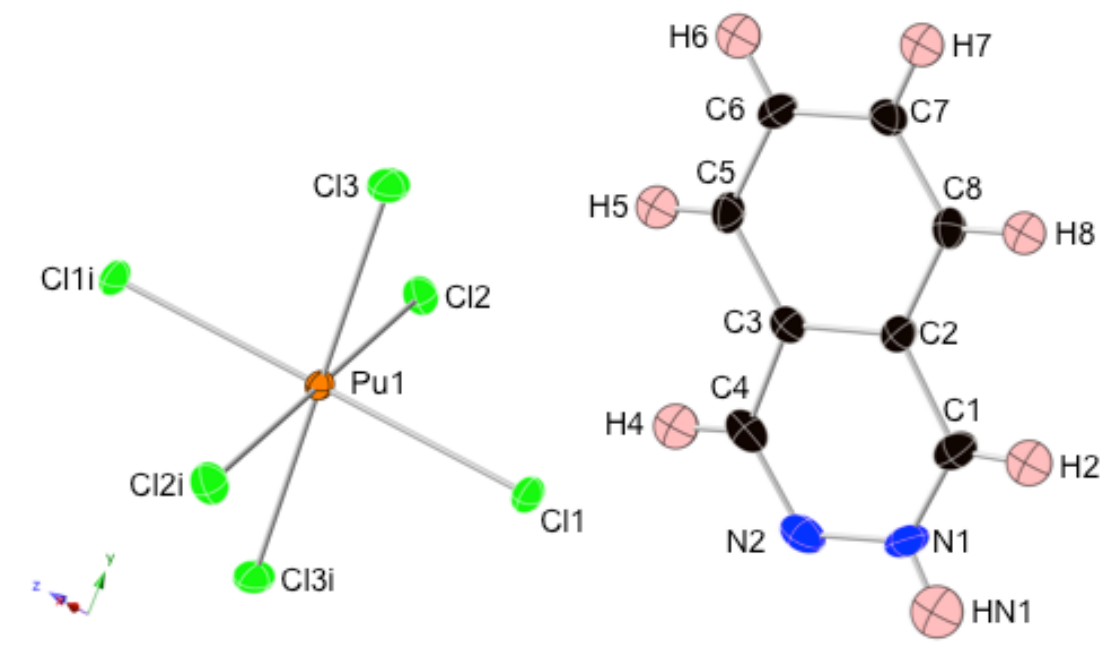

Figure S17. Thermal ellipsoid plot (50\% probability level) of (HPhthal) $\mathbf{2}_{\mathbf{2}} \mathbf{P u C l} \mathbf{l}_{\mathbf{6}}$ at $100 \mathrm{~K}$. Symmetry equivalent atoms were generated through their respective symmetry elements $(\mathrm{i}=-\mathrm{x}+1,-\mathrm{y},-\mathrm{z}+2)$.

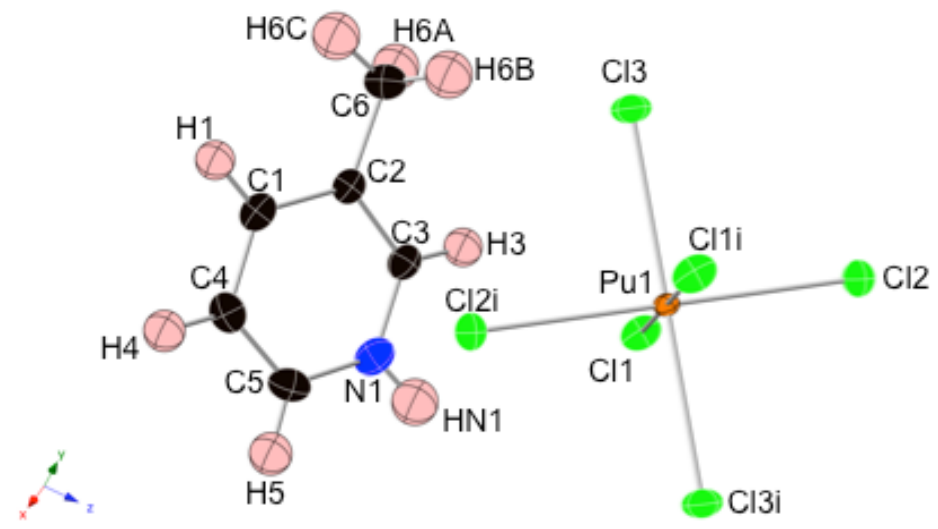

Figure S18. Thermal ellipsoid plot (50\% probability level) of (3-MePyH) $)_{\mathbf{2}} \mathbf{P u C l}_{\mathbf{6}}$ at $100 \mathrm{~K}$. Symmetry equivalent atoms were generated through their respective symmetry elements $(\mathrm{i}=-\mathrm{x},-\mathrm{y},-\mathrm{z})$.

\section{Structure Descriptions}

Supramolecular Structure Descriptions.

The structures of the compounds reported herein adopt supramolecular extended networks that result from noncovalent interactions including hydrogen bonding, halogen bonding, and $\pi-\pi$ stacking interactions. To differentiate between various hydrogen bonding interactions, the notation in Table S1 were used the hydrogen bond donors and acceptors. For $\pi-\pi$ interactions, $\mathrm{C}_{\mathrm{g}} \cdots \mathrm{C}_{\mathrm{g}}$ distances and slip angles $(\beta)$ correspond to the distance between ring centroids and angle formed between $\mathrm{C}_{\mathrm{g}}$ and the plane normal to $\mathrm{C}_{\mathrm{g}}$. 
Table S1. Notation used to denote the donor/acceptor atoms in hydrogen bonding interactions.

\begin{tabular}{|c|c|c|}
\hline Subscript & Donor/Acceptor Identity & Example \\
\hline Th, U, Pu, An & $\begin{array}{c}\text { Donor/acceptor is bound to metal center (Th, U, Pu, or An for } \\
\text { isomorphous compounds) }\end{array}$ & $\mathrm{O}_{\mathrm{Th}}-\mathrm{H} \cdots \mathrm{Cl}_{\mathrm{Th}}$ \\
\hline $\mathrm{R}$ & Donor is from the N-heterocycle & $\mathrm{N}_{\mathrm{R}}-\mathrm{H} \cdots \mathrm{Cl}_{\mathrm{L}}$ \\
\hline $\mathrm{L}$ & Donor/acceptor resides in the crystal lattice & $\mathrm{N}_{\mathrm{R}}-\mathrm{H} \cdots \mathrm{Cl}_{\mathrm{L}}$ \\
\hline
\end{tabular}

Compound Th-1, $\left[\mathrm{Th}\left(\mathrm{H}_{2} \mathrm{O}\right)_{6} \mathrm{Cl}_{3}\right] \mathrm{Cl} \cdot(3-\mathrm{ClPyH} \cdot \mathrm{Cl})$. As shown in Figures $\mathrm{S} 19 \mathrm{a} / \mathrm{S} 19 \mathrm{~b}, \mathrm{O}_{\mathrm{Th}}-\mathrm{H} \cdots \mathrm{Cl}_{\mathrm{Th}}$ and $\mathrm{O}_{\mathrm{Th}}-\mathrm{H} \cdots \mathrm{Cl}_{\mathrm{L}}$ interactions link the mononuclear units into "thick" two-dimensional sheets that propagate in the (001) plane. $\mathrm{N}_{\mathrm{R}}-\mathrm{H} \cdots \mathrm{Cl}_{\mathrm{L}}$ interactions between the 3-chloropyridinium cations and outer sphere chloride ions as well as $\mathrm{Cl}_{\mathrm{R}} \cdots \mathrm{Cl}_{\mathrm{Th}}$ interactions between the $\mathrm{Cl}$ of the $3-\mathrm{ClPyH}$ and the thorium bound $\mathrm{Cl}$ further connect the units into a 3-D supramolecular network. No significant $\pi-\pi$ stacking interactions are present in the structure.

(a)

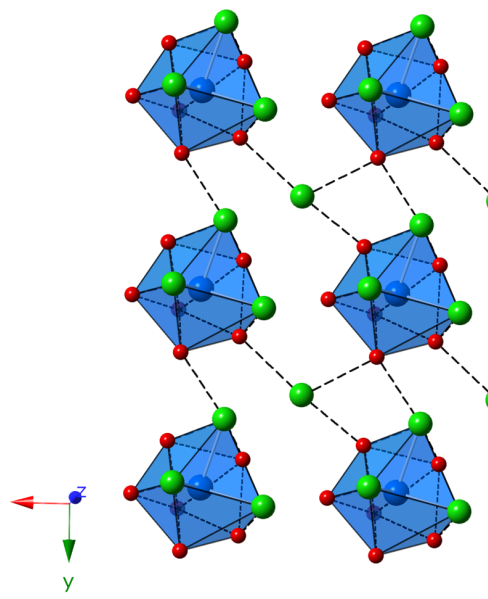

\section{(a)}

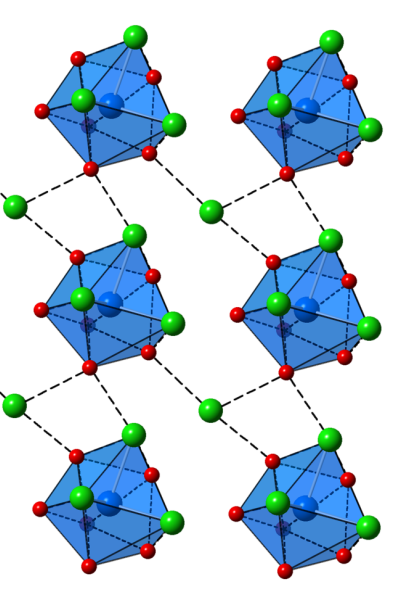

(b)

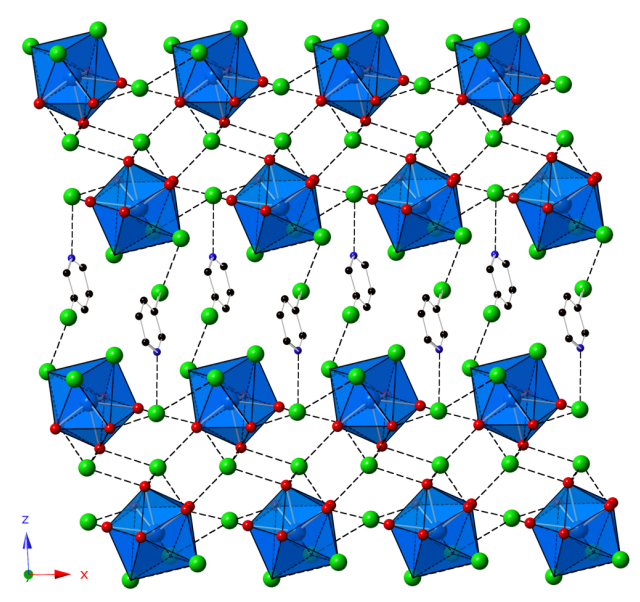

Figure S19. Illustration of (a) sheet formed through $\mathrm{O}_{\mathrm{Th}}-\mathrm{H} \cdots \mathrm{Cl}_{\mathrm{Th} / \mathrm{L}}$ interactions and (b) supramolecular network formed through $\mathrm{N}_{\mathrm{R}}-\mathrm{H} \cdots \mathrm{Cl}_{\mathrm{L}}$ and $\mathrm{Cl}_{\mathrm{R}} \cdots \mathrm{Cl}_{\mathrm{Th}}$ interactions. Noncovalent interactions are shown as dashed lines. Hydrogen atoms have been omitted for clarity. ( $\mathrm{Th}=$ light blue, $\mathrm{O}=$ red, $\mathrm{Cl}=$ green, $\mathrm{N}=$ dark blue, $\mathrm{C}=$ black).

Compound An-2 $(\mathrm{An}=\mathrm{Th}, \mathrm{U}),\left[\mathrm{An}\left(\mathrm{H}_{2} \mathrm{O}\right)_{5} \mathrm{Cl}_{4}\right] \cdot\left(\mathrm{H}_{2}\right.$ bipy $\left.\cdot 2 \mathrm{Cl}\right) \cdot \mathrm{H}_{2} \mathrm{O}$. The metal bound chloride and water molecules of the mononuclear $\mathrm{An}\left(\mathrm{H}_{2} \mathrm{O}\right)_{5} \mathrm{Cl}_{4}$ units engage in $\mathrm{O}_{\mathrm{Th}}-\mathrm{H} \cdots \mathrm{O}_{\mathrm{L}}$ and $\mathrm{O}_{\mathrm{Th}}-\mathrm{H} \cdots \mathrm{Cl}_{\mathrm{Th}}$ hydrogen bonding interactions with the lattice water molecules to form 2-dimensional supramolecular sheets that propagate in the (001) plane (Figure S20b). A summary of the hydrogen bonding interactions is provided in the Table S5/S10. The $\mathrm{H}_{2}$ bipy form bifurcated hydrogen bonding interactions with free $\mathrm{Cl}^{-}$ions, that together with weak offset $\pi-\pi$ stacking interactions form $\mathrm{H}_{2}$ bipy.2Cl sheets (Figure S20c). Representative $\mathrm{N}_{\mathrm{R}}-\mathrm{H} \cdots \mathrm{Cl}_{\mathrm{L}}$ and $\angle \mathrm{N}_{\mathrm{R}}-\mathrm{H} \cdots \mathrm{Cl}_{\mathrm{L}}$ are 3.181(3) $\AA$ and $132.9(3)^{\circ}$ for Th-2 and 3.173(2) $\AA$ and $132^{\circ}$ for $\mathbf{U}-2$. Minimum $\mathrm{C}_{\mathrm{g}} \cdots \mathrm{C}_{\mathrm{g}}$ distances and slip angles are 3.918(2) $\AA$ and $24.1^{\circ}$ for Th-2 and 3.890(2) $\AA$ and $24.2^{\circ}$ for $\mathbf{U}-2$. 
(a)

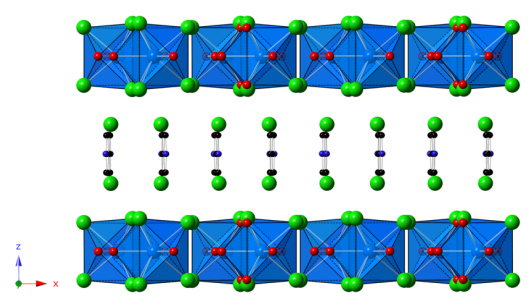

(b)

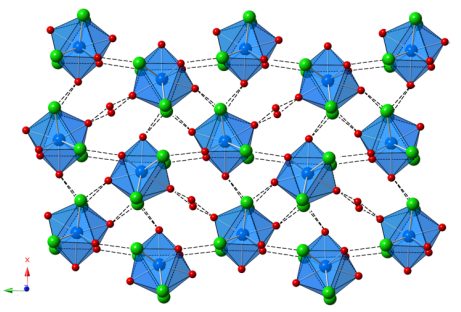

(c)

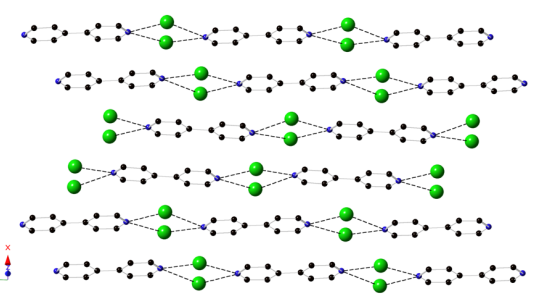

Figure S20. (a) Packing diagram of An-2 highlighting the alternating sheets of $\left[\mathrm{An}\left(\mathrm{H}_{2} \mathrm{O}\right)_{5} \mathrm{Cl}_{4}\right] \cdot \mathrm{H}_{2} \mathrm{O}$ and $\mathrm{H}_{2}$ bipy.2Cl. (b) polyhedral representation of the $\left[\mathrm{An}\left(\mathrm{H}_{2} \mathrm{O}\right)_{5} \mathrm{Cl}_{4}\right] \cdot \mathrm{H}_{2} \mathrm{O}$ sheets and (c) illustration of the $\mathrm{H}_{2}$ bipy.2 $\mathrm{Cl}$ two dimensional network. Hydrogen atoms have been omitted for clarity. ( $\mathrm{Th} / \mathrm{U}=$ light blue, $\mathrm{O}=\mathrm{red}, \mathrm{Cl}=$ green, $\mathrm{N}=$ dark blue, $\mathrm{C}=$ black).

Compound An-3 $(\mathrm{An}=\mathrm{Th}, \mathrm{U}),\left[\mathrm{An}\left(\mathrm{H}_{2} \mathrm{O}\right)_{4} \mathrm{Cl}_{4}\right] \cdot 2(4-\mathrm{OHPyH} \cdot \mathrm{Cl})$. The neutral $\left[\mathrm{An}\left(\mathrm{H}_{2} \mathrm{O}\right)_{4} \mathrm{Cl}_{4}\right]$ units form supramolecular sheets in (010) by way of $\mathrm{N}_{\mathrm{R}}-\mathrm{H}^{\cdots} \cdots \mathrm{Cl}_{\mathrm{An}}$ and $\mathrm{O}_{\mathrm{R}}-\mathrm{H} \cdots \mathrm{O}_{\mathrm{An}}$ hydrogen bonds and offset $\pi-\pi$ stacking interactions stemming from the 4-OHPyH cations (Figure S21). Additional $\mathrm{O}_{\mathrm{An}}-\mathrm{H} \cdots \mathrm{Cl}_{\mathrm{L}}$ and $\mathrm{Cl}_{\mathrm{L}} \cdots \mathrm{Cl}_{\mathrm{An}}$ interactions along the [010] give rise to a $3 \mathrm{D}$ supramolecular assembly.
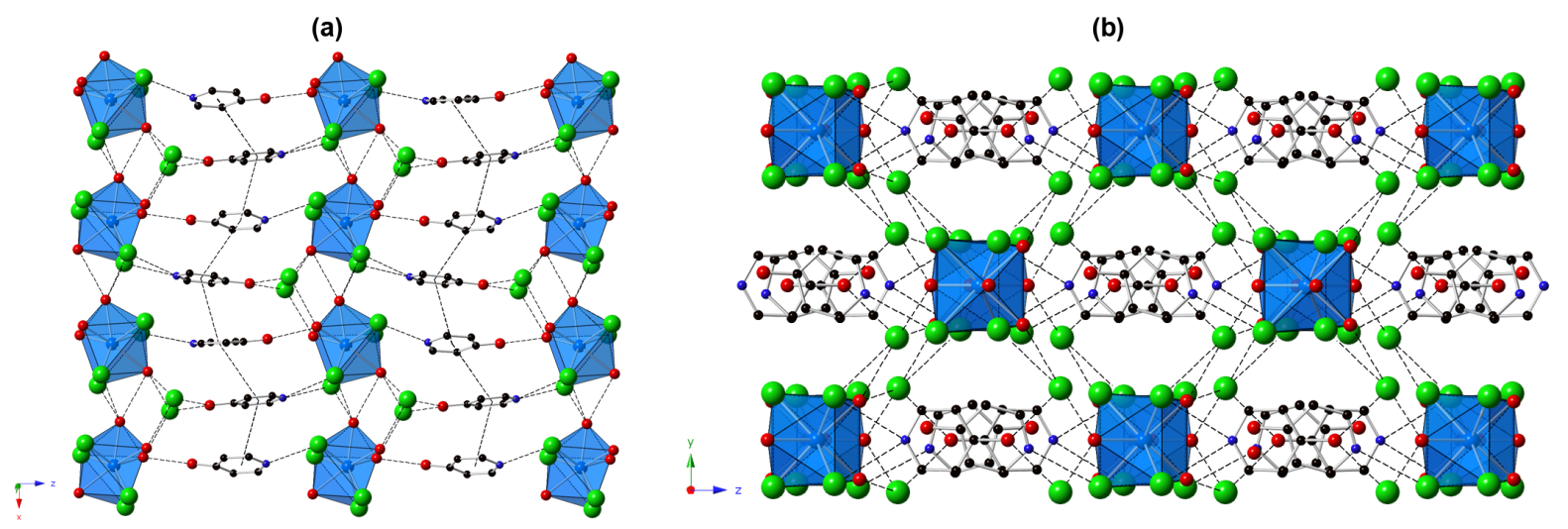

Figure S21. (a) Polyhedral representation of An-3 showing 2-dimensional sheets formed via hydrogen bonding and $\pi-\pi$ stacking interactions that extend in the (010) plane. (b) Packing diagram of An-3 viewed down the [100]; the sheets in (a) are connected along the [010] via $\mathrm{O}_{\mathrm{An}^{-}}$ $\mathrm{H} \cdots \mathrm{Cl}_{\mathrm{L}}$ and $\mathrm{Cl}_{\mathrm{An}} \cdots \mathrm{Cl}_{\mathrm{L}}$ interactions to form an overall 3-D supramolecular assembly. Hydrogen atoms have been omitted for clarity. $(\mathrm{Th} / \mathrm{U}=$ light blue, $\mathrm{O}=$ red, $\mathrm{Cl}=$ green, $\mathrm{N}=$ dark blue, $\mathrm{C}=$ black).

Compound Th-4, $\left[\mathrm{Th}\left(\mathrm{H}_{2} \mathrm{O}\right)_{7} \mathrm{Cl}_{2}\right] \mathrm{Cl}_{2} \cdot 2 \mathrm{H}_{2} \mathrm{O} \cdot(\mathrm{HPhthal} \cdot \mathrm{Cl})$. As shown in Figure S22a, $\mathrm{O}_{\mathrm{Th}}-\mathrm{H} \cdots \mathrm{Cl}_{\mathrm{L}}$ and $\mathrm{O}_{\mathrm{Th}}-\mathrm{H} \cdots \mathrm{O}_{\mathrm{L}}$ hydrogen bonding interactions between the $\left[\mathrm{Th}\left(\mathrm{H}_{2} \mathrm{O}\right)_{7} \mathrm{Cl}_{2}\right]^{2+}$ mononuclear units and the two chloride ions and two water molecules link the Th structural units into "thick" two dimensional sheets that propagate in the (001) plane. HPhthal cations reside in the interlayer spacing and form $\mathrm{N}_{\mathrm{R}}-\mathrm{H} \cdots \mathrm{Cl}_{\mathrm{L}}$ hydrogen bonding interactions with the lattice chloride ions; offset $\pi-\pi$ stacking interactions link the HPhthal along [100]. 
(a)

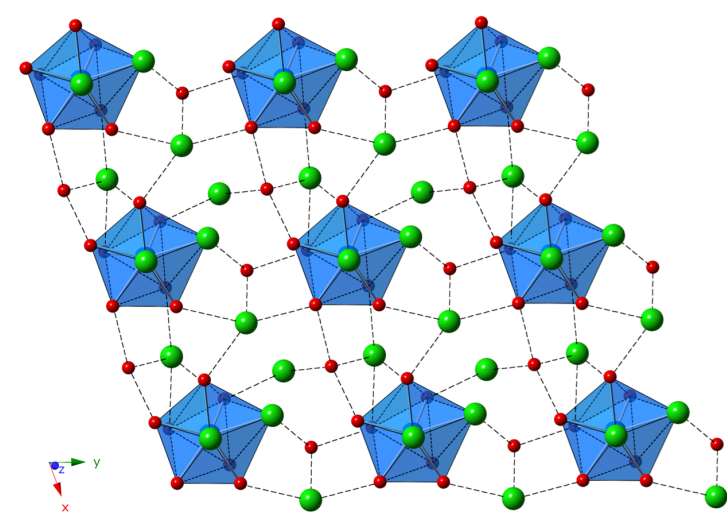

(b)

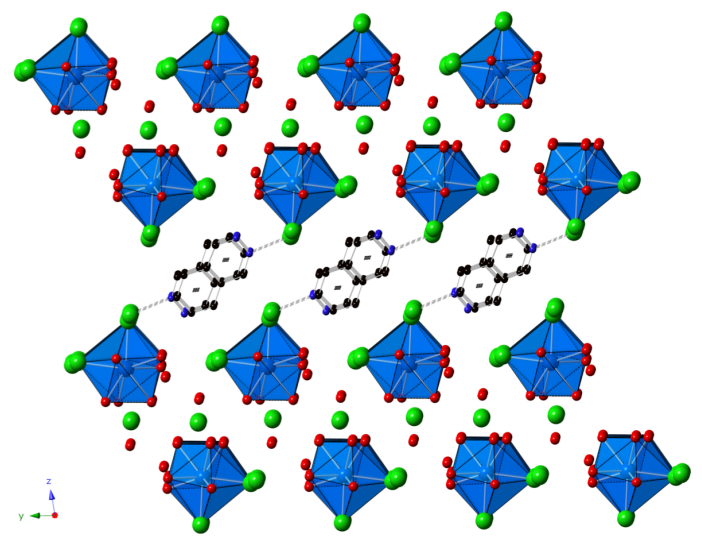

Figure S22. (a) Illustration of the supramolecular sheets in Th-4 formed through H-bonding interactions. (b) Packing diagram of Th-4 viewed down the [100]. Hydrogen atoms have been omitted for clarity. ( $\mathrm{Th}=$ light blue, $\mathrm{O}=\mathrm{red}, \mathrm{Cl}=$ green, $\mathrm{N}=$ dark blue, $\mathrm{C}=$ black).

Compound Th-5, $\left[\mathrm{Th}\left(\mathrm{H}_{2} \mathrm{O}\right)_{4} \mathrm{Cl}_{4}\right] \cdot 2(3-\mathrm{MePyH} \cdot \mathrm{Cl})$. Overall, the structure adopts a 3-dimensional supramolecular network that results from $\mathrm{O}_{\mathrm{Th}}-\mathrm{H} \cdots \mathrm{Cl}_{\mathrm{L}}$ hydrogen bonding interactions between the Th bound water molecules and the outer coordination sphere chloride anions; shortest $\mathrm{O}_{\mathrm{Th}^{-}}$ $\mathrm{H} \cdots \mathrm{Cl}_{\mathrm{L}}$ distances and $\angle \mathrm{O}_{\mathrm{Th}}-\mathrm{H} \cdots \mathrm{Cl}_{\mathrm{L}}$ are 3.009(3) $\AA$ and $170(4)^{\circ}$. As shown in Figure S23, the 3$\mathrm{MePyH}$ cations sit in channels that propagate along the [010] and engage in hydrogen bonding with the free chloride ions of the 3-dimensional $\left[\mathrm{Th}\left(\mathrm{H}_{2} \mathrm{O}\right)_{4} \mathrm{Cl}_{4}\right] \cdot 2 \mathrm{Cl}$ assembly. Offset $\pi-\pi$ stacking interactions further connect the 3-MePyH cations along [010] with minimum $\mathrm{C}_{\mathrm{g}} \cdots \mathrm{C}_{\mathrm{g}}$ distances and slip angles of 3.390(1) $\AA$ and $13.8^{\circ}$.

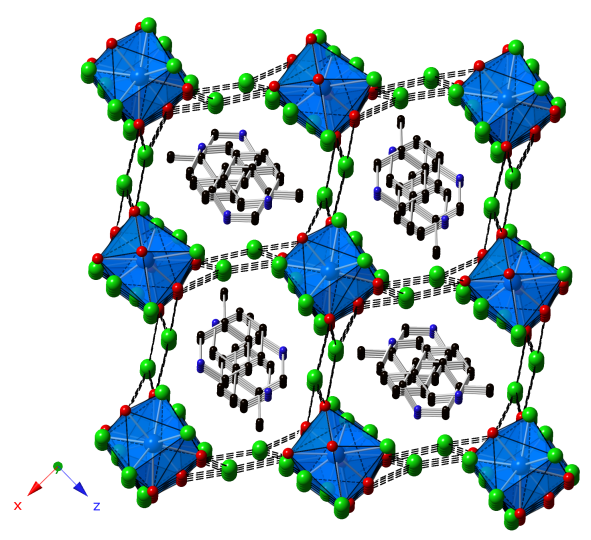

Figure S23. Polyhedral representation of Th-5 illustrating the supramolecular network formed via hydrogen bonding. 3-MePyH sit in the channels and charge balance the anionic supramolecular assembly. Hydrogen bonding interactions between $\mathrm{Th}-\mathrm{OH}_{2}$ and free chloride are highlighted as dashed lines. Hydrogen atoms have been omitted for clarity. (Th=light blue, $\mathrm{O}=$ red, $\mathrm{Cl}=$ green, $\mathrm{N}=$ dark blue, $\mathrm{C}=$ black). 
Compound An-6 $(\mathrm{An}=\mathrm{U}, \mathrm{Pu}),(3-\mathrm{ClPyH})_{2} \mathrm{AnCl}_{6}$. As shown in Figure S24, the anionic $\mathrm{AnCl}_{6}{ }^{2-}$ units form hydrogen bonding interactions with the 3-ClPyH cations; $\mathrm{N}_{\mathrm{R}}-\mathrm{H} \cdots \mathrm{Cl}_{\mathrm{An}}$ distances and $\angle \mathrm{N}_{\mathrm{R}}-\mathrm{H} \cdots \mathrm{Cl}_{\mathrm{An}}$ are 3.163(2) $\AA / 152(3)^{\circ}$ and 3.165(2) $\AA / 154(2)^{\circ}$ for $\mathbf{U}-6$ and Pu-6, respectively. These non-covalent interactions together with $\pi-\pi$ stacking interactions stitch the $\mathrm{AnCl}_{6}{ }^{2-}$ into chains that propagate along [00-1]. Relevant interaction distances are provided in the Tables S8/S16.

(a)

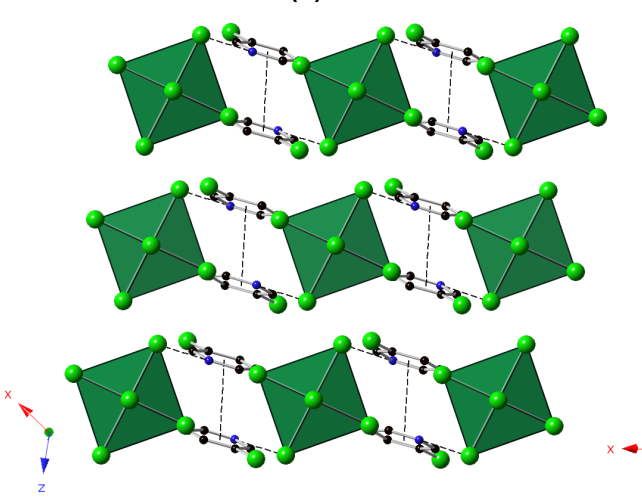

(b)

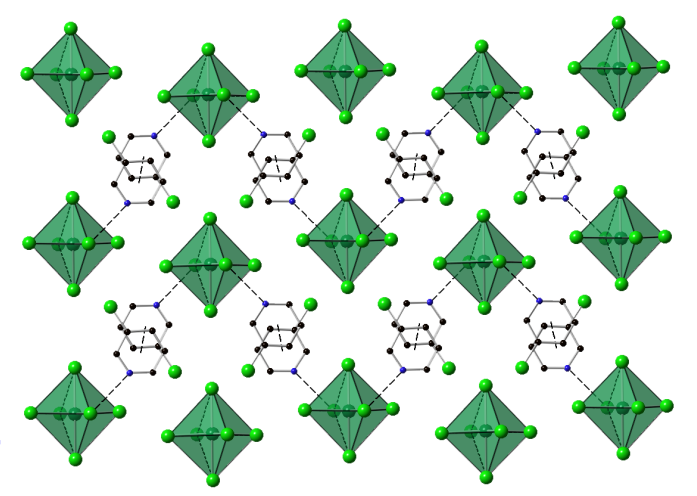

Figure S24. Illustration of the undulating chains observed in An-6 that result from hydrogen bonding interactions between the $\mathrm{AnCl}_{6}{ }^{2-}$ and $3-\mathrm{ClPyH}$ cations and $\pi-\pi$ stacking interactions. Hydrogen atoms have been omitted for clarity. ( $\mathrm{U} / \mathrm{Pu}=$ dark green, $\mathrm{Cl}=$ green, $\mathrm{N}=$ dark blue, $\mathrm{C}=$ black).

Compound An-7 (An = U, Pu), $\left(\mathrm{H}_{2}\right.$ bipy $) \mathrm{AnCl}_{6}$. The $\mathrm{AnCl}_{6}{ }^{2-}$ propagate along the [-101] direction via bifurcated hydrogen bonding interactions with the bipyridinium cations as shown in Figure $\mathrm{S} 25$. The bridging bifurcated hydrogen bonds are symmetric, with a $\mathrm{N}_{\mathrm{R}}-\mathrm{H} \cdots \mathrm{Cl}_{\mathrm{U}}$ distance of 3.294(2) $\AA$ and a $\angle \mathrm{N}_{\mathrm{R}}-\mathrm{H} \cdots \mathrm{Cl}_{\mathrm{U}}$ of $134.8(6)^{\circ}$ for $\mathbf{U}-7$. Plutonium adopts an isomorphous structure (Pu-7) with a $\mathrm{N}_{\mathrm{R}}-\mathrm{H} \cdots \mathrm{Cl}_{\mathrm{Pu}}$ distance of 3.293(2) $\AA$ and a $\angle \mathrm{N}_{\mathrm{R}}-\mathrm{H} \cdots \mathrm{Cl}_{\mathrm{Pu}}$ of $135.8(4)^{\circ}$. No significant $\pi-\pi$ stacking interactions are present in the crystal structure.

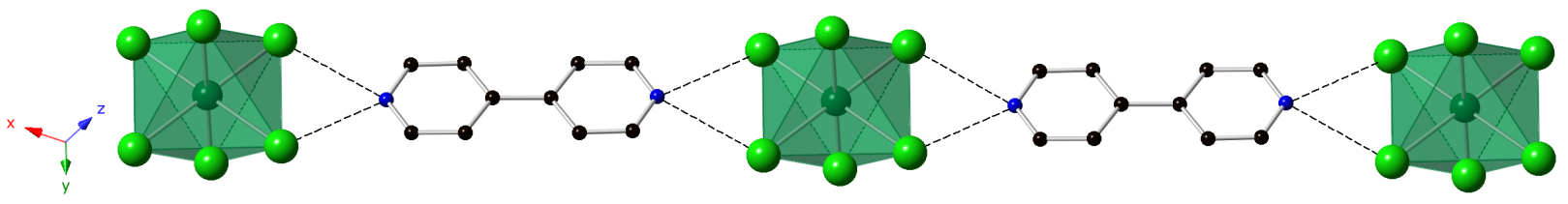

Figure S25. A chain motif resulting from bifurcating hydrogen bonding interactions between the $\mathrm{AnCl}_{6}{ }^{2-}$ and $\mathrm{H}_{2}$ bipy is observed in An-7. Hydrogen atoms have been omitted for clarity. $(\mathrm{U} / \mathrm{Pu}=$ dark green, $\mathrm{Cl}=$ green, $\mathrm{N}=$ dark blue, $\mathrm{C}=$ black $)$.

Compound $\mathbf{U - 8},\left[\mathrm{U}\left(\mathrm{H}_{2} \mathrm{O}\right)_{7} \mathrm{Cl}_{2}\right] \mathrm{Cl}_{2} \cdot 2 \mathrm{H}_{2} \mathrm{O}$. Extensive $\mathrm{O}_{\mathrm{U}}-\mathrm{H} \cdots \mathrm{Cl}_{\mathrm{L}}$ and $\mathrm{O}_{\mathrm{U}}-\mathrm{H} \cdots \mathrm{O}_{\mathrm{L}}$ hydrogen bonding interactions are present in the structure, linking the mononuclear $\left[\mathrm{U}\left(\mathrm{H}_{2} \mathrm{O}\right)_{7} \mathrm{Cl}_{2}\right]^{2+}$ units into an extended 3-dimensional network (Figure S26). Hydrogen bonding $\mathrm{O}_{\mathrm{U}}-\mathrm{H} \cdots \mathrm{O}_{\mathrm{L}}$ distances and $\angle \mathrm{O}_{\mathrm{U}}-\mathrm{H} \cdots \mathrm{O}_{\mathrm{L}}$ range from $2.717(3) \AA, 170(3)^{\circ}$ to $2.728(2) \AA, 176(3)^{\circ}$. The shortest $\mathrm{O}_{\mathrm{U}}-\mathrm{H} \cdots \mathrm{Cl}_{\mathrm{L}}$ 
distances and $\angle \mathrm{O}_{\mathrm{U}}-\mathrm{H} \cdots \mathrm{Cl}_{\mathrm{L}}$ are 3.060(2) $\AA$ and $172^{\circ}$. Other selected non-covalent interactions are listed in the Table S12.

(a)

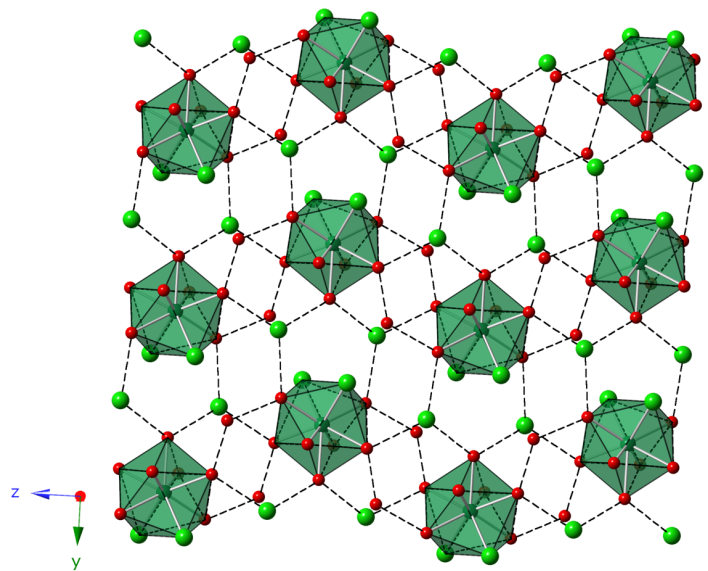

(b)

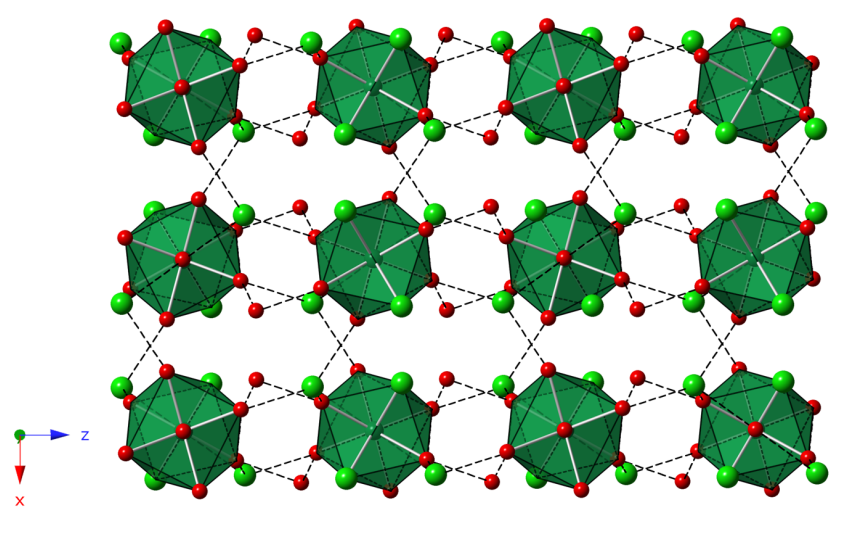

Figure S26. Packing diagram of U-8 viewed along (a) [100] and (b) [010] highlighting the 3dimensional supramolecular network that results from $\mathrm{O}_{U}-\mathrm{H} \cdots \mathrm{Cl}_{\mathrm{L}}$ and $\mathrm{O}_{U}-\mathrm{H} \cdots \mathrm{O}_{\mathrm{L}}$ hydrogen bonding interactions. Hydrogen atoms have been omitted for clarity. ( $\mathrm{U}=$ dark green, $\mathrm{O}=\mathrm{red}$, $\mathrm{Cl}=$ green $)$.

Compound An-9 $(\mathrm{An}=\mathrm{U}, \mathrm{Pu}),(4-\mathrm{OHPyH})_{2} \mathrm{AnCl}_{6}$. The $\mathrm{AnCl}_{6}{ }^{2-}$ dianions exhibit $\mathrm{N}_{\mathrm{R}}-\mathrm{H} \cdots \mathrm{Cl}_{\mathrm{An}}$ and $\mathrm{O}_{\mathrm{R}}-\mathrm{H} \cdots \mathrm{Cl}_{\text {An }}$ hydrogen bonding interactions with 4-OHPyH cations as highlighted in Figure S27. These noncovalent interactions together with $\pi-\pi$ stacking interactions result in a 3-dimensional supramolecular assembly. Uranium and plutonium adopt isomorphous structures (U-9 and Pu-9). Hydrogen bonding interactions, $\mathrm{N}_{\mathrm{R}}-\mathrm{H} \cdots \mathrm{Cl}_{\mathrm{U}}, \angle \mathrm{N}_{\mathrm{R}}-\mathrm{H} \cdots \mathrm{Cl}_{\mathrm{U}}$ and $\mathrm{O}_{\mathrm{R}}-\mathrm{H} \cdots \mathrm{Cl}_{\mathrm{U}}, \angle \mathrm{O}_{\mathrm{R}}-\mathrm{H} \cdots \mathrm{Cl}$ are 3.220(2) $\AA, 157(3)^{\circ}$ and 3.224(2) $\AA, 148(2)^{\circ}$, respectively, for U-9. For Pu-9, $\mathrm{N}_{\mathrm{R}}-\mathrm{H} \cdots \mathrm{Cl}_{\mathrm{Pu}}$ and $\angle \mathrm{N}_{\mathrm{R}}-\mathrm{H} \cdots \mathrm{Cl}_{\mathrm{Pu}}$ are $3.210(3) \AA$ and $148(3)^{\circ}$, respectively, while the shortest $\mathrm{O}_{\mathrm{R}}-\mathrm{H} \cdots \mathrm{Cl}_{\mathrm{Pu}}$ and $\angle \mathrm{O}_{\mathrm{R}^{-}}$ $\mathrm{H} \cdots \mathrm{Cl}_{\mathrm{Pu}}$ are $3.261(3) \AA$ and $148(3)^{\circ} . \mathrm{C}_{\mathrm{g}} \cdots \mathrm{C}_{\mathrm{g}}$ distances and slip angles are 3.582(1) $\AA$ and $10.5^{\circ}$ for U-9 and 3.562(2) $\AA$ and $6.9^{\circ}$ for Pu-9. 
(a)

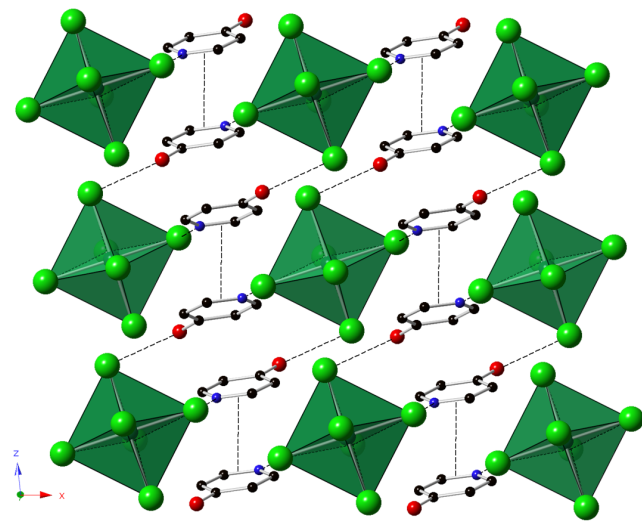

(b)

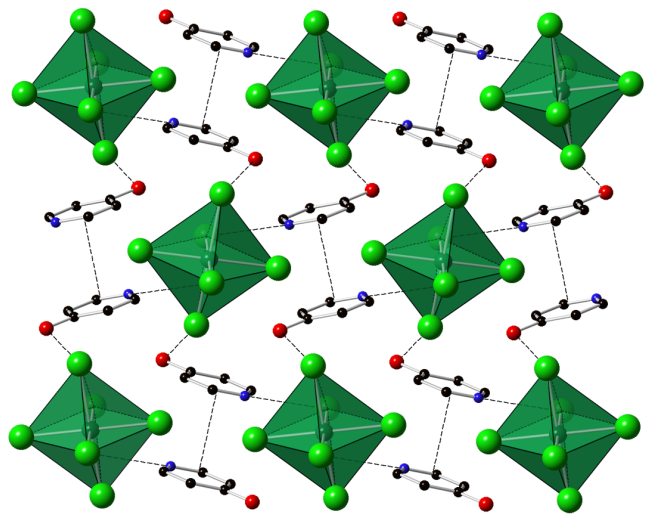

Figure S27. Polyhedral representation of the supramolecular assembly formed in An-9 through $\mathrm{N}_{\mathrm{R}}-\mathrm{H} \cdots \mathrm{Cl}_{\mathrm{An}}, \mathrm{O}_{\mathrm{R}}-\mathrm{H} \cdots \mathrm{Cl}_{\mathrm{An}}$ hydrogen bonding and $\pi-\pi$ stacking interactions. Hydrogen atoms have been omitted for clarity. ( $\mathrm{U} / \mathrm{Pu}=$ dark green, $\mathrm{O}=$ red, $\mathrm{Cl}=$ green, $\mathrm{N}=$ dark blue, $\mathrm{C}=$ black).

Compound An-10 $(\mathrm{An}=\mathrm{U}, \mathrm{Pu})$. As shown in Figure 28, the $\mathrm{AnCl}_{6}{ }^{2-}$ dianions engage in $\mathrm{N}_{\mathrm{R}^{-}}$ $\mathrm{H} \cdots \mathrm{Cl}_{\mathrm{An}}$ hydrogen bonding interactions with $\mathrm{HPhthal}$, that together with $\pi-\pi$ stacking interactions between $\mathrm{HPhthal}$ result in 2-dimensional sheets. Hydrogen bonding $\mathrm{N}_{\mathrm{R}}-\mathrm{H} \cdots \mathrm{Cl}_{\mathrm{U}}$ and $\angle \mathrm{N} R-\mathrm{H} \cdots \mathrm{Cl}_{\mathrm{U}}$ are 3.351(2) $\AA$ and 140(2) ${ }^{\circ}$, respectively, for $\mathbf{U}-10$ and 3.309(2) $\AA$ and 138(2) $\AA$, respectively, for Pu-10. Minimum $C_{g} \cdots C_{g}$ distances and slip angles are $3.817(1) \AA$ and $28.9^{\circ}$ for $\mathbf{U}-\mathbf{1 0}$ and 3.810(2) $\AA$ and $28.3^{\circ}$ for $\mathbf{P u - 1 0}$.

(a)

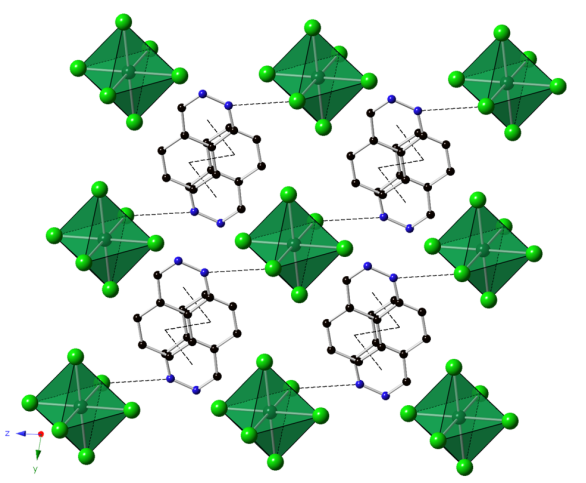

(b)

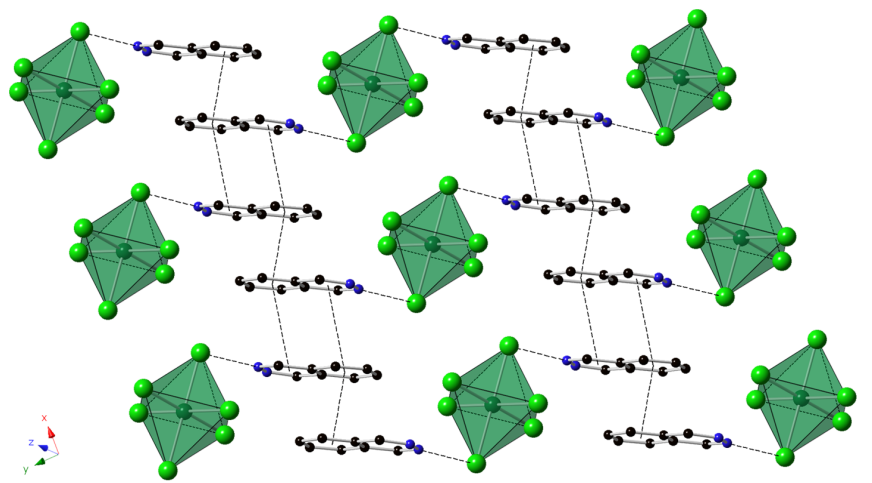

Figure S28. (a) Packing diagram of An-10 viewed down the [100]. (b) Illustration of the 2dimensional supramolecular network formed via $\mathrm{N}_{\mathrm{R}}-\mathrm{H} \cdots \mathrm{Cl}_{\mathrm{An}}$ hydrogen bonding and $\pi-\pi$ interactions. Hydrogen atoms have been omitted for clarity. $(\mathrm{U} / \mathrm{Pu}=\mathrm{dark}$ green, $\mathrm{Cl}=\mathrm{green}$, $\mathrm{N}=$ dark blue, $\mathrm{C}=$ black).

Compound An-11 $(\mathrm{An}=\mathrm{U}, \mathrm{Pu}),(3-\mathrm{MePyH})_{2} \mathrm{AnCl}_{6}$. The $\mathrm{AnCl}_{6}{ }^{2-}$ dianions exhibit $\mathrm{N}_{\mathrm{R}}-\mathrm{H} \cdots \mathrm{Cl}_{\mathrm{An}}$ hydrogen bonding interactions with $3-\mathrm{MePyH}$ cations, which further engage in $\pi-\pi$ stacking interactions to form the one-dimensional chains shown in Figure S29. Hydrogen bond $\mathrm{N}_{\mathrm{R}^{-}}$ $\mathrm{H} \cdots \mathrm{Cl}_{\mathrm{U}}$ distances and $\angle \mathrm{N}_{\mathrm{R}}-\mathrm{H} \cdots \mathrm{Cl}_{\mathrm{U}}$ are 3.208(2) and $152(2)^{\circ}$ for $\mathbf{U}-11$ and $3.201(3) \AA$ and 
150(2) ${ }^{\circ}$ for Pu-11. $C_{\mathrm{g}} \cdots \mathrm{C}_{\mathrm{g}}$ distances and slip angles are 3.701(1) $\AA$ and $23.3^{\circ}$ for $\mathbf{U}-\mathbf{1 1}$ and 3.716(2) $\AA$ and $23.5^{\circ}$ for Pu-11.

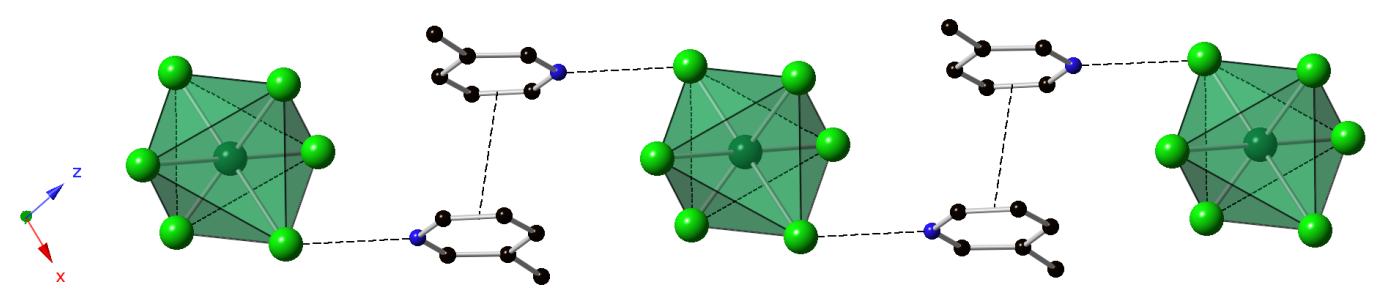

Figure S29. Illustration of the supramolecular network in An-11. $\mathrm{N}_{\mathrm{R}}-\mathrm{H} \cdots \mathrm{Cl}_{\mathrm{An}}$ hydrogen bonding and $\pi-\pi$ interactions of 3-MePyH connect the $\mathrm{AnCl}_{6}{ }^{2-}$ units into 1-dimensional chains that extend along the [-10-1]. Hydrogen atoms have been omitted for clarity. $(\mathrm{U} / \mathrm{Pu}=$ dark green, $\mathrm{Cl}=$ green, $\mathrm{N}=$ dark blue, $\mathrm{C}=$ black).

\section{Powder X-ray diffraction for Th and $U$ compounds}

Powder patterns were collected on the bulk reaction products and compared to the patterns calculated from single crystal X-ray diffraction data to confirm that the single crystals used for structure determination were representative of the bulk. With the exception of Th- 4 , the observed and calculated patterns showed relatively good agreement; however, peaks that could not be indexed to the title compounds were still observed. Consistent with these observations, the observed elemental composition obtained from combustion EA for Th-1-Th-5 did not agree within $<0.5 \%$ the calculated elemental composition. As Th(IV) salts are highly hygroscopic, it is likely that the compounds absorbed water during sample preparation thus resulting in the differences between the observed and calculated patterns. It cannot be ruled out; however, that there are unidentified phases.

For U compounds, the powder X-ray diffraction studies confirm the purity of the U phases that form $\mathrm{UCl}_{6}{ }^{2-}$ exclusively (i.e. U-6, U-10, and U-11). Elemental analyses were also performed on these phases. Bulk analyses were not performed on the remaining $U$ compounds that resulted in mixed products (i.e $\mathbf{U}-\mathbf{2}, \mathbf{U}-\mathbf{7}, \mathbf{U}-\mathbf{8}, \mathbf{U}-\mathbf{3}$, and $\mathbf{U}-\mathbf{9}$ ) due to the difficulty in separating these phases coupled with their instability in air. 


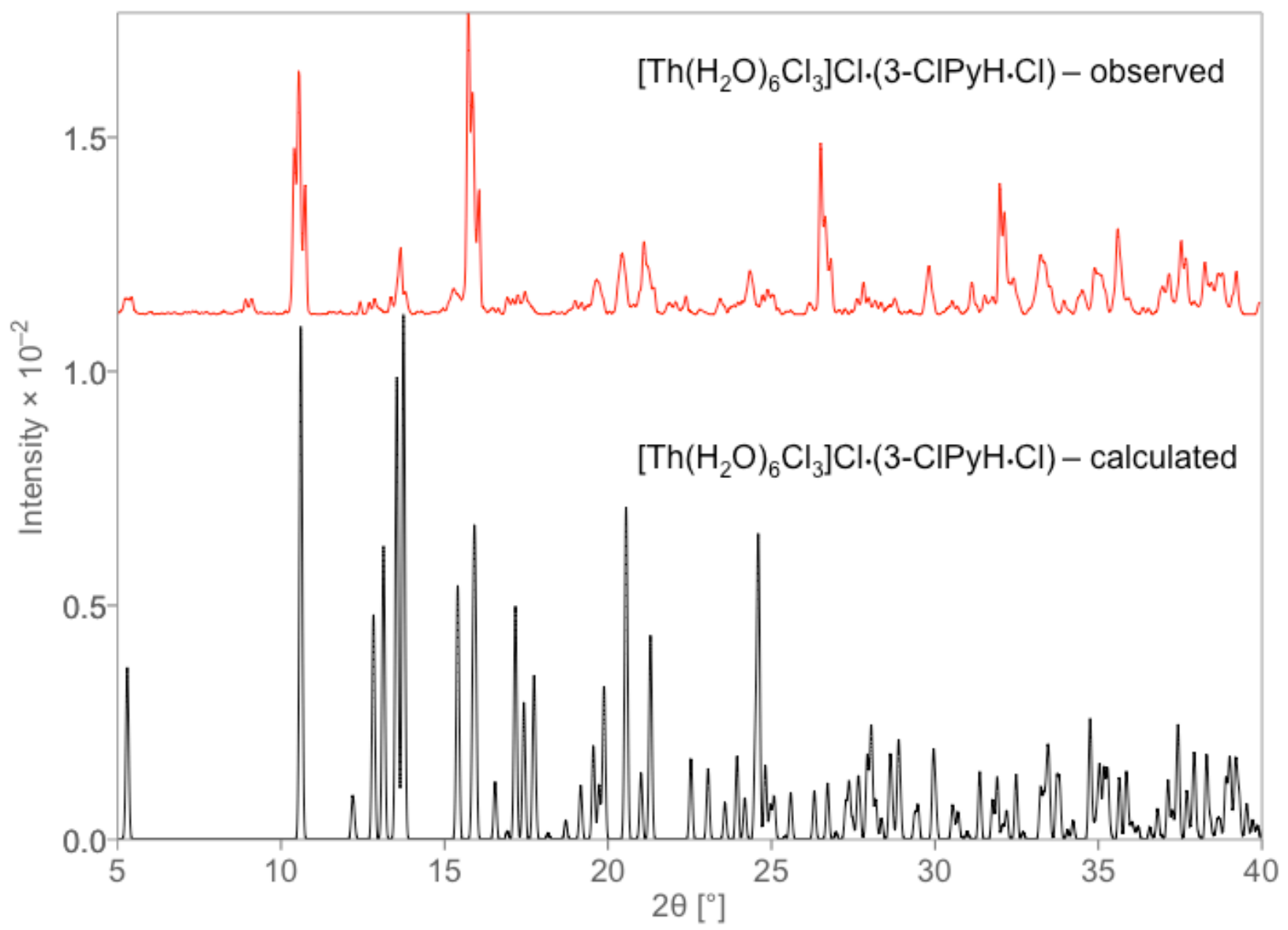

Figure S30. Powder X-ray diffraction pattern (collected with $\mathrm{Cu} \mathrm{K \alpha}$ radiation) observed for Th1 (red) overlaid with the pattern calculated from the single crystal structure at $100 \mathrm{~K}$ (black). 


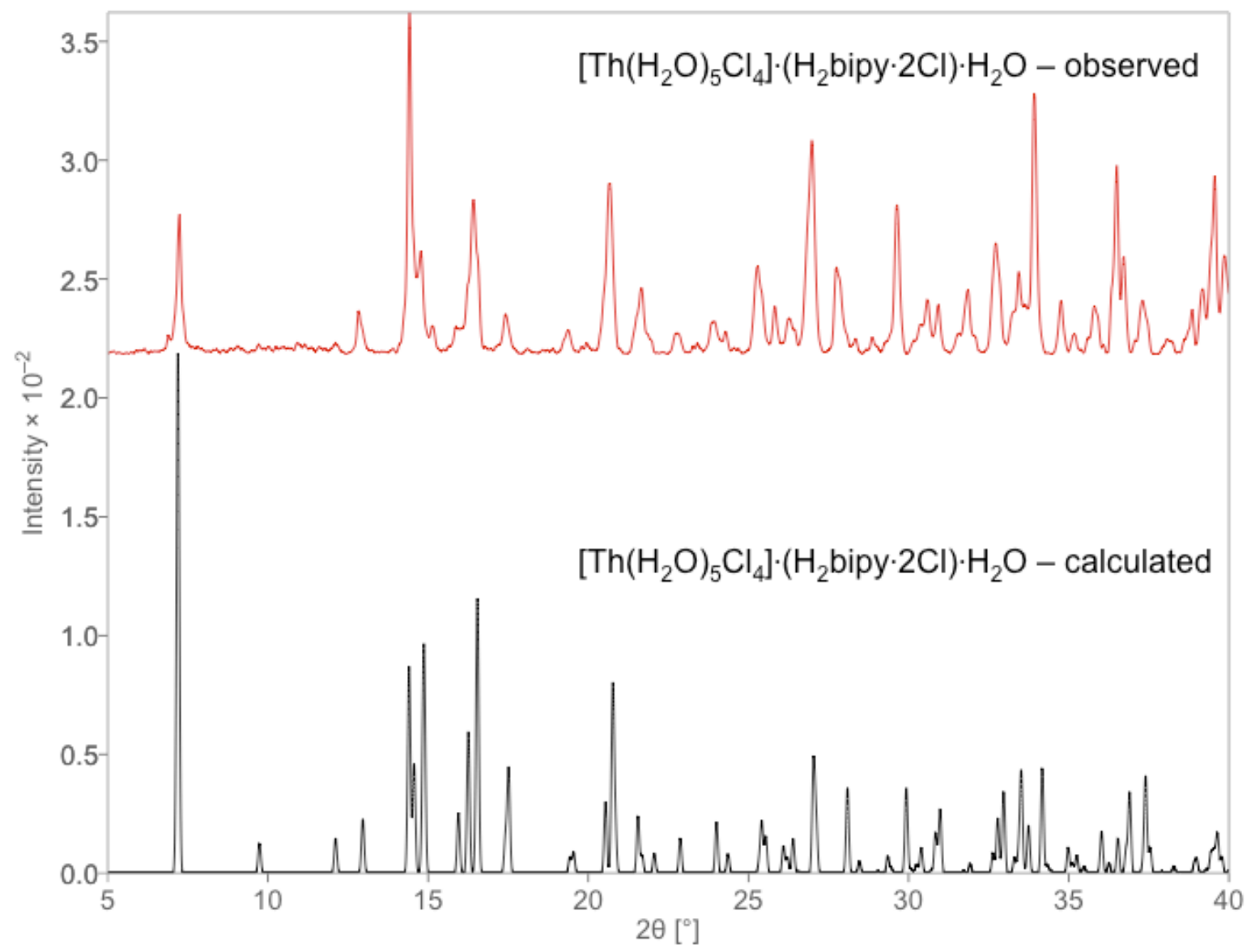

Figure S31. Powder X-ray diffraction pattern (collected with $\mathrm{Cu} \mathrm{K} \alpha$ radiation) observed for Th2 (red) overlaid with the pattern calculated from the single crystal structure at $100 \mathrm{~K}$ (black). 


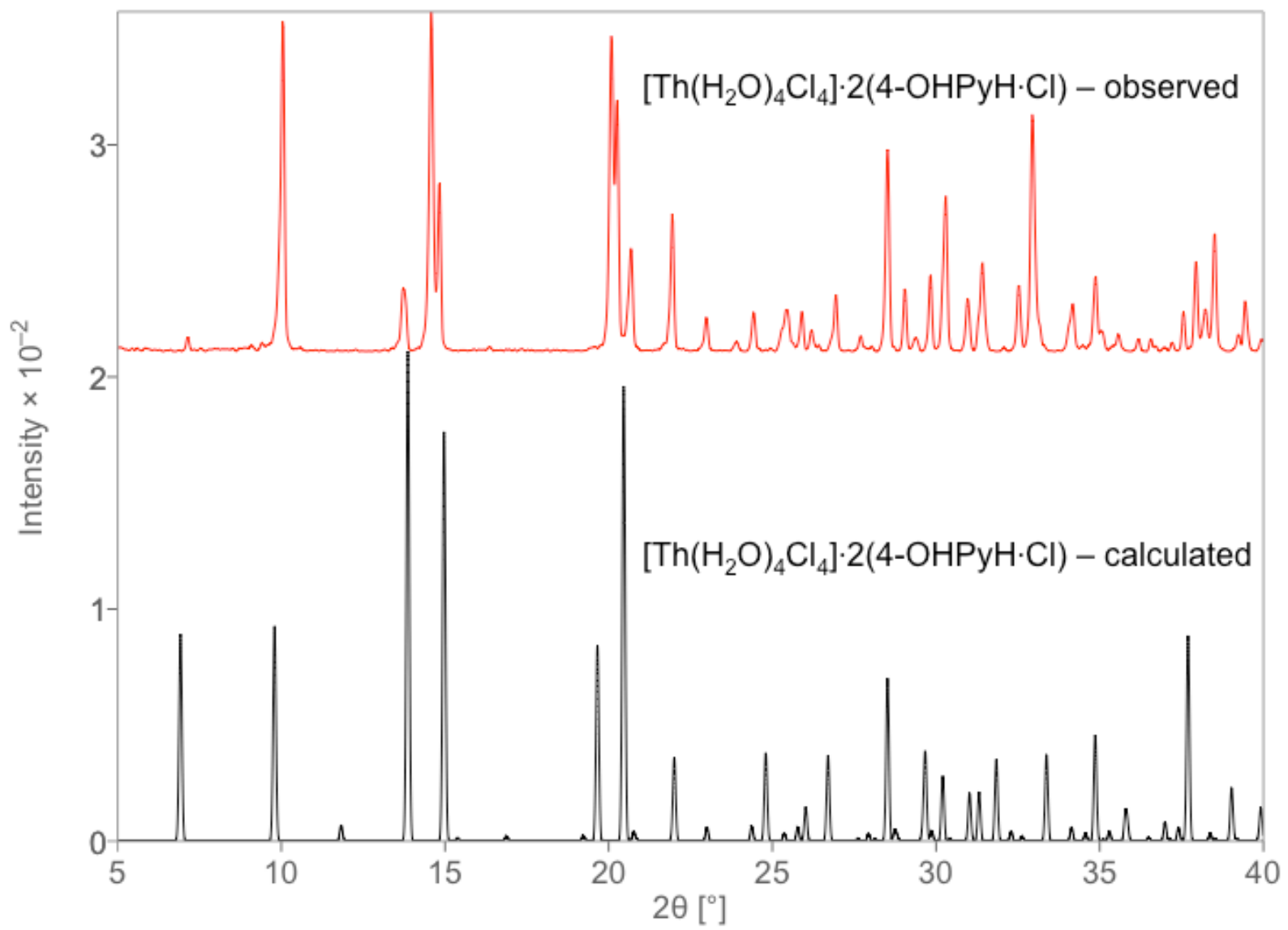

Figure S32. Powder X-ray diffraction pattern (collected with $\mathrm{Cu} \mathrm{K \alpha}$ radiation) observed for Th3 (red) overlaid with the pattern calculated from the single crystal structure at $100 \mathrm{~K}$ (black). 


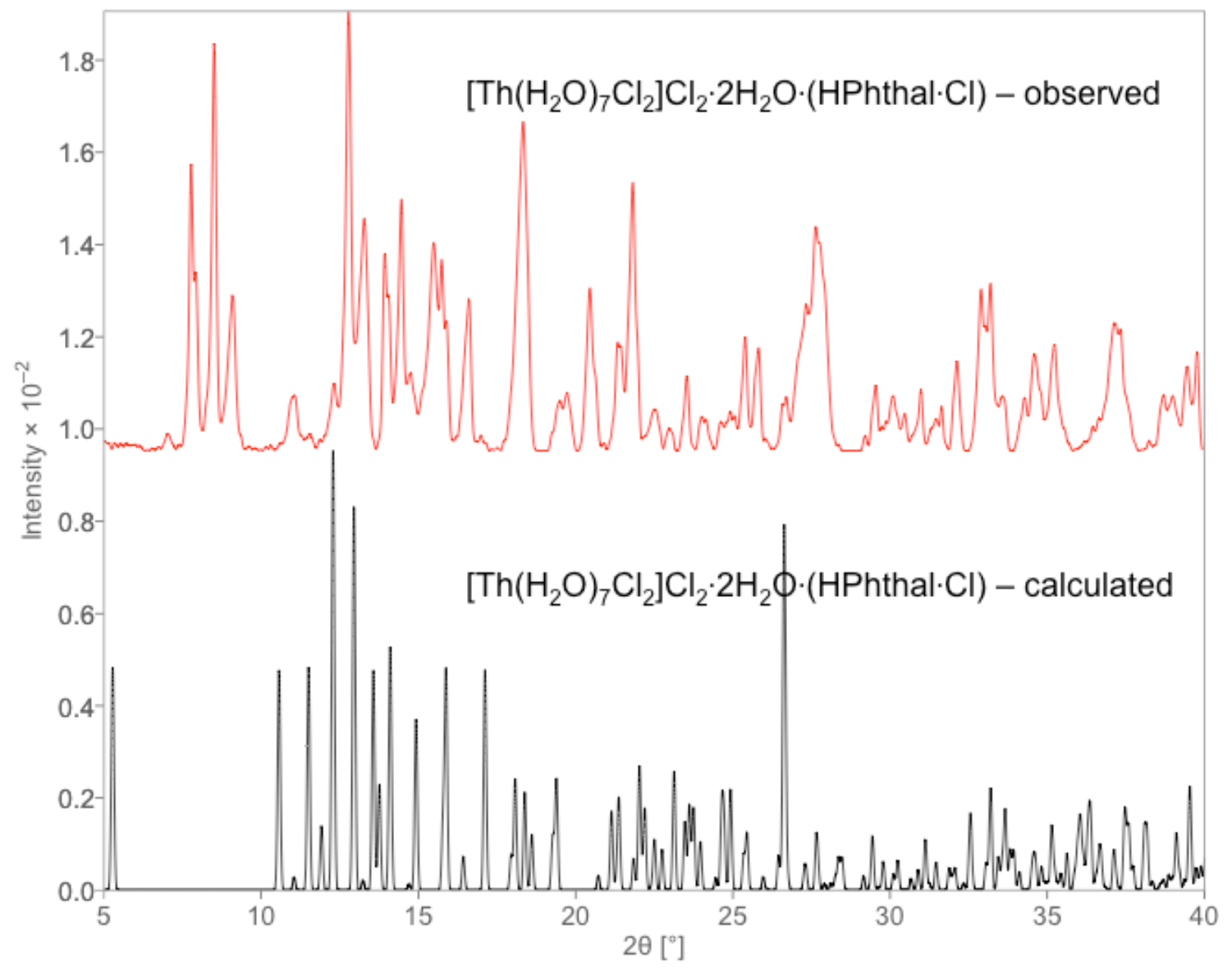

Figure S33. Powder X-ray diffraction pattern (collected with $\mathrm{Cu} \mathrm{K \alpha}$ radiation) observed for Th4 (red) overlaid with the pattern calculated from the single crystal structure at $100 \mathrm{~K}$ (black). 


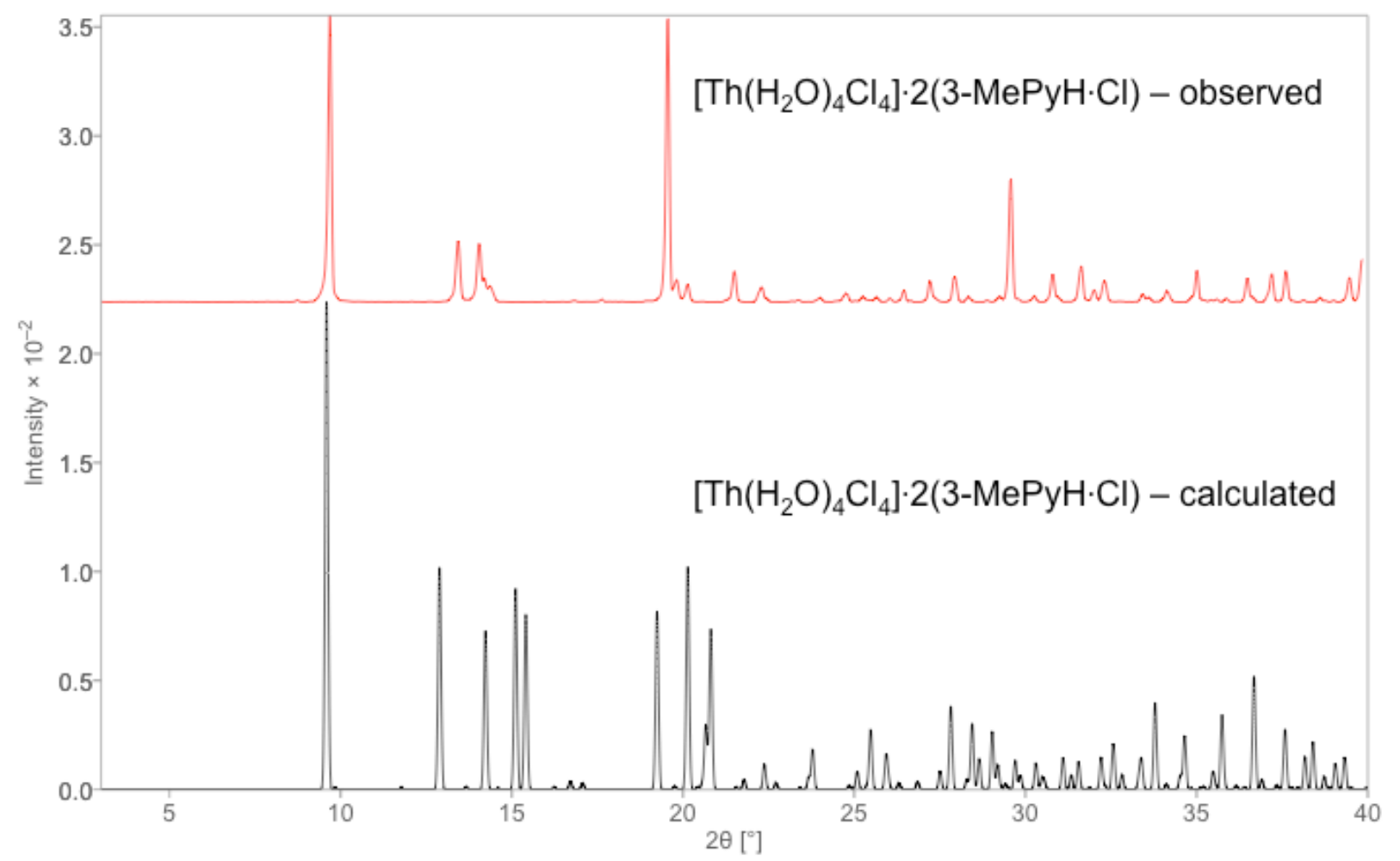

Figure S34. Powder X-ray diffraction pattern (collected with $\mathrm{Cu} \mathrm{K} \alpha$ radiation) observed for Th5 (red) overlaid with the pattern calculated from the single crystal structure at $100 \mathrm{~K}$ (black). 


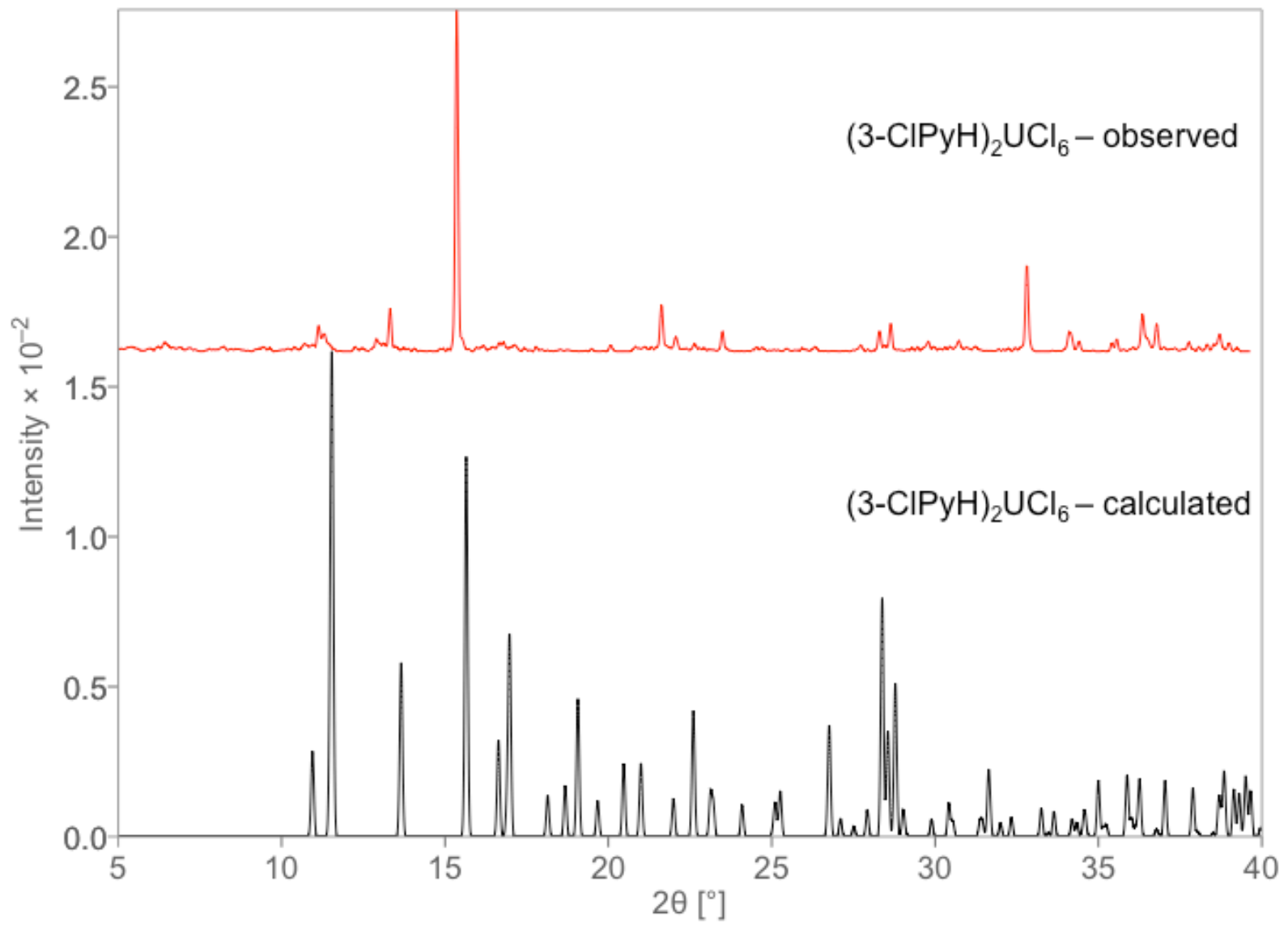

Figure S35. Powder X-ray diffraction pattern (collected with $\mathrm{Cu} \mathrm{K} \alpha$ radiation) observed for U-6 (red) overlaid with the pattern calculated from the single crystal structure at $100 \mathrm{~K}$ (black). 


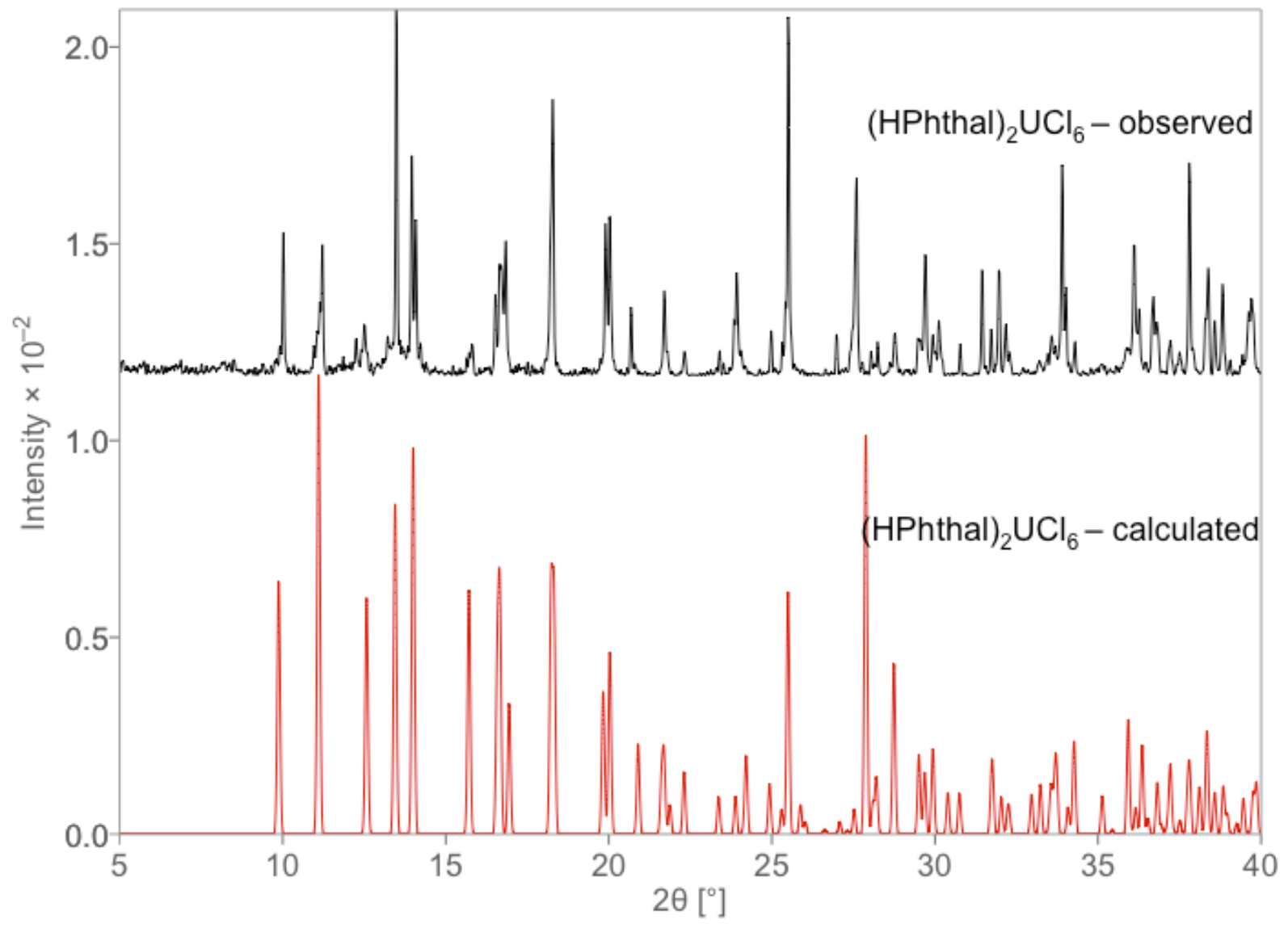

Figure S36. Powder X-ray diffraction pattern (collected with $\mathrm{Cu} \mathrm{K} \alpha$ radiation) observed for $\mathbf{U}$ 10 (black) overlaid with the pattern calculated from the single crystal structure at $100 \mathrm{~K}$ (red). 


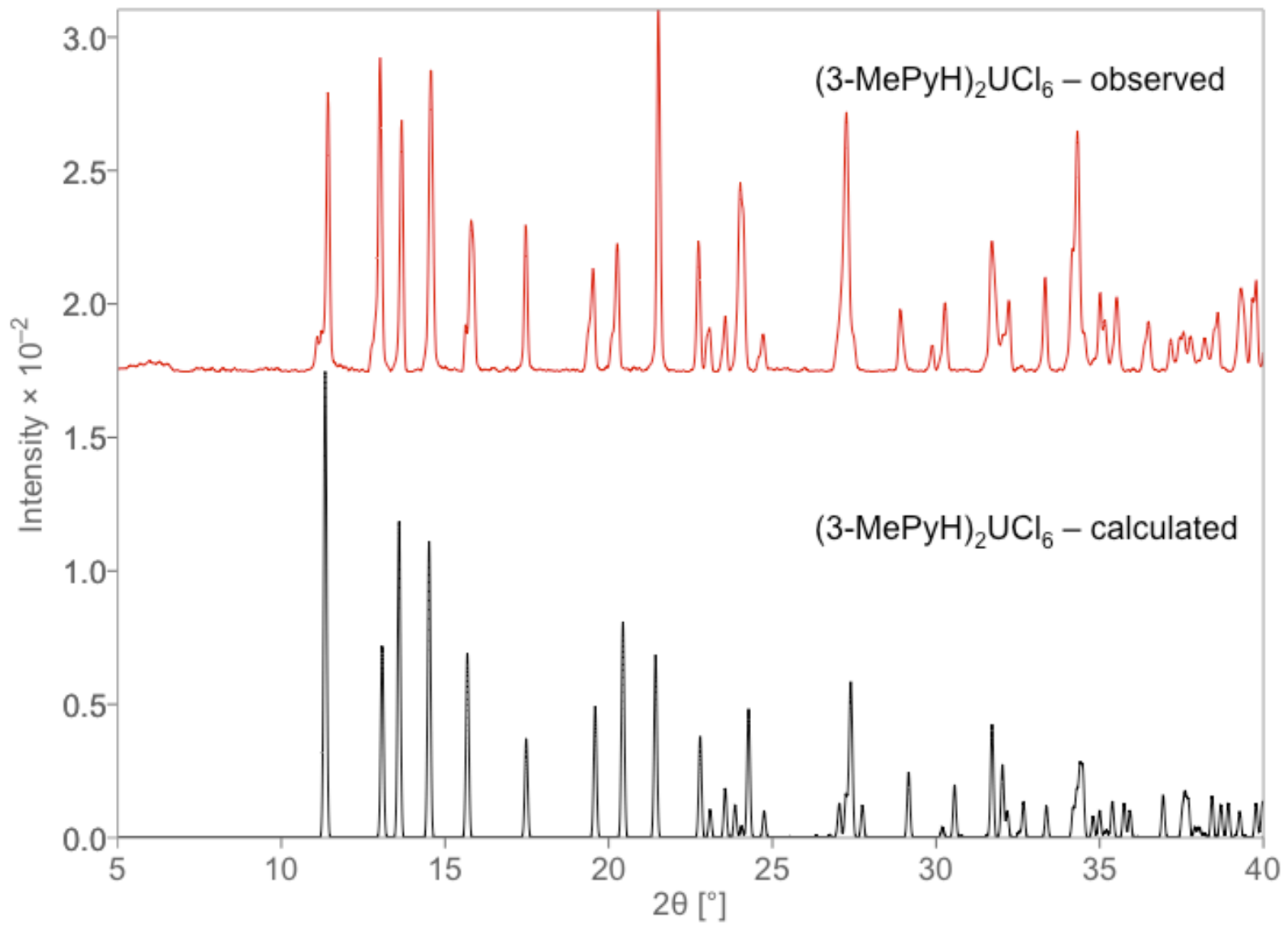

Figure S37. Powder X-ray diffraction pattern (collected with $\mathrm{Cu} \mathrm{Ka}$ radiation) observed for $\mathbf{U}$ 11 (red) overlaid with the pattern calculated from the single crystal structure at $100 \mathrm{~K}$ (black).

\section{Pu Raman spectroscopy sample holders}

(a)

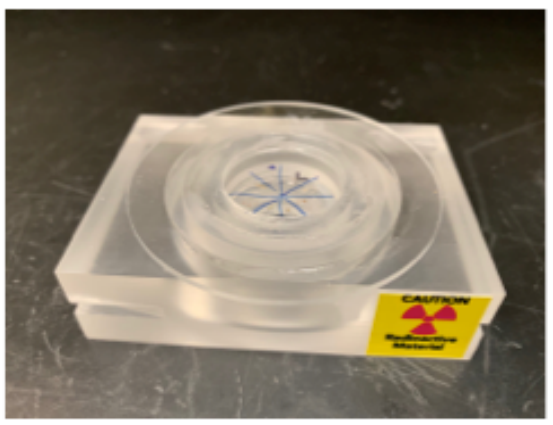

(b)

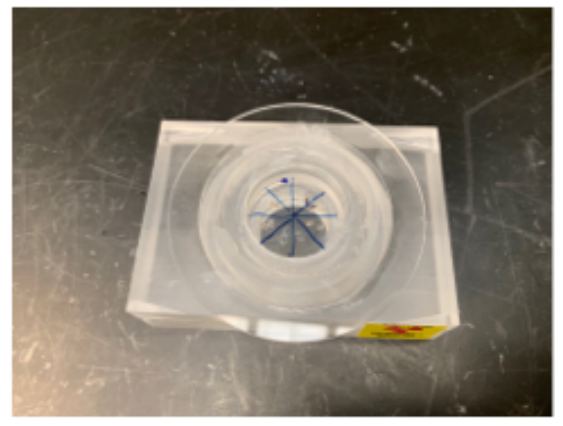

Photo S2. Plexiglass sample holders with quartz viewing window designed to contain $\mathrm{Pu}$ samples during Raman data collection. 


\section{Raman and IR characterization}

Table S2. Assignment of characteristic IR and Raman bands in Th-2. ${ }^{1-2}$

\begin{tabular}{|c|c|c|}
\hline $\operatorname{IR}\left(\mathrm{cm}^{-1}\right)$ & $\operatorname{Raman}\left(\mathrm{cm}^{-1}\right)$ & Assignment \\
\hline $3421 \mathrm{~s}, \mathrm{~b}$ & & $v(\mathrm{OH})$ \\
\hline $3294 \mathrm{~m}$ & $3304 \mathrm{w}$ & $v(\mathrm{NH})$ \\
\hline $3175 \mathrm{~m}$ & $3171 \mathrm{w}, \mathrm{b}$ & $v(\mathrm{NH})$ \\
\hline \multirow[t]{4}{*}{$3090 \mathrm{~s}$} & $3083 \mathrm{w}$ & $v(\mathrm{CH})$ \\
\hline & $3063 \mathrm{w}$ & $v(\mathrm{CH})$ \\
\hline & $3049 \mathrm{w}$ & $v(\mathrm{CH})$ \\
\hline & $3031 \mathrm{w}$ & $v(\mathrm{CH})$ \\
\hline $3012 \mathrm{~s}, \mathrm{~b}$ & $3007 \mathrm{w}$ & $v(\mathrm{CH})$ \\
\hline \multirow[t]{3}{*}{$2855 \mathrm{~m}$} & $2926 \mathrm{w}, \mathrm{b}, \mathrm{sh}$ & $v(\mathrm{CH})$ \\
\hline & $1654 \mathrm{~m}, \mathrm{~s}$ & $v$ (ring) \\
\hline & $1642 \mathrm{vs}$ & $\mathrm{H}_{2} \mathrm{O}$ bend or $v(\mathrm{C}=\mathrm{N})$ \\
\hline $1620 \mathrm{~s}$ & $1621 \mathrm{~m}, \mathrm{~b}, \mathrm{sh}$ & $\mathrm{H}_{2} \mathrm{O}$ bend or $v(\mathrm{C}=\mathrm{N})$ \\
\hline $1584 \mathrm{~s}$ & 1524 vs & $v($ ring $)$ \\
\hline $1502 \mathrm{w}$ & & $\delta($ aryl-H bend $)$ \\
\hline $1481 \mathrm{~s}$ & & $\mathrm{~N}-\mathrm{H}$ bend \\
\hline $1458 \mathrm{~s}$ & & $\delta(\mathrm{OH}$ bend $)$ \\
\hline \multicolumn{3}{|l|}{$1326 \mathrm{w}, \mathrm{b}$} \\
\hline $1296 \mathrm{w}$ & $\begin{array}{c}1287 \mathrm{vs} \\
1247 \mathrm{~m}, \mathrm{~s}\end{array}$ & $v($ ring $)+\delta(\mathrm{CH})$ \\
\hline $1223 \mathrm{~s}$ & $1223 \mathrm{~m}$ & \\
\hline $1193 \mathrm{~s}$ & $1194 \mathrm{w}, \mathrm{b}$ & $v(\operatorname{ring})+\gamma(\mathrm{CH})$ \\
\hline \multicolumn{3}{|l|}{$1120 \mathrm{w}$} \\
\hline $1096 \mathrm{~m}$ & $1072 \mathrm{~m}$ & $v($ ring $)+\delta(\mathrm{CH})$ \\
\hline \multicolumn{3}{|l|}{$1055 \mathrm{~m}$} \\
\hline $1020 \mathrm{~m}$ & $1023 \mathrm{~s}$ & $v($ ring $)+\delta(\mathrm{CH})$ \\
\hline $1003 \mathrm{w}$ & $1012 \mathrm{vs}$ & $v_{\mathrm{s}}($ ring $)$ \\
\hline $949 \mathrm{w}$ & $942 \mathrm{w}, \mathrm{b}$ & $v($ ring $)$ \\
\hline \multicolumn{3}{|l|}{$878 \mathrm{w}, \mathrm{b}$} \\
\hline $841 \mathrm{~m}$ & $844 \mathrm{~m}$ & $x(\mathrm{CH})$ \\
\hline 792 vs & $780 \mathrm{~m}$ & $\delta(\operatorname{ring})+v(\operatorname{ring})$ \\
\hline $741 \mathrm{~m}$ & & $x(\mathrm{CH})$ \\
\hline \multirow{2}{*}{\multicolumn{3}{|c|}{$\begin{array}{c}712 \mathrm{~m} \\
674 \mathrm{w}, \mathrm{b}\end{array}$}} \\
\hline & & \\
\hline \multicolumn{3}{|l|}{$653 \mathrm{w}$} \\
\hline $638 \mathrm{w}$ & $637 w, b$ & $\gamma($ ring $)$ \\
\hline $612 \mathrm{w}$ & & \\
\hline $554 \mathrm{w}$ & $561 \mathrm{~m}$ & $v$ (ring) \\
\hline $476 \mathrm{w}$ & & \\
\hline $435 \mathrm{w}$ & & \\
\hline $419 w$ & & \\
\hline & $338 \mathrm{w}$ & $\delta$ (ring) \\
\hline
\end{tabular}




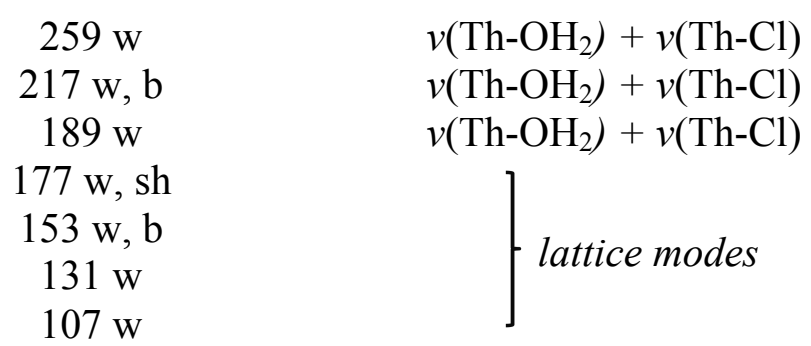

vs: very strong, s: strong, m: medium, w: weak, sh: shoulder, b:

broad; $\delta$ : in-plane deformation, $\gamma$ : out-of-plane deformation.

Table S3. Tentative IR band assignments for various Th and U compounds. ${ }^{2-5}$

\begin{tabular}{|c|c|c|c|c|}
\hline Compound & $\begin{array}{l}\text { An-Cl/An- } \\
\mathrm{O}\left(\mathrm{H}_{2}\right)\left(\mathrm{cm}^{-1}\right)\end{array}$ & $\begin{array}{l}\text { N-H bend/O-H } \\
\text { bend }\left(\mathrm{cm}^{-1}\right)\end{array}$ & $\begin{array}{c}\text { N-H stretch } \\
\left(\mathrm{cm}^{-1}\right)\end{array}$ & $\begin{array}{c}\text { O-H } \\
\text { symmetric/asymmetric } \\
\text { stretch }\left(\mathrm{cm}^{-1}\right)^{*}\end{array}$ \\
\hline Th-1 & 469 & $\begin{array}{c}1602,1621 \\
1635\end{array}$ & 3256 & 3445 \\
\hline Th-2 & 476 & 1620 & 3294 & 3427 \\
\hline Th-3 & 458,510 & $\begin{array}{l}1605,1616, \\
1623,1635\end{array}$ & 3238 & 3405 \\
\hline Th-4 & 469,519 & 1607,1624 & 3299 & 3398 \\
\hline Th-5 & 459 & $\begin{array}{c}1612,1620 \\
1629\end{array}$ & 3219 & 3320 \\
\hline U-6 & 467 & 1619 & 3203 & $3455^{* *}$ \\
\hline U-2 & 433 & $\begin{array}{c}1614,1621 \\
1645\end{array}$ & 3227 & 3433 \\
\hline U-7 & 478 & $\begin{array}{c}1617,1624 \\
1638\end{array}$ & 3215 & $\mathrm{~N} / \mathrm{A}$ \\
\hline U-3 & 450,510 & $\begin{array}{c}1605,1622 \\
1634\end{array}$ & 3283 & 3450 \\
\hline U-9 & 451,511 & $\begin{array}{l}1605,1616, \\
1623,1635\end{array}$ & 3282 & $3470^{* *}$ \\
\hline
\end{tabular}




\begin{tabular}{|c|c|c|c|c|} 
& & & \\
U-10 & 475,522 & 1602,1616 & 3152 & $3406^{* *}$ \\
U-11 & 456,505 & 511 & 3221,3243 & N/A \\
\hline
\end{tabular}

* Center of broad band.

${ }^{* *}$ Potential water impurity.

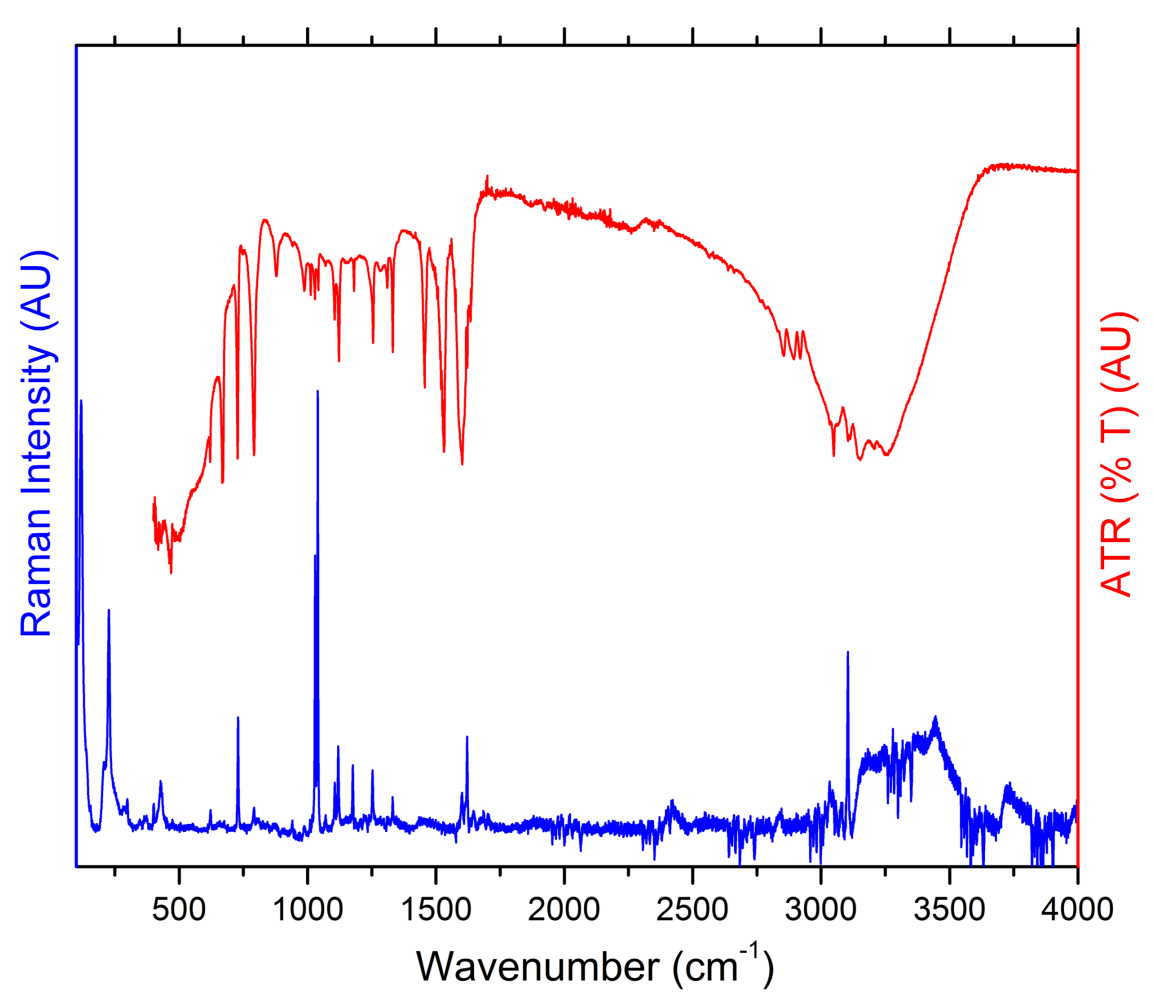

Figure S38. Infrared and Raman spectra of $\left[\mathrm{Th}\left(\mathrm{H}_{2} \mathrm{O}\right)_{6} \mathrm{Cl}_{3}\right] \mathrm{Cl} \cdot(3-\mathrm{ClPyH} \cdot \mathrm{Cl})$ (Th-1) $(\mathrm{Raman}=$ blue, IR = red). 


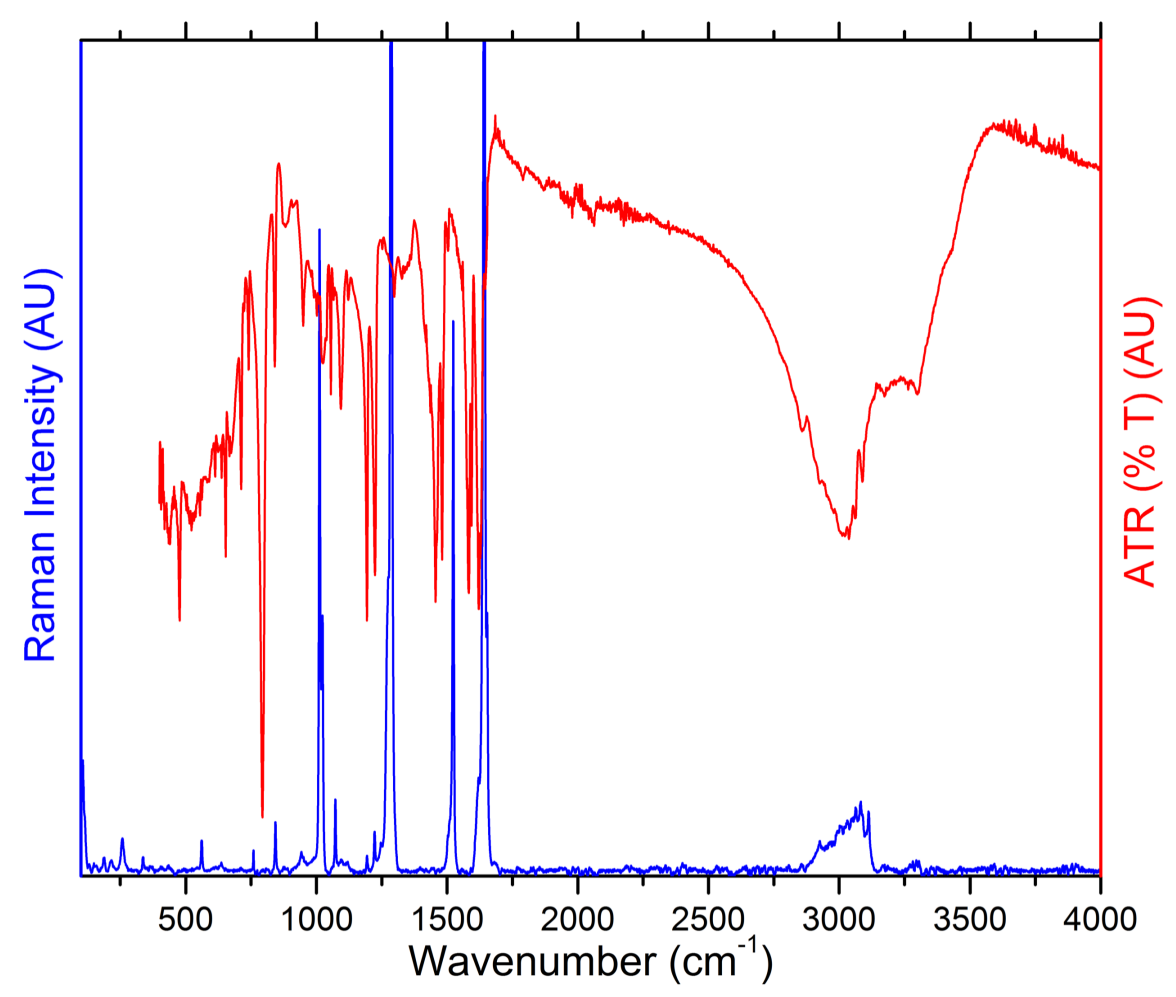

Figure S39. Infrared and Raman spectra of $\left[\mathrm{Th}\left(\mathrm{H}_{2} \mathrm{O}\right)_{5} \mathrm{Cl}_{4}\right] \cdot\left(\mathrm{H}_{2}\right.$ bipy $\left.\cdot 2 \mathrm{Cl}\right) \cdot \mathrm{H}_{2} \mathrm{O}(\mathbf{T h}-\mathbf{2})($ Raman $=$ blue, IR = red).

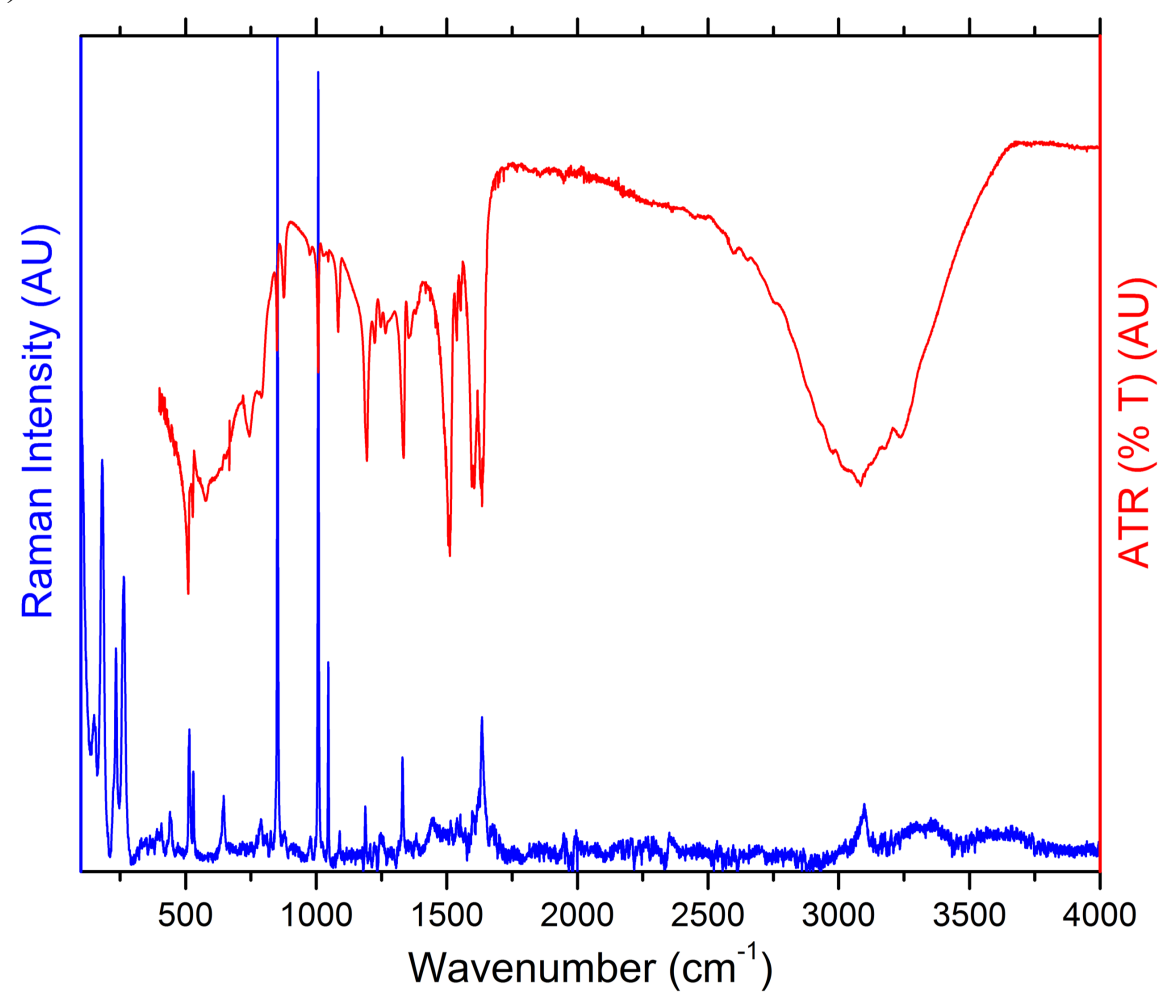

Figure S40. Infrared and Raman spectra of $\left[\mathrm{Th}\left(\mathrm{H}_{2} \mathrm{O}\right)_{4} \mathrm{Cl}_{4}\right] \cdot 2(4-\mathrm{OHPyH} \cdot \mathrm{Cl})$ (Th-3) (Raman = blue, $I R=$ red). 


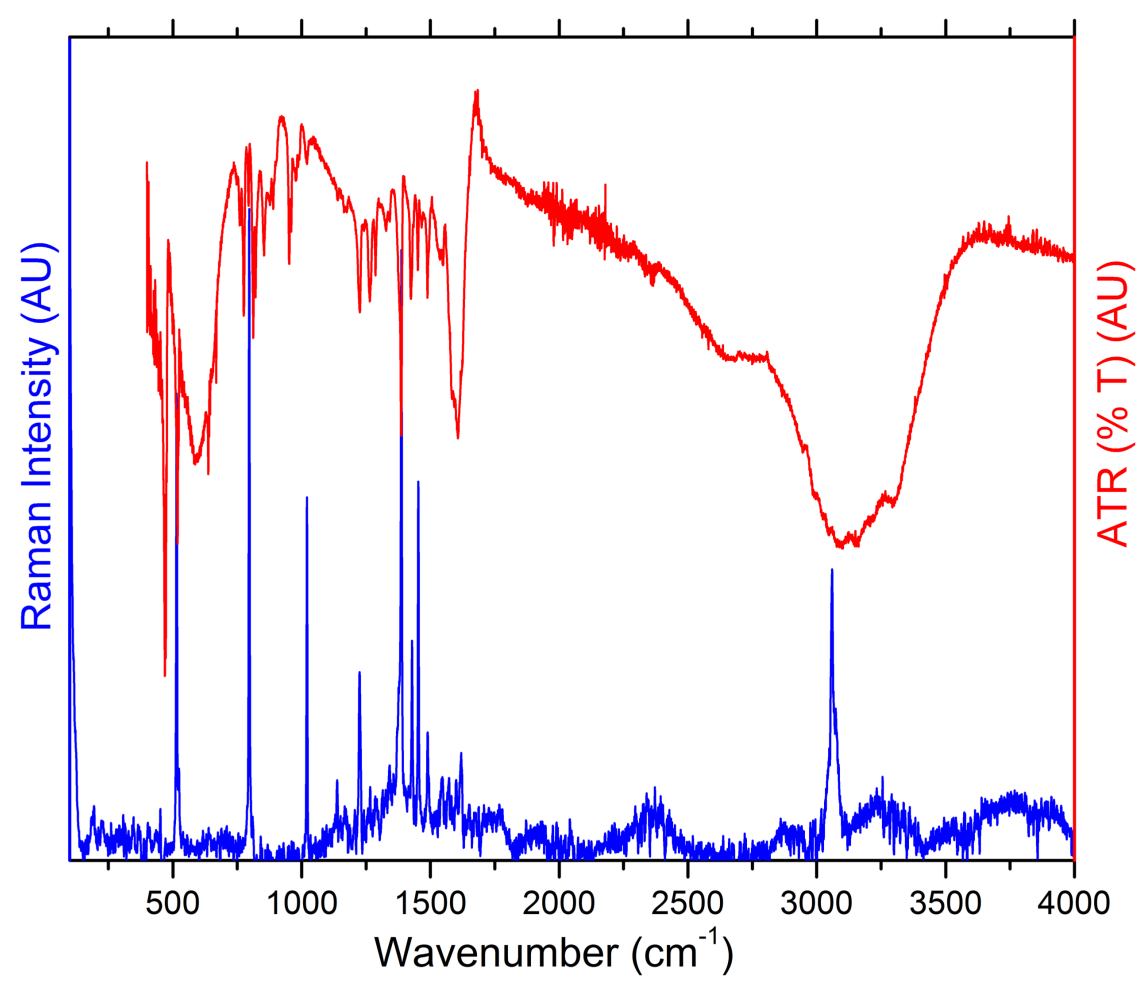

Figure S41. Infrared and Raman spectra of $\left[\mathrm{Th}\left(\mathrm{H}_{2} \mathrm{O}\right)_{7} \mathrm{Cl}_{2}\right] \mathrm{Cl}_{2} \cdot(\mathrm{HPhthal} \cdot \mathrm{Cl})$ (Th-4) $(\mathrm{Raman}=$ blue, $\mathrm{IR}=$ red).

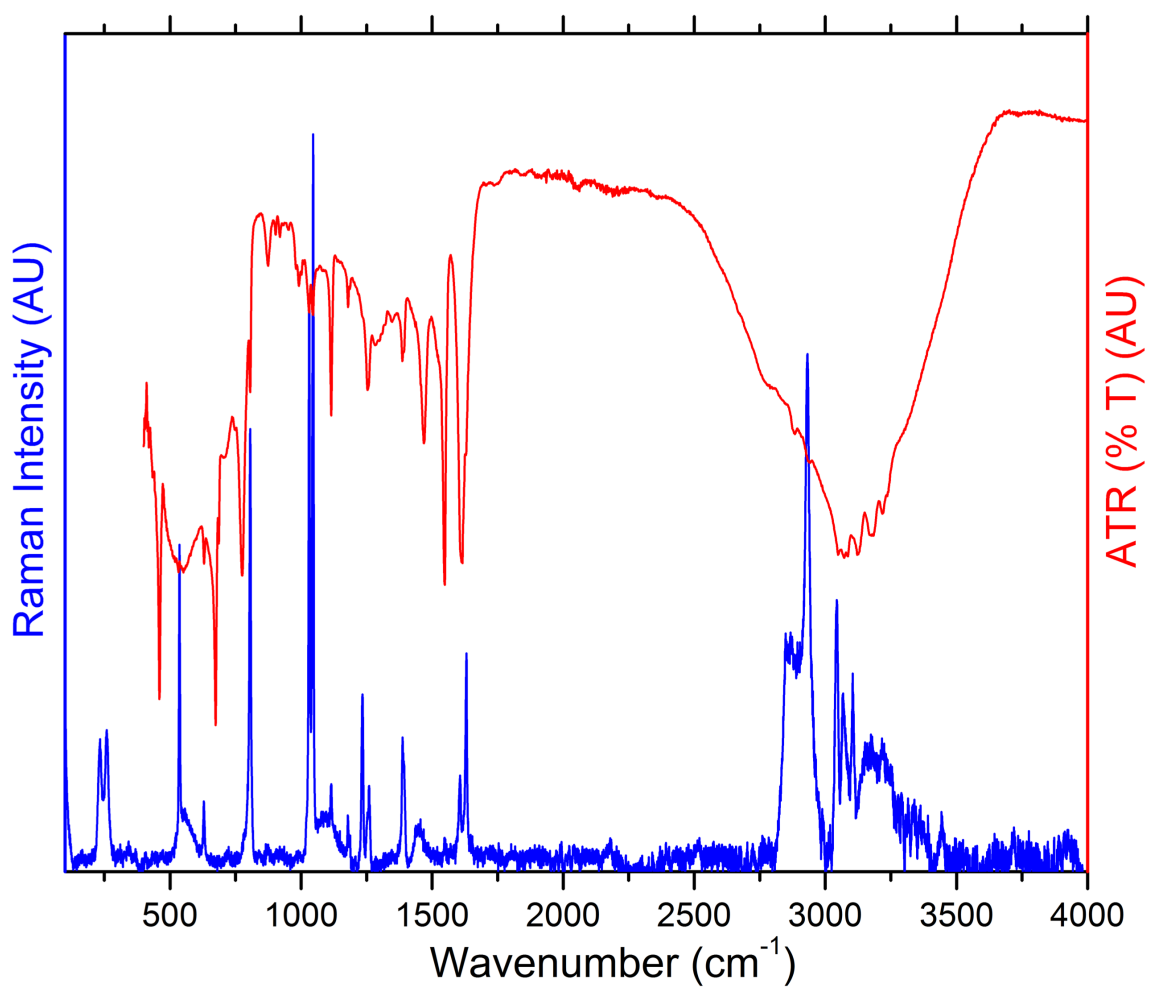

Figure S42. Infrared and Raman spectra of $\left[\mathrm{Th}\left(\mathrm{H}_{2} \mathrm{O}\right)_{4} \mathrm{Cl}_{4}\right] \cdot 2(3-\mathrm{MePy} \cdot \mathrm{Cl})(\mathbf{T h}-\mathbf{5})($ Raman = blue, $\mathrm{IR}=\mathrm{red})$. 


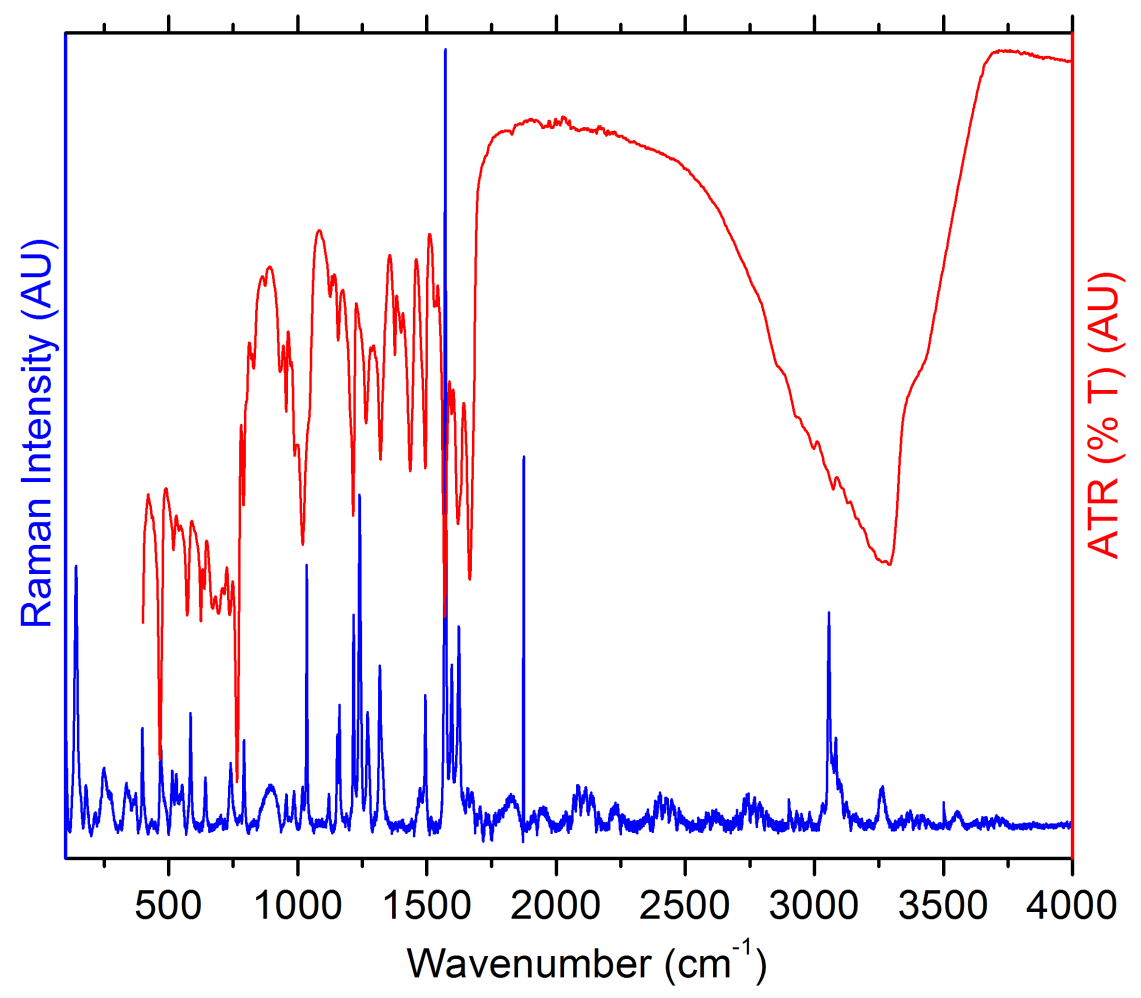

Figure S43. Infrared and Raman spectra of $(3-\mathrm{ClPyH})_{2} \mathrm{UCl}_{6}(\mathbf{U}-\mathbf{6})($ Raman $=$ blue, IR $=$ red $)$.

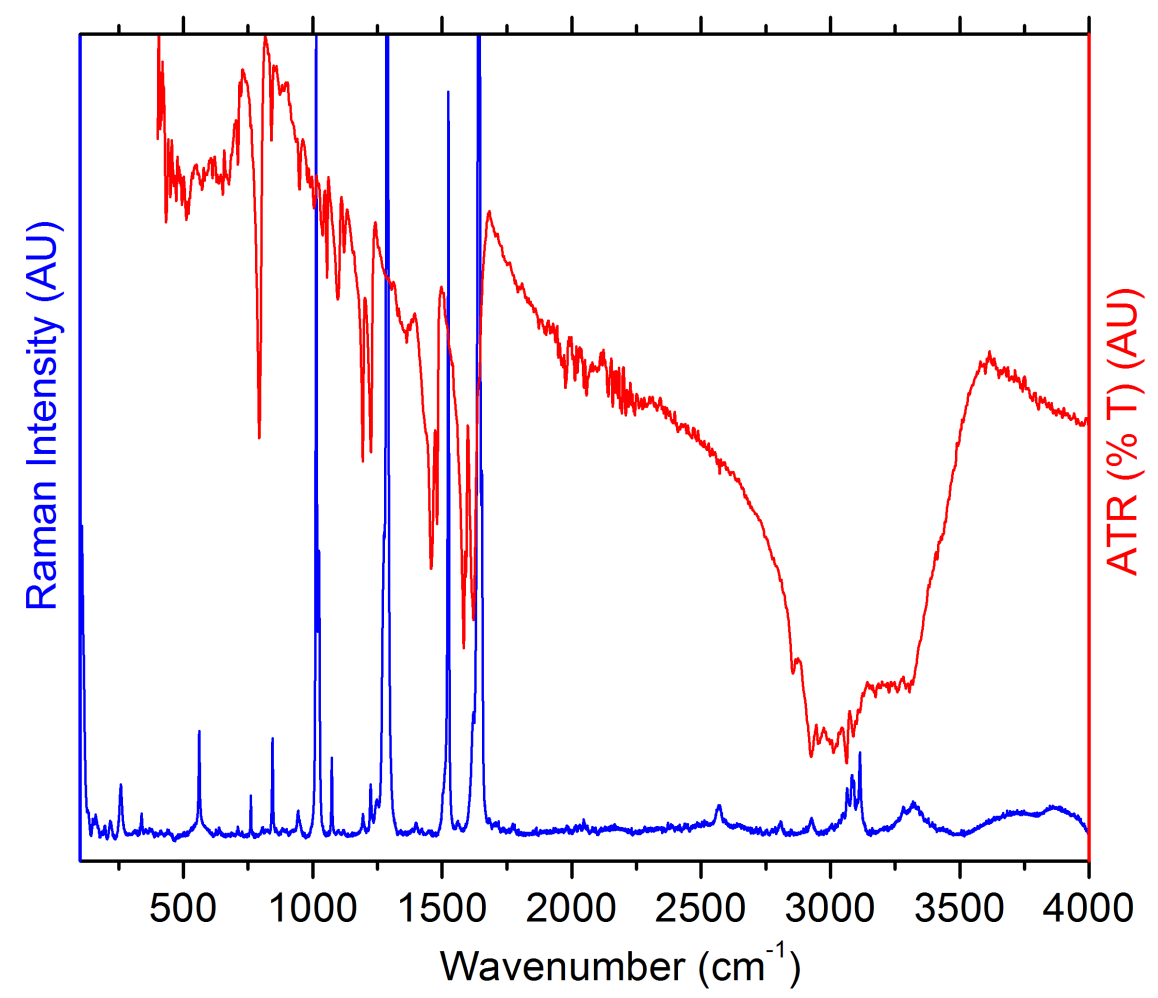

Figure S44. Infrared and Raman spectra of $\left[\mathrm{U}\left(\mathrm{H}_{2} \mathrm{O}\right)_{5} \mathrm{Cl}_{4}\right] \cdot\left(\mathrm{H}_{2}\right.$ bipy $\left.\cdot 2 \mathrm{Cl}\right) \cdot \mathrm{H}_{2} \mathrm{O}(\mathbf{U}-2)($ Raman $=$ blue, $\mathrm{IR}=$ red). 


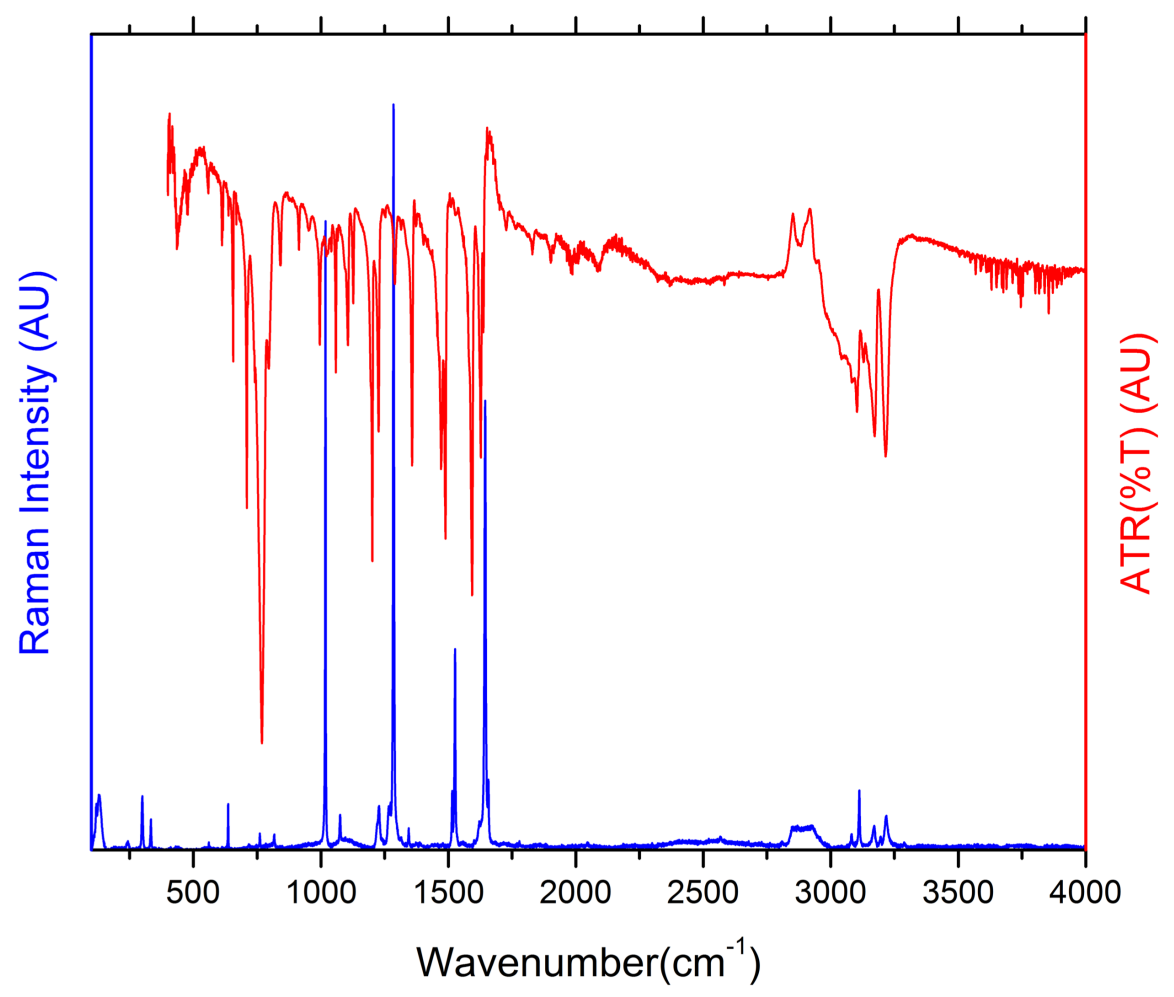

Figure S45. Infrared and Raman spectra of $\left(\mathrm{H}_{2}\right.$ bipy $) \mathrm{UCl}_{6}(\mathbf{U}-7)($ Raman $=$ blue, $\mathrm{IR}=$ red $)$.

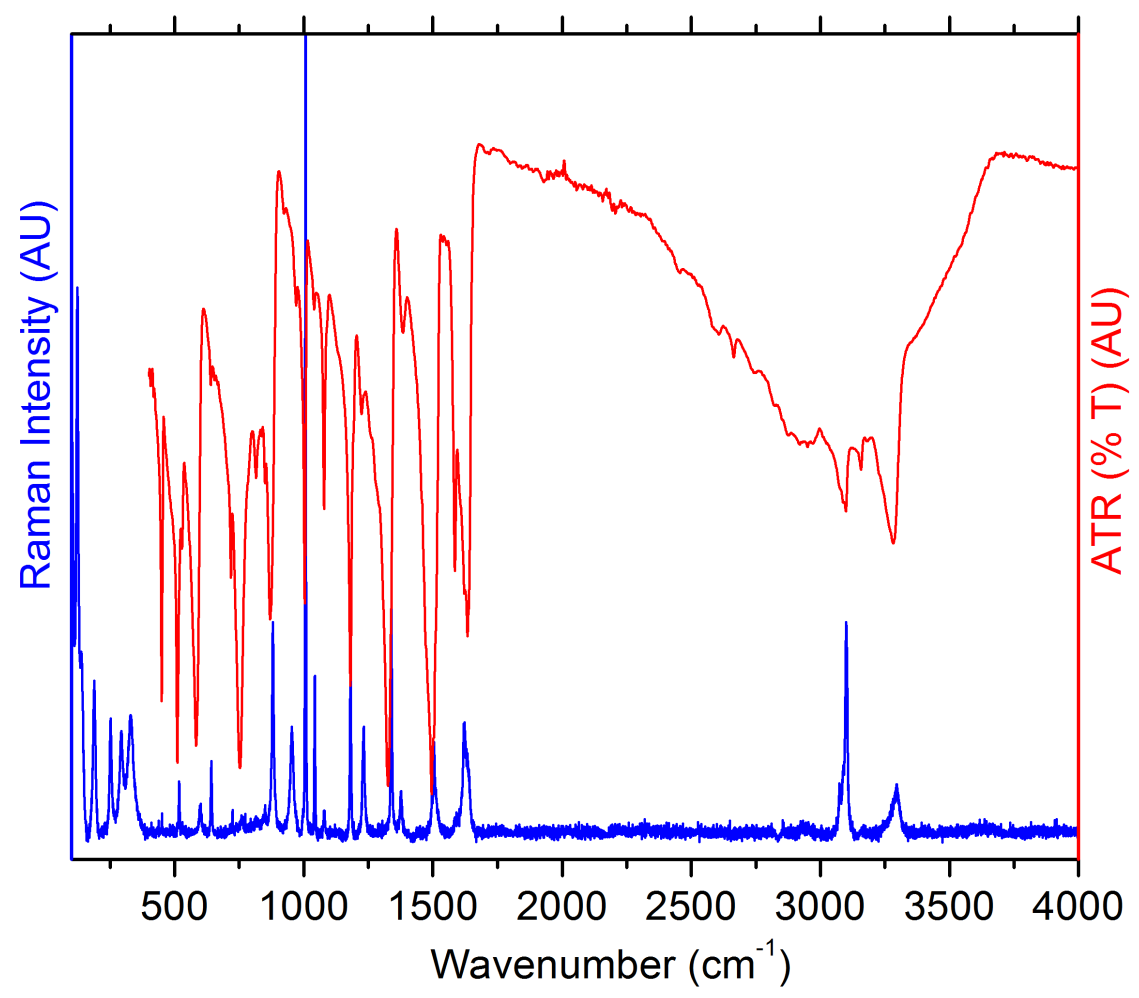

Figure S46. Infrared and Raman spectra of $\left[\mathrm{U}\left(\mathrm{H}_{2} \mathrm{O}\right)_{4} \mathrm{Cl}_{4}\right] \cdot 2(4-\mathrm{OHPyH} \cdot \mathrm{Cl})(\mathbf{U}-3)($ Raman $=$ blue, $\mathrm{IR}=\mathrm{red})$. 


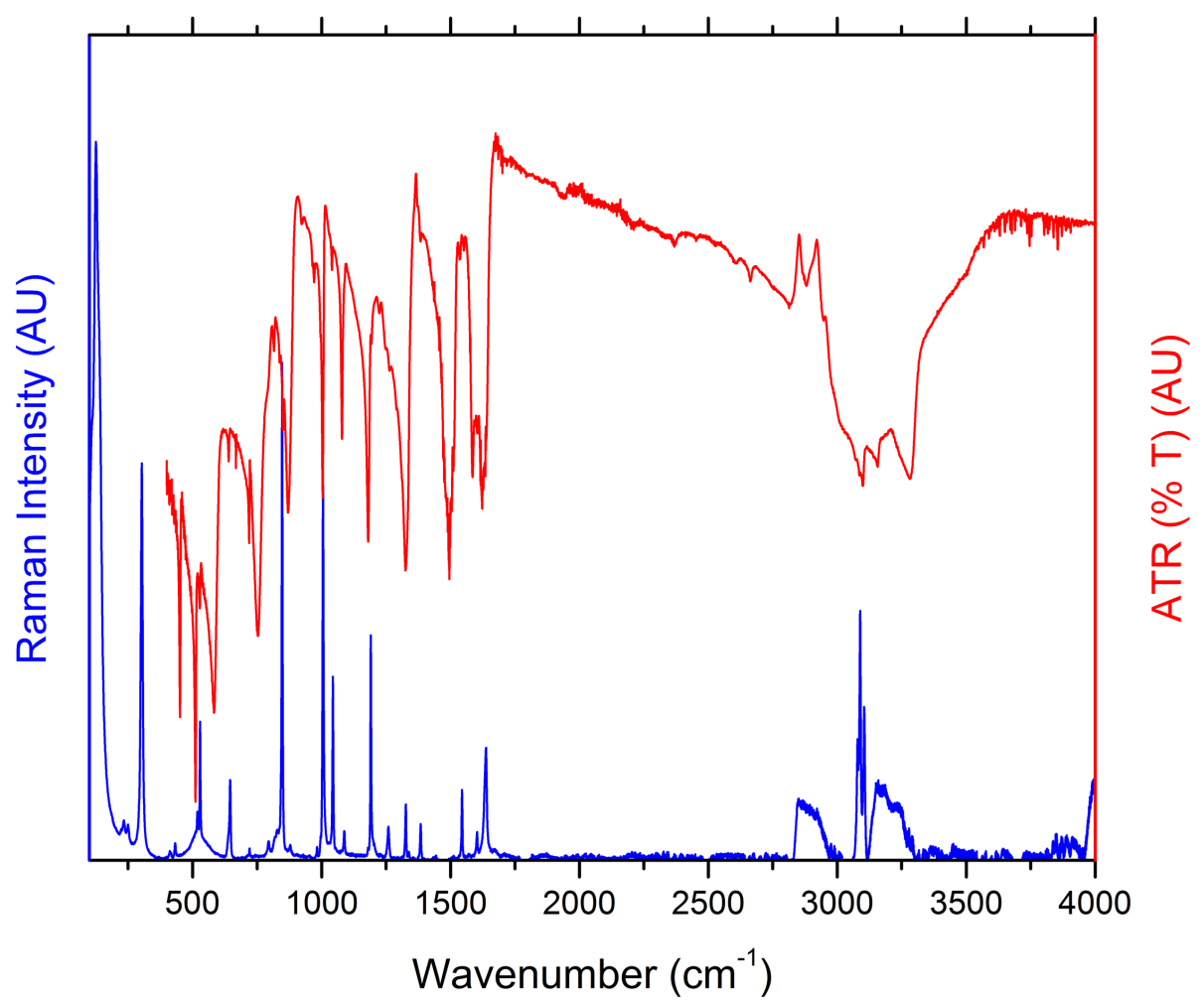

Figure S47. Infrared and Raman spectra of $(4-\mathrm{OHPyH})_{2} \mathrm{UCl}_{6}(\mathbf{U}-9)($ Raman $=$ blue, $\mathrm{IR}=$ red $)$.

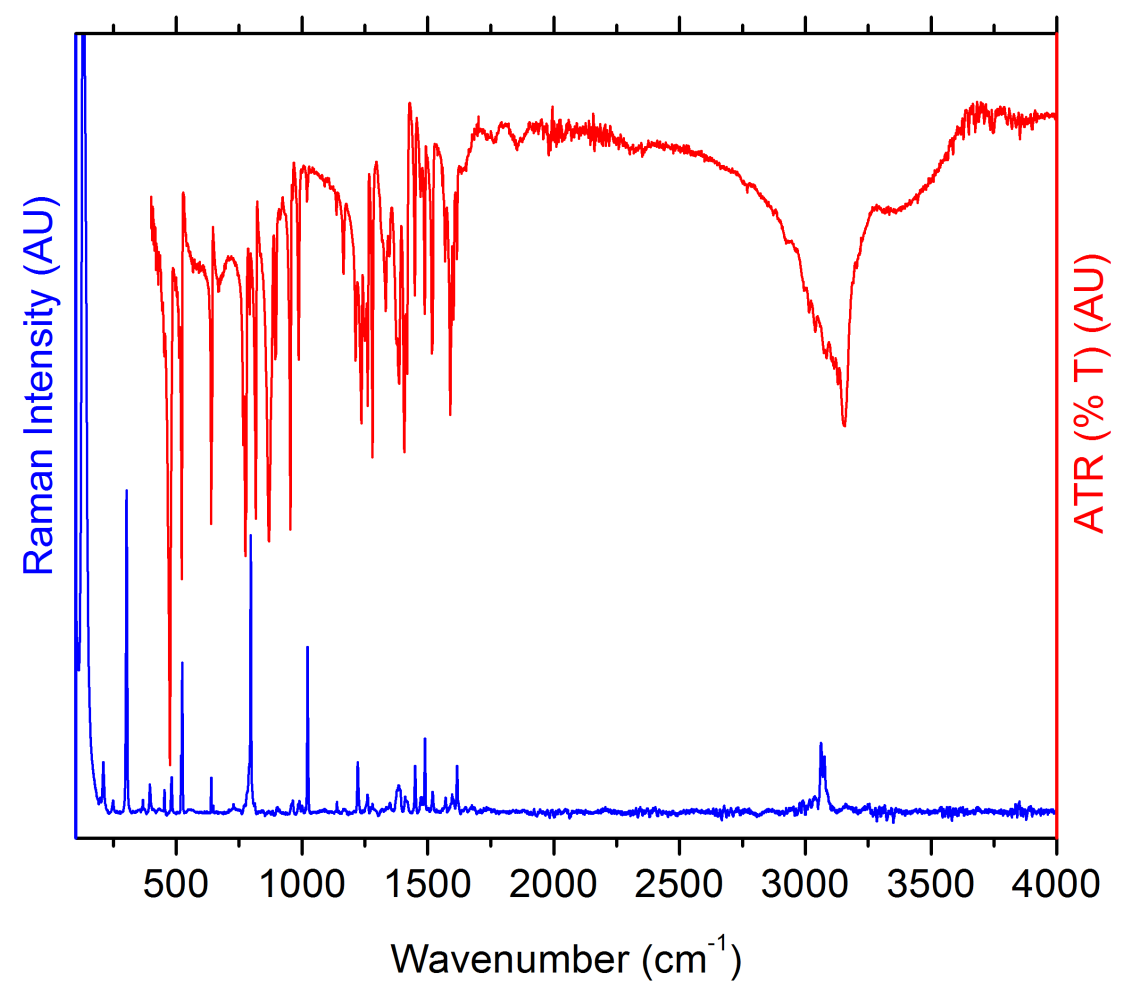

Figure S48. Infrared and Raman spectra of $\left(\mathrm{HPhthal}_{2} \mathrm{UCl}_{6}(\mathrm{U}-10)(\right.$ Raman $=$ blue, $\mathrm{IR}=$ red $)$. 


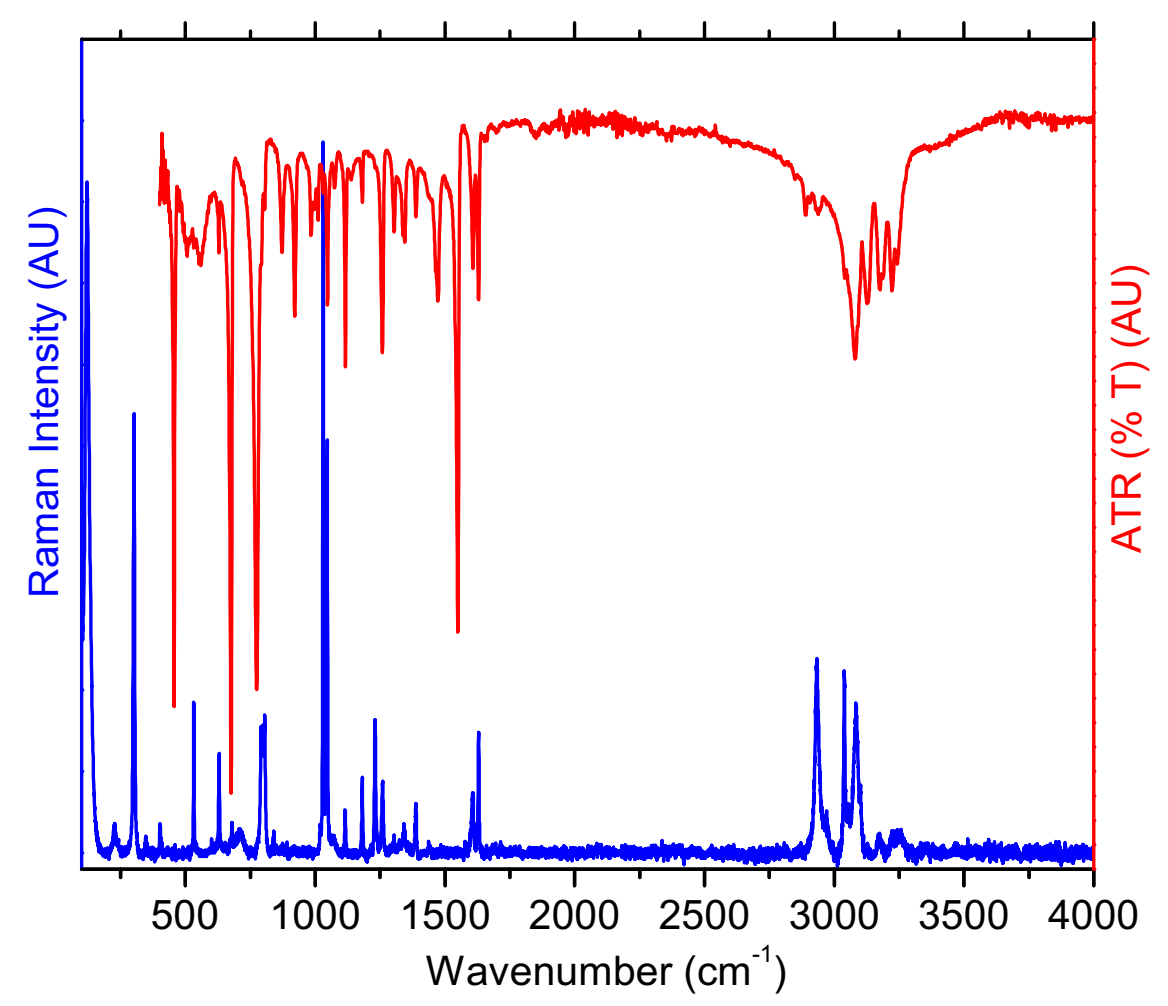

Figure S49. Infrared and Raman spectra of $(3-\mathrm{MePyH})_{2} \mathrm{UCl}_{6}(\mathbf{U}-11)($ Raman $=$ blue, IR $=$ red $)$.

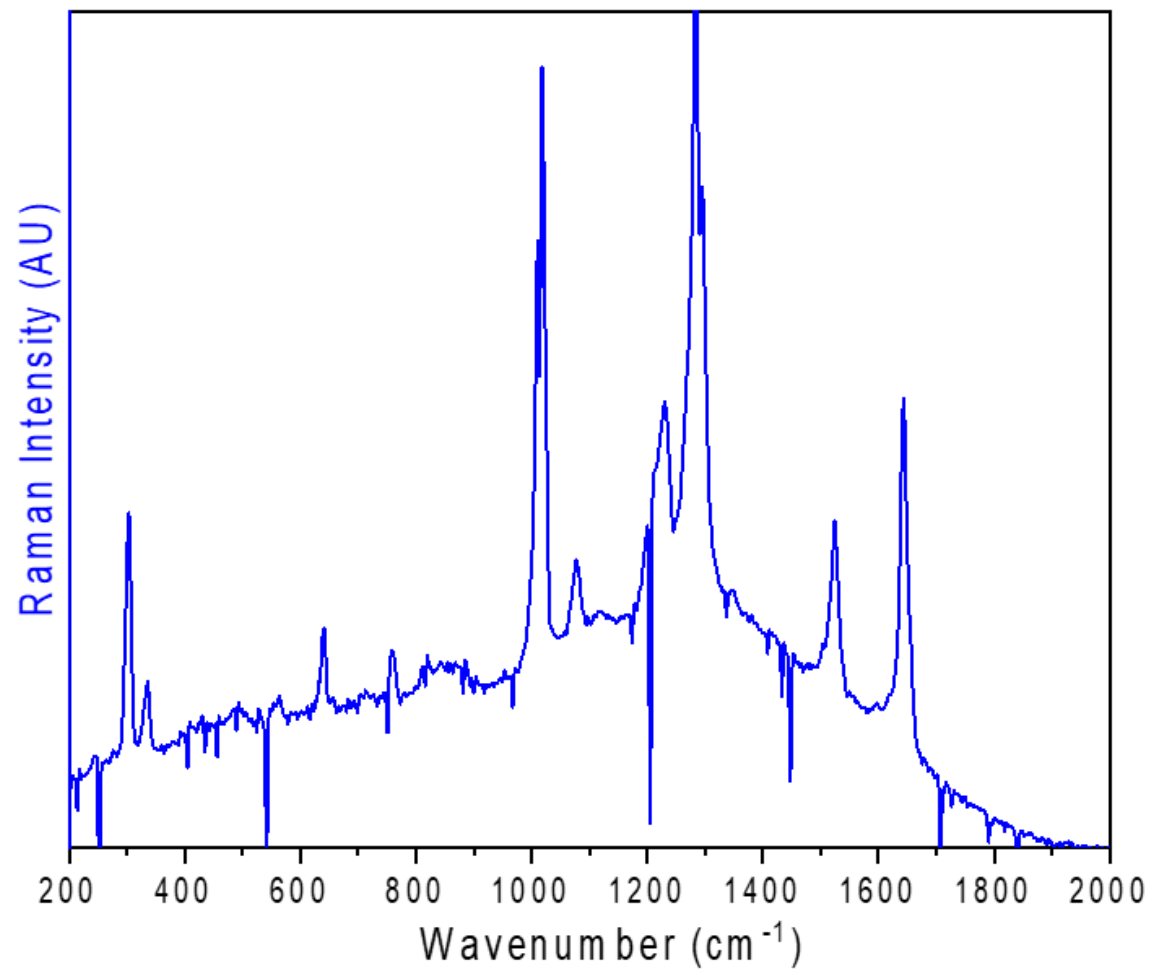

Figure S50. Raman spectrum of $\left(\mathrm{H}_{2}\right.$ bipy $) \mathrm{PuCl}_{6}$ (Pu-7). 


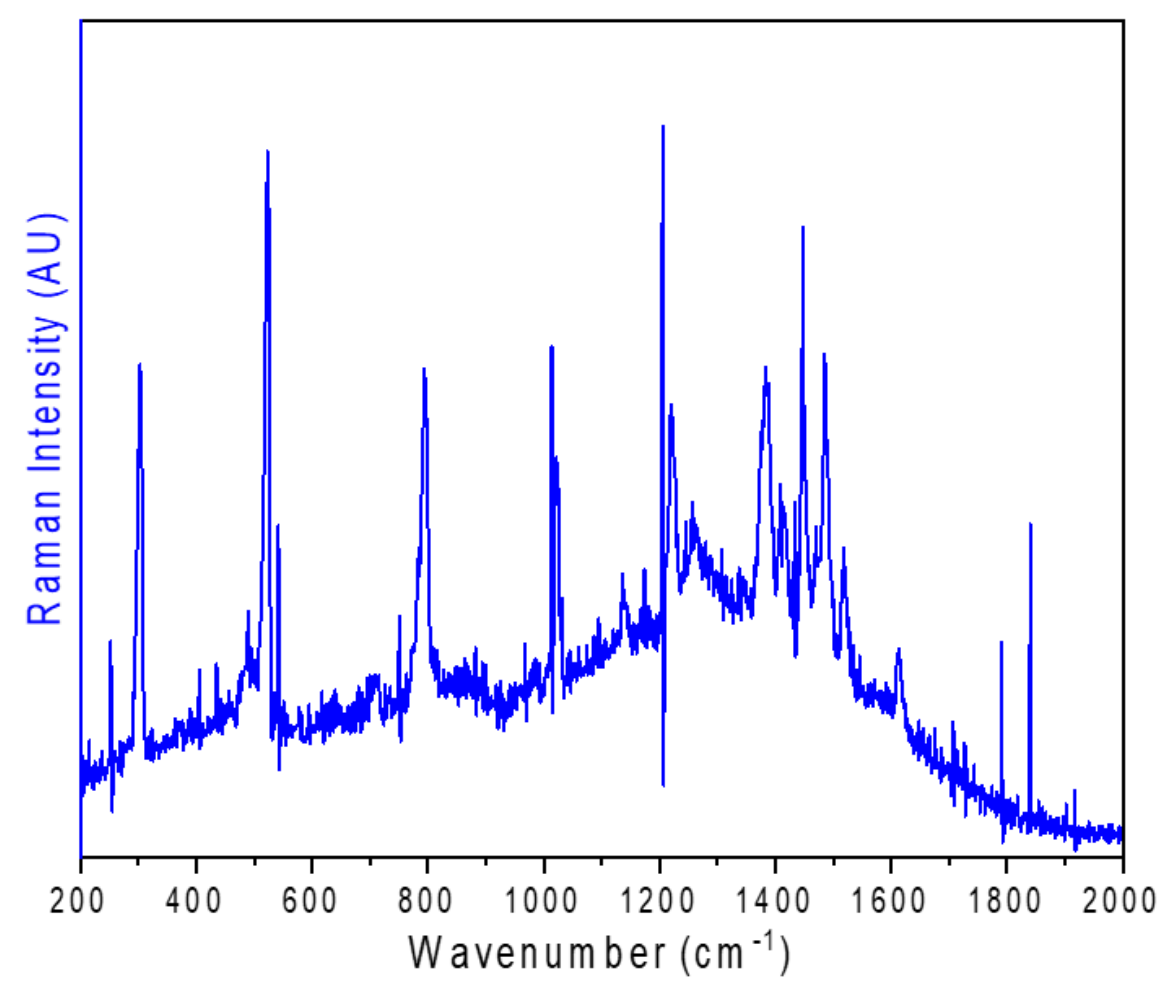

Figure S51. Raman spectrum of (HPhthal $)_{2} \mathrm{PuCl}_{6}(\mathbf{P u}-\mathbf{1 0})$.

\section{Hydrogen bonding and pi-pi stacking interactions}

$\mathrm{C}_{\mathrm{g} 1}=$ Centroid formed from ring containing atoms $\mathrm{N}_{1}, \mathrm{C}_{1}, \mathrm{C}_{2}, \mathrm{C}_{3}, \mathrm{C}_{4}, \mathrm{C}_{5}$.

$\mathrm{C}_{\mathrm{g} 2}=$ Centroid formed from ring containing atoms $\mathrm{N}_{2}, \mathrm{C}_{6} \mathrm{C}_{7}, \mathrm{C}_{8}, \mathrm{C}_{9}, \mathrm{C}_{10}$.

$\mathrm{C}_{\mathrm{g} 3}=$ Centroid formed from ring containing atoms $\mathrm{N}_{3}, \mathrm{C}_{11}, \mathrm{C}_{12}, \mathrm{C}_{13}, \mathrm{C}_{14}, \mathrm{C}_{15}$.

$\beta=$ The angle formed between $C_{g}$ and the plane normal to $C_{g}$.

$\mathrm{C}_{\mathrm{g}}-\mathrm{C}_{\mathrm{g}}=$ Distance between ring centroids.

Th compounds

Table S4. Representative hydrogen bonding distances and angles in $\left[\mathrm{Th}\left(\mathrm{H}_{2} \mathrm{O}\right)_{6} \mathrm{Cl}_{3}\right] \mathrm{Cl} \cdot(3-$ $\mathrm{ClPyH} \cdot \mathrm{Cl})$ (Th-1).

\begin{tabular}{|c|c|c|}
\hline Interaction & $\begin{array}{c}\text { Distance }(\AA) \text { donor- } \\
\text { acceptor }\end{array}$ & $\begin{array}{c}\text { Angle }\left(^{\circ}\right) \\
\angle \mathrm{D}-\mathrm{H}---\mathrm{A}\end{array}$ \\
\hline $\mathrm{N}(1) \mathrm{H}---\mathrm{Cl}(5)$ & $3.172(7)$ & $159(7)$ \\
\hline $\mathrm{O}(1) \mathrm{H}---\mathrm{Cl}(5)$ & $3.065(5)$ & $167(5)$ \\
\hline $\mathrm{O}(1) \mathrm{H}---\mathrm{Cl}(4)$ & $3.099(5)$ & $157(7)$ \\
\hline $\mathrm{O}(2) \mathrm{H}---\mathrm{Cl}(5)$ & $3.118(5)$ & $165(5)$ \\
\hline $\mathrm{O}(3) \mathrm{H}---\mathrm{Cl}(5)$ & $3.147(5)$ & $153(6)$ \\
\hline $\mathrm{O}(3) \mathrm{H}---\mathrm{Cl}(4)$ & $3.165(5)$ & $163(6)$ \\
\hline $\mathrm{O}(4) \mathrm{H}---\mathrm{Cl}(4)$ & $3.184(5)$ & $148(5)$ \\
\hline $\mathrm{O}(5) \mathrm{H}---\mathrm{Cl}(4)$ & $3.212(5)$ & $160(5)$ \\
\hline
\end{tabular}




\begin{tabular}{|c|c|c|}
\hline $\mathrm{O}(6) \mathrm{H}---\mathrm{Cl}(5)$ & $3.120(5)$ & $167(5)$ \\
\hline $\mathrm{O}(6) \mathrm{H}---\mathrm{Cl}(1)$ & $3.172(7)$ & $171(5)$ \\
\hline
\end{tabular}

Table S5. Representative hydrogen bonding distances, angles, and pi-pi stacking interactions in $\left[\mathrm{Th}\left(\mathrm{H}_{2} \mathrm{O}\right)_{5} \mathrm{Cl}_{4}\right] \cdot\left(\mathrm{H}_{2}\right.$ bipy $\left.\cdot 2 \mathrm{Cl}\right) \cdot \mathrm{H}_{2} \mathrm{O}(\mathbf{T h}-\mathbf{2})$.

\begin{tabular}{|c|c|c|c|c|}
\hline Interaction & $\begin{array}{c}\text { Distance }(\AA) \\
\text { donor-acceptor }\end{array}$ & $\begin{array}{c}\text { Angle }\left(^{\circ}\right) \\
\angle \mathrm{D}-\mathrm{H}---\mathrm{A}\end{array}$ & $\mathrm{C}_{\mathrm{g}}---\mathrm{C}_{\mathrm{g}}(\AA)$ & $\beta\left(^{\circ}\right)$ \\
\hline $\mathrm{N}(1) \mathrm{H}---\mathrm{Cl}(3)$ & $3.225(3)$ & $133.4(6)$ & - & - \\
\hline $\mathrm{N}(2) \mathrm{H}---\mathrm{Cl}(3)$ & $2.536(3)$ & $132.9(3)$ & - & - \\
\hline $\mathrm{O}(1) \mathrm{H}---\mathrm{Cl}(2)$ & $3.255(3)$ & $155(3)$ & - & - \\
\hline $\mathrm{O}(2) \mathrm{H}---\mathrm{Cl}(1)$ & $3.093(2)$ & $163(3)$ & - & - \\
\hline $\mathrm{O}(2) \mathrm{H}---\mathrm{Cl}(3)$ & $3.068(2)$ & $165(4)$ & - & - \\
\hline $\mathrm{O}(3) \mathrm{H}---\mathrm{Cl}(2)$ & $3.171(2)$ & $156(2)$ & - & - \\
\hline $\mathrm{O}(5) \mathrm{H}---\mathrm{Cl}(3)$ & $3.225(3)$ & $133.4(6)$ & - & - \\
\hline $\mathrm{C}_{\mathrm{g} 1---\mathrm{C}_{\mathrm{g} 2}}$ & - & - & $3.9183(18)$ & 24.1 \\
\hline
\end{tabular}

Table S6. Representative hydrogen bonding distances, angles, and pi-pi stacking interactions in $\left[\mathrm{Th}\left(\mathrm{H}_{2} \mathrm{O}\right)_{4} \mathrm{Cl}_{4}\right] \cdot 2(4-\mathrm{OHPyH} \cdot \mathrm{Cl})$ (Th-3).

\begin{tabular}{|c|c|c|c|c|}
\hline Interaction & $\begin{array}{c}\text { Distance }(\AA) \\
\text { donor-acceptor }\end{array}$ & $\begin{array}{c}\text { Angle }\left(^{\circ}\right) \\
\angle \mathrm{D}-\mathrm{H}---\mathrm{A}\end{array}$ & $\mathrm{C}_{\mathrm{g}}---\mathrm{C}_{\mathrm{g}}$ & $\beta\left(^{\circ}\right)$ \\
\hline $\mathrm{N}(1) \mathrm{H}---\mathrm{Cl}(1)$ & $3.416(5)$ & 136 & - & - \\
\hline $\mathrm{N}(2) \mathrm{H}---\mathrm{Cl}(2)$ & $3.263(4)$ & 151 & - & - \\
\hline $\begin{array}{c}\text { Intra } \\
\mathrm{O}(1) \mathrm{H}---\mathrm{Cl}(1)\end{array}$ & $2.975(3)$ & $105(3)$ & - & - \\
\hline $\mathrm{O}(1) \mathrm{H}---\mathrm{Cl}(3)$ & $3.074(5)$ & $156(4)$ & - & - \\
\hline $\mathrm{O}(2) \mathrm{H}---\mathrm{Cl}(1)$ & $3.106(3)$ & $158(2)$ & - & - \\
\hline $\mathrm{O}(3) \mathrm{H}---\mathrm{Cl}(3)$ & $3.033(4)$ & $165(3)$ & - & - \\
\hline $\mathrm{O}(4) \mathrm{H}---\mathrm{Cl}(3)$ & $2.870(5)$ & 145 & - & - \\
\hline $\mathrm{C}_{\mathrm{g} 11^{--}-\mathrm{C}_{\mathrm{g} 2}}$ & - & - & $3.673(3)$ & 20.8 \\
\hline $\mathrm{C}_{\mathrm{g} 2---\mathrm{C}_{\mathrm{g} 1}}$ & - & - & $3.910(3)$ & 27.9 \\
\hline
\end{tabular}

Table S7. Representative hydrogen bonding distances, angles, and pi-pi stacking interactions in $\left.\left[\mathrm{Th}\left(\mathrm{H}_{2} \mathrm{O}\right)_{7} \mathrm{Cl}_{2}\right] \mathrm{Cl}_{2} \cdot(\mathrm{HPhthal} \cdot \mathrm{Cl}) \mathbf{( T h}-4\right)$.

\begin{tabular}{|c|c|c|c|c|}
\hline Interaction & $\begin{array}{c}\text { Distance }(\AA) \\
\text { donor-acceptor }\end{array}$ & $\begin{array}{c}\text { Angle }\left(^{\circ}\right) \\
\angle \mathrm{D}-\mathrm{H}---\mathrm{A}\end{array}$ & $\mathrm{C}_{\mathrm{g}}---\mathrm{C}_{\mathrm{g}}$ & $\beta\left(^{\mathrm{o}}\right)$ \\
\hline $\mathrm{O}(6) \mathrm{H}---\mathrm{N}(1)$ & $2.794(3)$ & $173(3)$ & - & - \\
\hline $\mathrm{O}(1) \mathrm{H}---\mathrm{Cl}(5)$ & $3.1313(18)$ & $159(3)$ & - & - \\
\hline $\mathrm{O}(1) \mathrm{H}---\mathrm{Cl}(3)$ & $3.0938(18)$ & $169(3)$ & - & - \\
\hline $\mathrm{O}(2) \mathrm{H}---\mathrm{Cl}(4)$ & $3.1646(18)$ & $146(2)$ & - & - \\
\hline $\mathrm{O}(3) \mathrm{H}---\mathrm{Cl}(3)$ & $3.0618(17)$ & $168(2)$ & - & - \\
\hline $\mathrm{O}(4) \mathrm{H}---\mathrm{Cl}(4)$ & $3.0559(18)$ & $170(3)$ & - & - \\
\hline $\mathrm{O}(5) \mathrm{H}---\mathrm{Cl}(4)$ & $3.2611(18)$ & $156(2)$ & - & - \\
\hline $\mathrm{O}(7) \mathrm{H}---\mathrm{Cl}(5)$ & $3.0240(19)$ & $173(3)$ & - & - \\
\hline
\end{tabular}




\begin{tabular}{|c|c|c|c|c|}
\hline $\mathrm{O}(7) \mathrm{H}---\mathrm{Cl}(3)$ & $3.0294(18)$ & $173(3)$ & - & - \\
\hline $\mathrm{C}_{\mathrm{g} 1}---\mathrm{C}_{\mathrm{g} 2}$ & - & - & 3.7913 & 26.7 \\
\hline
\end{tabular}

Table S8. Representative hydrogen bonding distances, angles, and pi-pi stacking interactions in $\left[\mathrm{Th}\left(\mathrm{H}_{2} \mathrm{O}\right)_{4} \mathrm{Cl}_{4}\right] \cdot 2(3-\mathrm{MePy} \cdot \mathrm{Cl})$ (Th-5).

\begin{tabular}{|c|c|c|c|c|}
\hline Interaction & $\begin{array}{c}\text { Distance }(\AA) \\
\text { donor-acceptor }\end{array}$ & $\begin{array}{c}\text { Angle }\left(^{\circ}\right) \\
\angle \mathrm{D}-\mathrm{H}---\mathrm{A}\end{array}$ & $\mathrm{C}_{\mathrm{g}---\mathrm{C}_{\mathrm{g}}}$ & $\beta\left(^{\mathrm{o}}\right)$ \\
\hline $\mathrm{O}(1) \mathrm{H}---\mathrm{Cl}(5)$ & $3.009(3)$ & $170(4)$ & - & - \\
\hline $\mathrm{O}(1) \mathrm{H}---\mathrm{Cl}(6)$ & $3.197(3)$ & $161(3)$ & - & - \\
\hline $\mathrm{O}(2) \mathrm{H}---\mathrm{Cl}(6)$ & $2.957(3)$ & $171(5)$ & - & - \\
\hline $\mathrm{O}(2) \mathrm{H}---\mathrm{Cl}(5)$ & $3.197(3)$ & $165(4)$ & - & - \\
\hline $\begin{array}{c}\text { Intra } \\
\mathrm{O}(3) \mathrm{H}---\mathrm{Cl}(4)\end{array}$ & $3.233(3)$ & $111(3)$ & - & - \\
\hline $\mathrm{O}(3) \mathrm{H}---\mathrm{Cl}(2)$ & $3.022(3)$ & $158(4)$ & - & - \\
\hline $\mathrm{O}(3) \mathrm{H}---\mathrm{Cl}(3)$ & $3.132(3)$ & $145(3)$ & - & - \\
\hline $\mathrm{O}(4) \mathrm{H}---\mathrm{Cl}(6)$ & $3.122(3)$ & $164(3)$ & - & - \\
\hline $\mathrm{O}(4) \mathrm{H}---\mathrm{Cl}(5)$ & $3.055(3)$ & $173(4)$ & - & - \\
\hline $\mathrm{C}_{\mathrm{g} 1---\mathrm{C}_{\mathrm{g} 2}}$ & - & - & $3.520(6)$ & 24.4 \\
\hline $\mathrm{C}_{\mathrm{g} 2}----\mathrm{C}_{\mathrm{g} 3}$ & - & - & $3.390(14)$ & 21.2 \\
\hline
\end{tabular}

U compounds

Table S9. Representative hydrogen bonding distances, angles, and pi-pi stacking interactions in $(3-\mathrm{ClPyH})_{2} \mathrm{UCl}_{6}(\mathbf{U}-\mathbf{6})$.

\begin{tabular}{|c|c|c|c|c|}
\hline Interaction & $\begin{array}{c}\text { Distance }(\AA) \\
\text { donor-acceptor }\end{array}$ & $\begin{array}{c}\text { Angle }\left(^{\circ}\right) \\
\angle \mathrm{D}-\mathrm{H}---\mathrm{A}\end{array}$ & $\mathrm{C}_{\mathrm{g} 1}---\mathrm{C}_{\mathrm{g} 1}$ & $\beta\left(^{\circ}\right)$ \\
\hline $\mathrm{N}(1) \mathrm{H}---\mathrm{Cl}(2)$ & $3.163(2)$ & $152(3)$ & - & - \\
\hline $\mathrm{C}_{\mathrm{g} 1---\mathrm{C}_{\mathrm{g} 1}}$ & - & - & $3.6281(15)$ & 19.2 \\
\hline
\end{tabular}

Table S10. Representative hydrogen bonding distances, angles, and pi-pi stacking interactions in $\left[\mathrm{U}\left(\mathrm{H}_{2} \mathrm{O}\right)_{5} \mathrm{Cl}_{4}\right] \cdot\left(\mathrm{H}_{2}\right.$ bipy $\left.\cdot 2 \mathrm{Cl}\right) \cdot \mathrm{H}_{2} \mathrm{O}(\mathbf{U}-\mathbf{2})$.

\begin{tabular}{|c|c|c|c|c|}
\hline Interaction & $\begin{array}{c}\text { Distance }(\AA) \\
\text { donor-acceptor }\end{array}$ & $\begin{array}{c}\text { Angle }\left(^{\circ}\right) \\
\angle \mathrm{D}-\mathrm{H}---\mathrm{A}\end{array}$ & $\mathrm{C}_{\mathrm{g} 1}---\mathrm{C}_{\mathrm{g} 1}$ & $\beta\left(^{\circ}\right)$ \\
\hline $\mathrm{N}(2) \mathrm{H}---\mathrm{Cl}(3)$ & $3.220(2)$ & 129 & - & - \\
\hline $\mathrm{O}(2) \mathrm{H}---\mathrm{Cl}(2)$ & $3.1741(19)$ & $154(2)$ & - & - \\
\hline $\mathrm{O}(3) \mathrm{H}---\mathrm{Cl}(2)$ & $3.277(2)$ & $150(2)$ & - & - \\
\hline intra & $3.0161(19)$ & $104(2)$ & - & - \\
\hline $\mathrm{O}(3) \mathrm{H}---\mathrm{Cl}(1)$ & $3.1159(17)$ & $169(2)$ & - & - \\
\hline $\mathrm{O}(4) \mathrm{H}---\mathrm{Cl}(1)$ & $3.0645(19)$ & $165(2)$ & - & - \\
\hline $\mathrm{O}(4)---\mathrm{Cl}(3)$ & $3.1500(19)$ & $170(3)$ & - & - \\
\hline $\mathrm{O}(5)---\mathrm{Cl}(3)$ & - & - & $3.8900(15)$ & 29.1 \\
\hline $\mathrm{C}_{\mathrm{g} 1---\mathrm{C}_{\mathrm{g} 1}}$ & & &
\end{tabular}


Table S11. Representative hydrogen bonding distances and angles in $\left(\mathrm{H}_{2}\right.$ bipy $) \mathrm{UCl}_{6}(\mathbf{U}-7)$.

\begin{tabular}{|c|c|c|}
\hline Interaction & $\begin{array}{c}\text { Distance }(\AA) \text { donor- } \\
\text { acceptor }\end{array}$ & $\begin{array}{c}\text { Angle }\left(^{\circ}\right) \\
\angle \mathrm{D}-\mathrm{H}---\mathrm{A}\end{array}$ \\
\hline $\mathrm{N}(1) \mathrm{H}---\mathrm{Cl}(1)$ & $3.2941(19)$ & $134.8(6)$ \\
\hline
\end{tabular}

Table S12. Representative hydrogen bonding distances and angles in $\left[\mathrm{U}_{(}\left(\mathrm{H}_{2} \mathrm{O}\right)_{7} \mathrm{Cl}_{2}\right] \mathrm{Cl}_{2} \cdot 2 \mathrm{H}_{2} \mathrm{O}(\mathbf{U}-$ 8).

\begin{tabular}{|c|c|c|}
\hline Interaction & $\begin{array}{c}\text { Distance }(\AA) \text { donor- } \\
\text { acceptor }\end{array}$ & $\begin{array}{c}\text { Angle }\left(^{\circ}\right) \\
\angle \mathrm{D}-\mathrm{H}---\mathrm{A}\end{array}$ \\
\hline $\mathrm{O}(1) \mathrm{H}---\mathrm{Cl}(2)$ & $3.0603(18)$ & $172(3)$ \\
\hline $\mathrm{O}(2) \mathrm{H}---\mathrm{Cl}(2)$ & $3.0912(17)$ & $175(3)$ \\
\hline $\mathrm{O}(3) \mathrm{H}---\mathrm{Cl}(2)$ & $3.0787(19)$ & $168(2)$ \\
\hline $\mathrm{O}(3) \mathrm{H}---\mathrm{Cl}(1)$ & $3.0477(18)$ & $160(3)$ \\
\hline $\mathrm{O}(4) \mathrm{H}---\mathrm{Cl}(2)$ & $3.1030(18)$ & $168(3)$ \\
\hline $\mathrm{O}(5) \mathrm{H}---\mathrm{Cl}(1)$ & $3.1983(18)$ & $173(4)$ \\
\hline $\mathrm{O}(5) \mathrm{H}---\mathrm{Cl}(2)$ & $3.401(2)$ & $137(3)$ \\
\hline
\end{tabular}

Table S13. Representative hydrogen bonding distances, angles, and pi-pi stacking interactions in $\left[\mathrm{U}\left(\mathrm{H}_{2} \mathrm{O}\right)_{4} \mathrm{Cl}_{4}\right] \cdot 2(4-\mathrm{OHPyH} \cdot \mathrm{Cl})(\mathbf{U}-3)$.

\begin{tabular}{|c|c|c|c|c|}
\hline Interaction & $\begin{array}{c}\text { Distance }(\AA) \\
\text { donor-acceptor }\end{array}$ & $\begin{array}{c}\text { Angle }\left(^{\circ}\right) \\
\angle \mathrm{D}-\mathrm{H}---\mathrm{A}\end{array}$ & $\mathrm{C}_{\mathrm{g}}---\mathrm{C}_{\mathrm{g}}$ & $\beta\left(^{\mathbf{o}}\right)$ \\
\hline $\mathrm{N}(2) \mathrm{H}---\mathrm{Cl}(2)$ & $3.395(5)$ & $138(2)$ & - & - \\
\hline $\mathrm{O}(1) \mathrm{H}---\mathrm{Cl}(3)$ & $3.038(4)$ & $156(3)$ & - & - \\
\hline $\mathrm{O}(2) \mathrm{H}---\mathrm{Cl}(2)$ & $3.102(3)$ & $154(2)$ & - & - \\
\hline $\mathrm{O}(3) \mathrm{H}---\mathrm{Cl}(3)$ & $3.104(5)$ & $163(3)$ & - & - \\
\hline $\mathrm{C}_{\mathrm{g} 1---\mathrm{C}_{\mathrm{g} 3}}$ & - & - & $3.698(6)$ & 21.0 \\
\hline $\mathrm{C}_{\mathrm{g} 2}---\mathrm{C}_{\mathrm{g} 3}$ & - & - & $3.642(7)$ & 20.5 \\
\hline
\end{tabular}

Table S14.Representative hydrogen bonding distances, angles, and pi-pi stacking interactions in (4-OHPyH $)_{2} \mathrm{UCl}_{6}$ (U-9).

\begin{tabular}{|c|c|c|c|c|}
\hline Interaction & $\begin{array}{c}\text { Distance }(\AA) \\
\text { donor-acceptor }\end{array}$ & $\begin{array}{c}\text { Angle }\left(^{\circ}\right) \\
\angle \mathrm{D}-\mathrm{H}---\mathrm{A}\end{array}$ & $\mathrm{C}_{\mathrm{g} 1^{---} \mathrm{C}_{\mathrm{g} 1}}$ & $\beta\left(^{\circ}\right)$ \\
\hline $\mathrm{N}(1) \mathrm{H}---\mathrm{Cl}(3)$ & $3.2238(17)$ & $148(2)$ & - & - \\
\hline $\mathrm{O}(1) \mathrm{H}---\mathrm{Cl}(2)$ & $3.2201(16)$ & $157(3)$ & - & - \\
\hline $\mathrm{C}_{\mathrm{g} 1---\mathrm{C}_{\mathrm{g} 1}}$ & - & - & $3.5816(11)$ & 10.5 \\
\hline
\end{tabular}

Table S15. Representative hydrogen bonding distances, angles, and pi-pi stacking interactions in (HPhthal) ${ }_{2} \mathrm{UCl}_{6}$ (U-10).

\begin{tabular}{|c|c|c|c|c|}
\hline Interaction & $\begin{array}{c}\text { Distance }(\AA) \text { donor- } \\
\text { acceptor }\end{array}$ & $\begin{array}{c}\text { Angle }\left(^{\circ}\right) \\
\angle \mathrm{D}-\mathrm{H}---\mathrm{A}\end{array}$ & $\mathrm{C}_{\mathrm{g}}{ }^{---} \mathrm{C}_{\mathrm{g}}$ & $\beta\left(^{\mathrm{o}}\right)$ \\
\hline $\mathrm{N}(1) \mathrm{H}---\mathrm{Cl}(1)$ & $3.201(3)$ & $148(3)$ & - & - \\
\hline $\mathrm{C}_{\mathrm{g} 2^{---} \mathrm{C}_{\mathrm{g} 1}}$ & - & - & $3.8172(9)$ & 28.9 \\
\hline $\mathrm{C}_{\mathrm{g} 2^{---} \mathrm{C}_{\mathrm{g} 2}}$ & - & - & $3.8419(9)$ & 28.9 \\
\hline
\end{tabular}


Table S16. Representative hydrogen bonding distances, angles, and pi-pi stacking interactions in $(3-\mathrm{MePyH})_{2} \mathrm{UCl}_{6}(\mathbf{U}-\mathbf{1 1})$.

\begin{tabular}{|c|c|c|c|c|}
\hline Interaction & $\begin{array}{c}\text { Distance }(\AA) \text { donor- } \\
\text { acceptor }\end{array}$ & $\begin{array}{c}\text { Angle }\left(^{\circ}\right) \\
\angle \mathrm{D}-\mathrm{H}---\mathrm{A}\end{array}$ & $\mathrm{C}_{\mathrm{g} 1}---\mathrm{C}_{\mathrm{g} 1}$ & $\beta\left({ }^{\circ}\right)$ \\
\hline $\mathrm{N}(1) \mathrm{H}---\mathrm{Cl}(1)$ & $3.2075(19)$ & $152(2)$ & - & - \\
\hline $\mathrm{C}_{\mathrm{g} 1--\mathrm{C}_{\mathrm{g} 1}}$ & - & - & $3.7008(12)$ & 23.3 \\
\hline
\end{tabular}

$\underline{\text { Pu compounds }}$

Table S17. Representative hydrogen bonding distances, angles, and pi-pi stacking interactions in $(3-\mathrm{ClPyH})_{2} \mathrm{PuCl}_{6}(\mathbf{P u}-\mathbf{6})$.

\begin{tabular}{|c|c|c|c|c|}
\hline Interaction & $\begin{array}{c}\text { Distance }(\AA) \text { donor- } \\
\text { acceptor }\end{array}$ & $\begin{array}{c}\text { Angle }\left({ }^{\circ}\right) \\
\angle \mathrm{D}-\mathrm{H}---\mathrm{A}\end{array}$ & $\mathrm{C}_{\mathrm{g} 11^{---} \mathrm{C}_{\mathrm{g} 1}}$ & $\beta\left(^{\circ}\right)$ \\
\hline $\mathrm{N}(1) \mathrm{H}---\mathrm{Cl}(2)$ & $3.1653(19)$ & $154(2)$ & - & - \\
\hline $\mathrm{C}_{\mathrm{g} 1---\mathrm{C}_{\mathrm{g} 1}}$ & - & - & $3.4311(7)$ & 18.8 \\
\hline
\end{tabular}

Table S18. Representative hydrogen bonding distances and angles in $\left(\mathrm{H}_{2}\right.$ bipy $) \mathrm{PuCl}_{6}(\mathbf{P u}-7)$.

\begin{tabular}{|c|c|c|}
\hline Interaction & Distance $(\AA)$ donor-acceptor & $\begin{array}{c}\text { Angle }\left({ }^{\circ}\right) \\
\angle \mathrm{D}-\mathrm{H}---\mathrm{A}\end{array}$ \\
\hline $\mathrm{N}(1) \mathrm{H}---\mathrm{Cl}(2)$ & $3.2928(15)$ & $135.8(4)$ \\
\hline
\end{tabular}

Table S19. Representative hydrogen bonding distances and angles, and pi-pi stacking interactions in (4-OHPyH $)_{2} \mathrm{PuCl}_{6}(\mathbf{P u}-9)$.

\begin{tabular}{|c|c|c|c|c|}
\hline Interaction & $\begin{array}{c}\text { Distance }(\AA) \text { donor- } \\
\text { acceptor }\end{array}$ & $\begin{array}{c}\text { Angle }\left(^{\circ}\right) \\
\angle \mathrm{D}-\mathrm{H}---\mathrm{A}\end{array}$ & $\mathrm{C}_{\mathrm{g} 1---\mathrm{C}_{\mathrm{g} 1}}$ & $\beta\left(^{\circ}\right)$ \\
\hline $\mathrm{N}(1) \mathrm{H}---\mathrm{Cl}(1)$ & $3.210(3)$ & $148(3)$ & - & - \\
\hline $\mathrm{O}(1) \mathrm{H}----\mathrm{Cl}(2)$ & $3.306(3)$ & $119(3)$ & - & - \\
\hline $\mathrm{O}(1)----\mathrm{Cl}(3)$ & $3.261(3)$ & $148(3)$ & - & - \\
\hline $\mathrm{C}_{\mathrm{g} 1---\mathrm{C}_{\mathrm{g} 1}}$ & - & - & $3.562(2)$ & 6.9 \\
\hline
\end{tabular}

Table S20. Representative hydrogen bonding distances, angles, and pi-pi stacking interactions in (HPhthal $)_{2} \mathrm{PuCl}_{6}(\mathbf{P u}-10)$.

\begin{tabular}{|c|c|c|c|c|}
\hline Interaction & $\begin{array}{c}\text { Distance }(\AA) \text { donor- } \\
\text { acceptor }\end{array}$ & $\begin{array}{c}\text { Angle }\left(^{\circ}\right) \\
\angle \mathrm{D}-\mathrm{H}---\mathrm{A}\end{array}$ & $\mathrm{C}_{\mathrm{g}}---\mathrm{C}_{\mathrm{g}}$ & $\beta\left(^{\circ}\right)$ \\
\hline $\mathrm{N}(1) \mathrm{H}---\mathrm{Cl}(2)$ & $3.3089(17)$ & $138.4(19)$ & - & - \\
\hline $\mathrm{C}_{\mathrm{g} 1---\mathrm{C}_{\mathrm{g} 2}}$ & - & - & $3.8099(12)$ & 28.6 \\
\hline $\mathrm{C}_{\mathrm{g} 2---\mathrm{C}_{\mathrm{g} 2}}$ & - & - & $3.8275(12)$ & 28.3 \\
\hline
\end{tabular}

Table S21. Representative hydrogen bonding distances, angles, and pi-pi stacking interactions in (3-MePyH $)_{2} \mathrm{PuCl}_{6}$ (Pu-11).

\begin{tabular}{|c|c|c|c|c|}
\hline Interaction & $\begin{array}{c}\text { Distance }(\AA) \text { donor- } \\
\text { acceptor }\end{array}$ & $\begin{array}{c}\text { Angle }\left({ }^{\circ}\right) \\
\angle \mathrm{D}-\mathrm{H}---\mathrm{A}\end{array}$ & $\mathrm{C}_{\mathrm{g}}---\mathrm{C}_{\mathrm{g}}$ & $\beta\left(^{\circ}\right)$ \\
\hline $\mathrm{N}(1) \mathrm{H}---\mathrm{Cl}(1)$ & $3.201(3)$ & $150(2)$ & - & - \\
\hline $\mathrm{C}_{\mathrm{g} 1} 1^{--} \mathrm{C}_{\mathrm{g} 1}$ & - & - & $3.7160(18)$ & 23.5 \\
\hline
\end{tabular}




\section{Optical absorption spectra of $U$ reaction solutions}

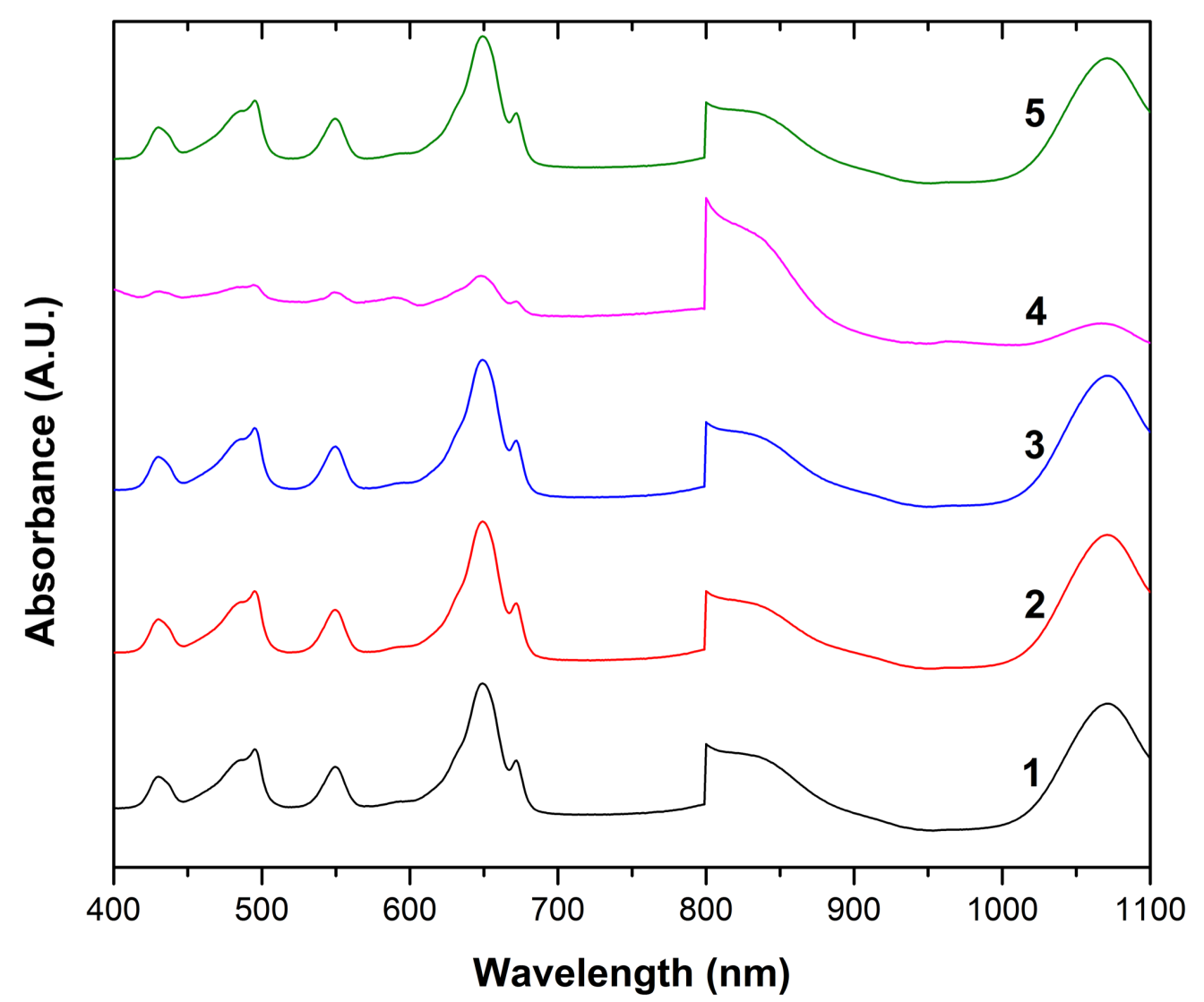

Figure S52. Overlay of UV-vis-NIR spectra of U(IV) reaction solutions for (1) U(IV)/3M HCl with 3-chloropyridine, (2) U(IV)/3M HCl with 4,4'-bipyridine, (3) U(IV)/3M HCl with 4hydroxypyridine, (4) $\mathrm{U}(\mathrm{IV}) / 3 \mathrm{M} \mathrm{HCl}$ with Phthalazine and (5) U(IV)/3M $\mathrm{HCl}$ with 3methylpyridine. The change in absorbance at $800 \mathrm{~nm}$ correlates to an instrumental detector change.

\section{References}

1. Topacli, A.; Akyüz, S. 4,4'-dipyridyl: vibrational assignments and force field. Spectrochimica Acta Part A: Molecular and Biomolecular Spectroscopy 1995, 51, 633641.

2. Denning, R. G., J. O. W. Norris, and D. Brown. The electronic structure of actinyl ions: V. f-f transitions in $\left[\mathrm{NpO}_{2} \mathrm{Cl}_{4}\right]^{2-}$ and $\left[\mathrm{NpO}_{2}\left(\mathrm{NO}_{3}\right)_{3}\right]^{-}$. Molecular Physics 1982, 46, 287323.

3. Schnaars, David D., and Richard E. Wilson. "Structural and Vibrational Properties of $\mathrm{U}(\mathrm{VI}) \mathrm{O}_{2} \mathrm{Cl}_{4}{ }^{2-}$ and $\mathrm{Pu}(\mathrm{VI}) \mathrm{O}_{2} \mathrm{Cl}_{4}{ }^{2-}$ Complexes." Inorg. Chem. 2013, 52, 14138-14147.

4. Jennifer N. Wacker, Monica Vasiliu, Kevin Huang, Ryan E. Baumbach, Jeffery A. Bertke, David A. Dixon, and Karah E. Knope. Uranium(IV) Chloride Complexes: $\mathrm{UCl}_{6}{ }^{2-}$ and an Unprecedented $\mathrm{U}\left(\mathrm{H}_{2} \mathrm{O}\right)_{4} \mathrm{Cl}_{4}$ Structural Unit. Inorg. Chem. 2017, 56, 9772-9780.

5. Miller, F. A., Spectra of $\mathrm{X}-\mathrm{H}$ Systems (with Emphasis on $\mathrm{O}-\mathrm{H}$ and $\mathrm{N}-\mathrm{H}$ Groups). In Course Notes on the Interpretation of Infrared and Raman Spectra; John Wiley \& Sons, Inc., 2004; 163-178. 